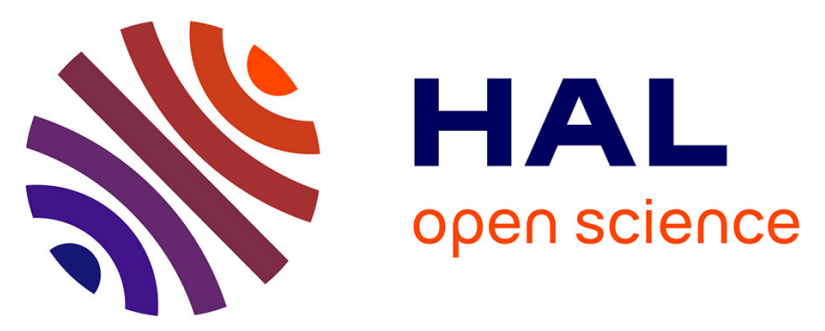

\title{
Integrative taxonomy and biogeography of Asian yellow house bats (Vespertilionidae: Scotophilus) in the Indomalayan Region
}

Vuong Tan Tu, Tamás Görföl, Gabor Csorba, Satoru Arai, Fuka Kikuchi, Dai Fukui, Daisuke Koyabu, Neil Furey, Saw Bawm, Kyaw San Lin, et al.

\section{To cite this version:}

Vuong Tan Tu, Tamás Görföl, Gabor Csorba, Satoru Arai, Fuka Kikuchi, et al.. Integrative taxonomy and biogeography of Asian yellow house bats (Vespertilionidae: Scotophilus) in the Indomalayan Region. Journal of Zoological Systematics and Evolutionary Research, In press, 10.1111/jzs.12448 . hal-03113629

\section{HAL Id: hal-03113629 \\ https://hal.sorbonne-universite.fr/hal-03113629}

Submitted on 18 Jan 2021

HAL is a multi-disciplinary open access archive for the deposit and dissemination of scientific research documents, whether they are published or not. The documents may come from teaching and research institutions in France or abroad, or from public or private research centers.
L'archive ouverte pluridisciplinaire HAL, est destinée au dépôt et à la diffusion de documents scientifiques de niveau recherche, publiés ou non, émanant des établissements d'enseignement et de recherche français ou étrangers, des laboratoires publics ou privés. 
1 Integrative taxonomy and biogeography of Asian yellow house bats (Vespertilionidae:

2 Scotophilus) in the Indomalayan Region

3

4 Vuong Tan $\mathrm{Tu}^{1,2,3,4^{*}}$, Tamás Görfö̈ ${ }^{5,6}$, Gábor $\mathrm{Csorba}^{5}$, Satoru Arai ${ }^{7}$, Fuka Kikuchi ${ }^{7,8,9}$, Dai

5 Fukui $^{10}$, Daisuke Koyabu ${ }^{11,12}$, Neil M. Furey ${ }^{13,14}$, Saw Bawm ${ }^{15}$, Kyaw San Lin ${ }^{15}$, Phillip

6 Alviola $^{16}$, Chu Thi Hang ${ }^{1,2}$, Nguyen Truong Son ${ }^{1,2}$, Tran Anh Tuan ${ }^{1,2}$, and Alexandre

7 Hassanin 3,4

8

9 Institute of Ecology and Biological Resources, Vietnam Academy of Science and Technology,

No. 18, Hoang Quoc Viet Road, Cau Giay District, Hanoi, Vietnam.

11

${ }^{2}$ Graduate University of Science and Technology, Vietnam Academy of Science and

Technology, No. 18, Hoang Quoc Viet Road, Cau Giay District, Hanoi, Vietnam.

14

${ }^{3}$ Institut de Systématique, Évolution, Biodiversité (ISYEB), Sorbonne Université, MNHN,

CNRS, EPHE, UA - Muséum National d'Histoire Naturelle, Paris, France, 55, rue Buffon,

CP51, 75005 Paris, France.

${ }^{4}$ Service de Systématique Moléculaire, UMS 2700, Muséum national d'Histoire naturelle, Case postale $\mathrm{N}^{\circ} 26-43$, rue Cuvier, 75005 Paris, France.

${ }^{5}$ Department of Zoology, Hungarian Natural History Museum, Baross u. 13, Budapest H-1088, Hungary.

${ }^{6}$ National Laboratory of Virology, Szentágothai Research Centre, University of Pécs, Ifjúság útja 20, H-7624 Pécs, Hungary

${ }^{7}$ Infectious Disease Surveillance Center, National Institute of Infectious Diseases, Toyama 123-1, Shinjuku, Tokyo 162-8640, Japan. 

61

${ }^{9}$ Research and Education Center for Prevention of Global Infectious Diseases of Animals, Tokyo University of Agriculture and Technology, 3-5-8 Saiwai, Fuchu, Tokyo 183-8509, Japan.

${ }^{10}$ The University of Tokyo Hokkaido Forest, Graduate School of Agricultural and Life Sciences, The University of Tokyo, Hokkaido 079-1563, Japan.

${ }^{11}$ Jockey Club College of Veterinary Medicine and Life Sciences, City University of Hong Kong, To Yuen Building, Tat Chee Avenue, Kowloon, Hong Kong.

${ }^{12}$ Department of Molecular Craniofacial Embryology, Graduate School of Medical and Dental Sciences, Tokyo Medical and Dental University, 1-5-45 Yushima, Bunkyo-ku, Tokyo 1138549, Japan.

${ }^{13}$ Fauna \& Flora International, Cambodia Programme, No. 19, Street 360, Boeng Keng Kang 1, Chamkarmorn, Phnom Penh, Cambodia.

${ }^{14}$ Harrison Institute, Bowerwood House, No. 15, St Botolph's Road, Sevenoaks, Kent, TN13 $3 \mathrm{AQ}, \mathrm{UK}$.

${ }^{15}$ University of Veterinary Science, Yezin, Nay Pyi Taw 15013, Myanmar.

${ }^{16}$ Institute of Biological Sciences and Museum of Natural History, University of the Philippines Los Banos, Laguna, Philippines.

*Corresponding author

Running title: Integrative taxonomy and biogeography of Asian Scotophilus 
Yellow house bats (Scotophilus) have been known for centuries as a widespread genus of vesper bats in the Indomalayan Region. Despite this, their taxonomic status and phylogeographical patterns remain unclear due to differing criteria employed by early taxonomists and inconsistencies between morphological and molecular assessments. To address these issues, we undertook a comparative phylogeographic analysis of Asian Scotophilus spp. using integrated genetic and morphological analyses of samples collected across the region. These demonstrate that yellow house bats in Asia can be classified into just two widespread species, namely the smaller $S$. kuhlii (e.g., FA $\leq 53.1 \mathrm{~mm}$, GLS $\leq 20.18 \mathrm{~mm}$ ) and the larger $S$. heathii (e.g., FA $\geq 53.4 \mathrm{~mm}, \mathrm{GLS} \geq 20.85 \mathrm{~mm}$ ), which occur in sympatry in different parts of the Indomalayan Region. Although these two sympatric species share similar eco-ethological preferences, they differ considerably in their geographic distributions and intraspecific variation in mtDNA sequences and morphological traits. These disparities were likely misinterpreted as indicating potential cryptic diversity in previous studies, whereas we suggest they are related to interspecific differences in sex-biased gene flow and phenotypic plasticity to adapt to varying environments. Our study highlights the importance of using multiple datasets to resolve taxonomic uncertainties and reconstruct demographic and phylogeographic histories of sympatric species.

83 Keywords: integrative taxonomy, comparative phylogeography, multiple datasets, sympatric species, Scotophilus. 


\section{Introduction}

Species constitute one of the fundamental units of study in many fields of biology. However, the multiplicity of species concepts and criteria used to delineate species boundaries have led to considerable taxonomic confusion and numerous controversies (Aldhebiani, 2018; de Queiroz, 2005, 2007). A typical example of such confusion concerns the systematics of the genus Scotophilus Leach, 1821 (family Vespertilionidae), which comprises yellow house bats that are widely distributed in the Old World tropics.

Until the third edition of Mammal Species of the World (Wilson \& Reeder, 2005), most mammalogists adopted the Biological Species Concept (Mayr, 1942). As such, they usually regarded morphological and ecological variation and/or geographical isolation as indicative of reproductive isolation among sister species and considered that the systematics of mammals were relatively complete and accurate (Baker \& Bradley, 2006). Following taxonomic reviews in the $20^{\text {th }}$ century, Simmons (2005) recognised 12 valid species in the genus Scotophilus, most of which were polytypic and widely distributed in the Old World tropics. Since this time, exploration of poorly studied regions and development of analytical approaches that integrate morphological, molecular and acoustic data have altered taxonomic opinions regarding the utility of different species concepts and associated criteria for delineating species boundaries, including within Scotophilus spp. (Baker \& Bradley, 2006; Demos, Webala, Bartonjo, \& Patterson, 2018; Francis et al., 2010; Trujillo, Patton, Schlitter, \& Bickham, 2009; Vallo \& Van Cakenberghe, 2017). For instance, recent integrative studies have revealed that certain traditionally accepted and polytypic species of Scotophilus in Africa actually comprise several distinct species which were previously unrecognized or subsumed as subspecies due to their morphological similarities. As a consequence, the number of valid African Scotophilus species has increased from eight (Simmons, 2005) to 18 and will likely continue to grow as further cryptic forms of widespread taxa are found (Demos et al., 2018; Trujillo et al., 2009; Vallo, Reeder, Vodzak, \& Benda, 2019; Vallo \& Van Cakenberghe, 2017).

Prior to 1940, Asian Scotophilus included 17 distinct taxa (species and subspecies) (Figure 1; Table S1). Between 1940 and 2000, several studies addressed the taxonomic status of Scotophilus spp. in Asia on the basis of their morphology (Table 1). These led to consensus among early bat taxonomists that two sizes of yellow house bats, small and large, co-occur in 
many parts of the Indomalayan Region (Corbet \& Hill, 1992; Hill \& Thonglongya, 1972; Shamel, 1942; Siddiqi, 1960; Tate, 1942). However, these studies frequently employed differing criteria to interpret morphological variation in their specimen material and consequently applied different taxonomic approaches to the same geographical populations. A typical example of this is apparent in the differences in the systematics of the two yellow house bats present in the Sunda Islands (e.g. Java, Bali, Belitung and Borneo).

Within the Sunda Islands, Tate (1942) included all specimens of yellow house bats collected on Java and nearby islands in three subspecies of $S$. temminckii Horsfield, 1824 (=S. kuhlii Leach, 1821; see Hill \& Thonglongya, 1972): S. t. temminckii, S. t. collinus Sody, 1936 and S. t. solutatus Sody, 1936. In contrast, Shamel (1942) classified the small and large yellow house bats on Java into two distinct species, Pachyotus (=Scotophilus) temminckii and $P$. solutatus, respectively. The taxonomic situation became more complex when Siddiqi (1960) also classified Javanese yellow house bats into two species, the smaller $S$. $t$. temminckii and the larger S. heathii Horsfield, 1831. However, specimens of the larger species and females of the smaller taxon recognized by Siddiqui (1960) were morphologically comparable to those of P. solutatus (sensu Shamel, 1940). Likewise, Corbet \& Hill (1992) allocated Asian Scotophilus into just two polytypic species, namely (1) S. kuhlii, including subspecies/synonyms occurring widely in the Indomalayan Region: castaneus Horsfield, 1851, collinus, consobrinus Allen, 1906, fulvus Gray, 1843, gairdneri Kloss, 1917, panayensis Sody, 1928, solutatus, swinhoei Blyth, 1860, temminckii, and wroughtoni Thomas, 1897; and (2) S. heathii, including the synonyms belangeri Geoffroy I., 1834, flaveolus Horsfield, 1851, insularis Allen, 1906, luteus Blyth, 1851 and watkinsi Sanborn 1952 which were restricted to mainland Asia, plus celebensis Sody, 1928 endemic to Sulawesi. This view ignored the treatments of Shamel (1942) and Siddiqi (1960) in considering all yellow house bats on Java and nearby islands as representatives of S. kuhlii sensu lato (s.1.) and created extensive overlap in the morphology of bats of this taxon (i.e. FA: $45-59 \mathrm{~mm}$ ) and those of $S$. heathii s.l. (i.e. FA $\geq 55 \mathrm{~mm}$ ) (Figure 1; Table 1).

Contrary to earlier treatments (Corbet \& Hill, 1992; Shamel, 1942; Siddiqi, 1960; Tate, 1942), Kitchener, Packer, \& Maryanto (1997) argued that smaller Scotophilus with a FA of less than $54 \mathrm{~mm}$ on the Greater (Java and Borneo) and Lesser Sunda Islands were readily identifiable as two distinct species, namely the smaller $S$. collinus (i.e. mean FA values for males and females: 49.1 and 50.9 respectively) and the larger $S$. kuhlii (i.e. mean FA values 
154 for males and females are 51.8 and 52.5, respectively). Both of these species were further

155 divided into two morphological forms, but only those of the larger species, S. kuhlii s.l. were

156 regarded as two subspecies, namely S. k. temminckii inhabiting West and East Java and its

157 relatively smaller sister $S$. $k$. solutatus, occurring on East Java and Bali. On East Java, two

158 subspecies of $S$. kuhlii were recognised in adjacent mountain ranges separated by the

159 Bondoyudo River plains, and the authors even suggested that they might be distinct species.

160

161

162

In light of the above, the taxonomic status of several subspecies or races of two

163 polytypic species, S. kuhlii s.1. and S. heathii s.l. (sensu Corbet \& Hill, 1992) is likely inaccurate. Many of these taxa were originally described as distinct species or subspecies that were individually distinguished by certain morphological variation (pelage colour or body size) and/or geographical hiatus (Figure 1; Table S1). Nonetheless, Simmons (2005) and subsequent authors (Hutson, Kingston, Francis, \& Suyanto, 2008; Moratelli et al. 2019; Sinaga \& Maryanto, 2008; Srinivasulu \& Srinivasulu, 2019a, 2019b) recognised only four distinct species of Asian Scotophilus: (1) S. kuhlii, found widely in the Indomalayan Region; (2) S. collinus, occurring sporadically in the Greater and Lesser Sunda Islands; (3) S. heathii, found in mainland Asia, except for the southern Indochinese subregion; and (4) S. celebensis, endemic to Sulawesi (Figure 1). Among these, the separation of S. celebensis from S. heathii was regarded as provisional (Simmons, 2005) because it was based solely on the disjunct distributions of the two taxa (Corbet \& Hill, 1992; Tate, 1942).

Recent genetic studies have improved our understanding of the taxonomy and biogeography of Asian yellow house bats (Francis et al., 2010; Hisheh, How, Suyanto, \& Schmitt, 2004; Trujillo et al., 2009; Yu, Chen, Li, \& Wu, 2012). In relation to morphological taxonomy, the separation of the two differently sized species, S. kuhlii and S. heathii, has been highly supported by genetic analyses (Francis et al., 2010; Trujillo et al., 2009). Within $S$. kuhlii s.l., all recent studies have found little genetic differences between geographically

181 distant populations in the Lesser Sunda Islands (Hisheh et al., 2004), from Vietnam,

182 Peninsular Malaysia and the Philippines (Trujillo et al., 2009), from northern and southern

183 Indochina (Laos and Vietnam) (Francis et al., 2010) and from Hainan Island and mainland

184 China (Yu et al., 2012). These data indicate that gene flow across the studied populations of $S$. kuhlii has not been limited by geographical distance or sea-barriers (Hisheh et al., 2004; Yu et al., 2012). While comparable morphological data are still lacking due to inadequate or disparate sampling, it is very likely that $S$. kuhlii represents a monotypic species. For this 
reason, research is needed to confirm the taxonomic validity of species or subspecies that were subsumed into or distinguished from S. kuhlii on the basis of morphology alone.

Compared to S. kuhlii s.1., S. heathii s.1. has similar eco-ethological preferences. However, the latter species may have a greater dispersal ability due to its higher wing loading and aspect ratio e.g. 15 vs 11.6 and 8.0 vs 6.96, respectively (Francis, 2008; Luo et al., 2019; Norberg \& Rayner, 1987; Zhu, Chmura, \& Zhang, 2012). If so, this would suggest that $S$. heathii s.l. could also maintain a strong gene flow between its geographically distant populations. This inference is supported by Trujillo et al. (2009) who analysed genetic divergences in mtDNA (Cytb) and nuDNA (zinc finger Y $-z f y$ gene) sequences between $S$. heathii from Yunnan (China) and northern and southern Vietnam and suggested that these represent the same species. Conversely, Francis et al. (2010) found that $S$. heathii bats from northern Indochina (northern Vietnam and Laos) and southern Indochina (southern Vietnam) constituted two highly divergent clusters of $C O I$ gene sequences. Because comparable $C O I$ divergence exist between many closely related species in the Vespertilioninae, Francis et al. (2010) suggested that Indochinese S. heathii may represent a complex of different species.

However, since mitochondrial data are maternally inherited, they should not be solely used to draw taxonomic conclusions (Dool et al., 2016; Hassanin, An, Ropiquet, Nguyen, \& Couloux, 2013; Nesi, Nakouné, Cruaud, \& Hassanin, 2011; Tu et al., 2017; Tu, Hassanin, Furey, Son, \& Csorba, 2018). For a more integrative approach, the hypothesis of Francis et al. (2010) requires further testing with biparental genetic markers, geographically denser sampling and additional morphological data.

This paper presents a phylogeographic study of Asian Scotophilus based on new specimens obtained from different areas in the Indomalayan Region. To this end, we integrate genetic and morphological analyses to (1) address taxonomic uncertainties (e.g. misidentifications or potential cryptic diversity) regarding Asian yellow house bats; (2) evaluate patterns in the demographic and evolutionary histories of species recognized by this study; and (3) consider the roles of ecological factors in shaping the current distributions, population genetic structures and morphological variation of the species. Our overall aim was to improve understanding of the taxonomy and biogeography of Asian yellow house bats.

\section{Materials and Methods}




\subsection{Taxonomic sampling}

In this study, we examined 106 bats of S. kuhlii s.1. (n=76) and S. heathii s.1. $(\mathrm{n}=30)$ collected from different parts in the Indomalayan Region (Figure 1; Appendix 1). Of which, 97 voucher specimens are held in the Institute of Ecology and Biological Resources (IEBR, Hanoi, Vietnam), the Hungarian Natural History Museum (HNHM, Budapest, Hungary), the Centre for Biodiversity Conservation (CBC, Royal University of Phnom Penh, Cambodia), the University of Tokyo Hokkaido Forest (UTHF, Furano, Hokkaido, Japan), and the University of the Philippines Los Banos Museum of Natural History (UPLB-MNH, Laguna, Philippines) (See Appendix 1). Tissue samples were collected from the chest muscles of voucher specimens or from the patagium (biopsy punches; $3 \mathrm{~mm}$ diameter) of released individuals and preserved in $95 \%$ ethanol and stored at $-20^{\circ} \mathrm{C}$.

We generated 38 Cytb (complete cytochrome b; 1,140 bp) and 43 COI (fragment of cytochrome c oxidase subunit I; 705-1554 bp) sequences from 49 examined individuals encountered during field surveys undertaken by the authors between 2008 and 2019 (30 specimens were sequenced for both mitochondrial genes) (Appendix 1). These newly generated sequences were compared to the $20 C y t b$ and $41 C O I$ sequences available in GenBank for Asian Scotophilus spp. collected from other localities in the Indomalayan Region by other authors (Figure 1; Table S2) to explore their phylogeographic and phylogenetic relationships. We further sequenced two nuclear genes including intron 9 of TUFM (elongation factor Tu, mitochondrial precursor) and intron 6 of ZFYVE27 (zinc finger, FYVE domain containing 27) for six selected specimens of $S$. kuhlii $(\mathrm{n}=2)$ and $S$. heathii $(n=4)$ to test any incongruence between mitochondrial and nuclear DNA phylogenies. Based on previous studies (Roehrs, Lack, \& Van Den Bussche, 2010; Trujillo et al., 2009), Murina cyclotis Dobson, 1872 of the subfamily Murininae and Eptesicus pachyomus Dobson, 1871 of the subfamily Vespertilioninae were chosen as outgroups in phylogenetic analyses. Genetic sequences available for these outgroup species in GenBank are indicated in Table S2. 
Total DNA was extracted from tissue samples using the QIAGEN DNAeasy Tissue Kit (Qiagen, Hilden, Germany) according to the manufacturer's protocol. Primer sets used for PCR amplification of Cytb were Mt-14724F/Cyb-15915R (Irwin, Kocher, \& Wilson, 1991), Cyb-14726F/Cyb-15909R (Arai et al., 2016) and for COI were UTyrLA/C1L 705 (Hassanin et al., 2012) or MammMt-5533F/MammMt-7159R (Arai et al., 2019) and for TUFM and ZFYVE27 were TUFM-EX9U/TUFM-EX10L and ZFYVE27-EX6U/ZFYVE27-EX7L, respectively (Hassanin et al. 2013) (See Table S3 for more details).

Amplifications were done in a volume of $20 \mu \mathrm{l}$ including $3 \mu \mathrm{l}$ of Buffer 10X with $\mathrm{MgCl}_{2}, 2 \mu \mathrm{l}$ of dNTP $(6.6 \mathrm{mM}), 0.12 \mu \mathrm{l}$ of Taq DNA polymerase (2.5 U, Qiagen, Hilden, Germany) and $0.5-1 \mu \mathrm{l}$ of the two primers at $10 \mu \mathrm{M}$. The standard PCR conditions were as follows: $4 \mathrm{~min}$ at $95^{\circ} \mathrm{C} ; 5$ cycles of denaturation/annealing/extension with $45 \mathrm{~s}$ at $95^{\circ} \mathrm{C}, 1 \mathrm{~min}$ at $60^{\circ} \mathrm{C}$ and $1 \mathrm{~min}$ at $72^{\circ} \mathrm{C}$, followed by 30 cycles of $30 \mathrm{~s}$ at $95^{\circ} \mathrm{C}, 45 \mathrm{~s}$ at $55^{\circ} \mathrm{C}$, and $1 \mathrm{~min}$ at $72^{\circ} \mathrm{C}$, followed by $10 \mathrm{~min}$ at $72^{\circ} \mathrm{C}$. PCR products were resolved by electrophoresis on a $1.5 \%$ agarose gel stained with ethidium bromide and visualized under UV light.

Both strands of PCR products were sequenced using Sanger sequencing on an ABI 3730 automatic sequencer at the Centre National de Séquençage (Genoscope) in Evry (France) and ABI 3730x1 DNA Analyzer at the Infectious Disease Surveillance Center, Japan. The sequences were edited and assembled using CodonCode Aligner Version 3.7.1 (CodonCode Corporation) and Genetyx v11 software (Genetyx Corporation, Japan). Heterozygous positions (double peaks) of nuclear gene sequences were scored using the IUPAC ambiguity codes. Sequences generated for this study were deposited in the EMBL/DDBJ/GenBank database under the accession numbers MT820574-MT820611, MT820613-MT820624, MT820574-MT820611 (Appendix 1).

\section{Phylogeographic analyses using mtDNA sequences}

The number of haplotypes, haplotype diversity (h), and nucleotide diversity $(\pi)$ for the two nominal species, $S$. kuhlii s.1. and S. heathii s.1., were calculated from the alignments of 82 COI (576 bp) and 58 Cytb (1140 bp) sequences (Alignments S1 and S2) using DNASP v5.10 (Librado \& Rozas, 2009). Maximum parsimony haplotype networks were reconstructed using the TCS algorithm in PopArt (Leigh \& Bryant, 2015). Following this, a hierarchical analysis of molecular variation (AMOVA) (Excoffier, Smouse \& Quattro, 1992) was 
performed with 1,000 permutations in Genodive v.3.0 (Meirmans \& Tienderen, 2004) to quantify the genetic variation within and among groups in the TCS network.

\section{Phylogenetic reconstruction}

Phylogenetic trees of Asian Scotophilus spp. were reconstructed from DNA alignments (Alignments S3-S7) using Bayesian Inference (BI) and Maximum-Likelihood (ML) methods. DNA sequences were aligned with Aliview v. 1.25 (Larsson, 2014). No gaps and stop codons were found in the alignments of the mitochondrial COI and Cytb proteincoding genes. In contrast, a few gaps were included in the alignments of the nuclear genes, but their positions were not ambiguous. The indels (insertion or deletion) shared by at least two taxa in the alignments of each nuclear gene were coded as additional characters ("1": insertion; "0": deletion) and analysed as a separate partition in the Bayesian analyses. The models of nucleotide evolution were selected under jModelTest V. 2.1.7 (Posada, 2008) using the Akaike Information Criterion (AIC): GTR $+\mathrm{G}$ for $C O I$ dataset, $\mathrm{GTR}+\mathrm{I}$ for $C y t b$ dataset, and HKY model for TUFM and ZFYVE27 datasets. The BI analyses were conducted with MrBayes v. 3.2.5 (Ronquist et al., 2012) using five separate datasets: (1) COI (48 sequences; 657 bp), (2) Cytb (39 sequences; 1140 bp), (3) TUFM (642 bp and 10 indels; 8 sequences), ZFYVE27 (734 bp and 7 indel; 8 sequences) and (5) nuDNA (combining two nuclear genes; 1376 bp and 17 indels, 8 sequences) (Alignments S3-S7). The posterior probabilities (PP) were calculated using four independent Markov chains run for $10^{7}$ Metropolis-coupled MCMC generations, with trees sampled every 1000 generations and a burn-in of $25 \%$. The ML analyses of COI, Cytb, and nuDNA datasets (Alignments S3, S4, and S7) were conducted with W-IQ-TREE tool available online (http://iqtree.cibiv.univie.ac.at/) (Hoang et al., 2018; Nguyen et al., 2015; Trifinopoulos et al., 2016) with 1,000 ultrafast bootstrap replicates. Pairwise genetic distances between divergent phylogenetic lineages or TCS clusters were calculated with PAUP* v. $4 \mathrm{~b} 10$ (Swofford, 2003) using the uncorrected p-distance.

\section{Isolation by distance (IBD)}

$$
\text { Geographic distances }(\mathrm{km}) \text { between geographic haplogroups of } S \text {. kuhlii s.l. and } S \text {. }
$$
heathii s.l. were generated using Geographic Distance Matrix Generator v.1.2.3 (Ersts, 2020). We tested for correlations between pairwise mtDNA distances (minimum p- distance) and geographic distances with the Mantel test (Mantel, 1967) using the generalized linear model 
in PAST 3.07 (Hammer, Harper, \& Ryan, 2001). We also tested for correlations between pairwise genetic distance $\left(\mathrm{F}_{\mathrm{ST}} /\left(1-\mathrm{F}_{\mathrm{ST}}\right)\right.$ and geographic distance $(\mathrm{ln} \mathrm{km})$ for three geographic haplogroups of $S$. heathii identified in the COI network.

\section{Historical demography}

The dynamics of effective female population size within S. kuhlii s.l. and S. heathii s.l. were estimated from the Bayesian skyline plot (BSP) method in BEAST v.2.5.2 (Bouckaert et al., 2019) using COI datasets (Alignment S1). As no calibration point (fossil record or biogeographic event) was available for Scotophilus, we used a mutation rate of $2 \times 10^{-8}$ per site per million years for the COI gene based on previous studies (i.e. Tu et al. 2017; Mao et al. 2010). The model of evolution of COI dataset was selected by jModelTest. We ran a MCMC chain of 20 million generations, sampled every 1000 generations and a burn-in of $10 \%$ with uncorrelated lognormal relaxed molecular clock. Tracer v.1.6 (available in the BEAST package) was used to assess the adequacy of chain mixing and MCMC chain convergence using ESS values of $>200$ and to visualize the Bayesian skyline plots.

\subsection{Morphological analyses}

\section{Morphological comparison}

Ninety-seven Scotophilus specimens listed in the Appendix 1 were included in our morphological analyses. All of the specimens examined were adults, as confirmed by the presence of fully ossified metacarpal-phalangeal joints.

External measurements were taken to the nearest $0.1 \mathrm{~mm}$ from alcohol-preserved specimens. These included: FA — length of forearm, Tib - tibia length, from the knee joint to the ankle. Craniodental measurements were taken to the nearest $0.01 \mathrm{~mm}$ using digital calipers under a stereomicroscope. These included: GSL - total length of skull, from the most anterior part of the upper incisors to the occiput; SL-greatest length of skull, the anterior rim of the alveolus of the $1^{\text {st }}$ upper incisor to the most posteriorly projecting point of the occipital region; $\mathrm{CBL}$ - condylobasal length, from the occipital condyles to the anterior of the alveolus of the $1^{\text {st }}$ upper incisor; CCL — condylo-canine length, from the exoccipital condyle to the most anterior part of the canine; ZB_-greatest width of the skull across the zygomatic arches; 
$\mathrm{C}^{1} \mathrm{C}^{1}$ — greatest width across the upper canines between their buccal borders; $\mathrm{M}^{3} \mathrm{M}^{3}$ - greatest width across the crowns of the last upper molars; $\mathrm{CM}^{3}$ - maxillary toothrow length, from the anterior of the upper canine to the posterior of the crown of the $3^{\text {rd }}$ upper molar; ML-length of mandible, from the anterior rim of the alveolus of the first lower incisor to the most posterior part of the condyle; and $\mathrm{CM}_{3}$ - mandibular toothrow length, from the anterior of the lower canine to the posterior of the crown of the $3^{\text {rd }}$ lower molar.

In this study, we initially assigned our study specimens to different groups based on molecular data. Specimens lacking genetic information were classified into molecular groups according to their geographic origin (Figure 1). As specimens examined within these groups lacked sexual dimorphism in all external and craniodental measurements (T-test, $p>0.05$ ), the phenetic affinity of the identified taxa with both sexes combined was inferred through univariate and multivariate analyses of their morphometrics. Principal Component Analysis (PCA) of study specimens was undertaken in PAST 3.07 (Hammer et al, 2001) using 10 logtransformed craniodental measurements. Equalities of mean values of morphometrics and PC scores among different taxa were tested using a one-way analysis of variance (ANOVA), followed by a post-hoc Tukey HSD multiple comparison test for unequal sample sizes (Tukey-Kramer) (Zar, 1999).

\section{RESULTS}

\subsection{Genetic analyses}

\subsubsection{Phylogeographic patterns of Asian Scotophilus inferred from mtDNA sequences}

In the COI alignment (576 bp), 22 haplotypes were identified among 43 individuals of S. kuhlii s.1., and 18 haplotypes among 39 individuals of $S$. heathii s.1.. In the Cytb alignment (1,140 bp), 27 haplotypes were identified among 46 bats of $S$. kuhlii s.l. and seven among 12 bats of S. heathii s.1. (Figure 1; Appendix 1; Table S2). Haplotype (Hd) and nucleotide diversities $(\pi)$ calculated from $C O I$ and $C y t b$ alignments for the entire populations of each taxon were high i.e. $>0.86$ and $>0.01$, respectively (Table S4). In both species, most individuals examined, even those from the same locations, carried unique COI or Cytb haplotypes. 

"bush-like" shape without ancestral haplotype (Figure 1). However, mtDNA haplotypes derived from geographically distant populations of $S$. kuhlii s.l. were found to be intermixed or identical, whereas those of $S$. heathii s.l. displayed geographical patterns. For instance, the COI TCS network shows the separation of three clusters of haplotypes derived from individuals of $S$. heathii s.l. collected in: (1) Indian Subcontinent, including those collected from locations 1-3 in Pakistan and location 4 in India; (2) southern Indochina, including those found from locations 16-21; and (3) northern Indochina, including samples found from locations 9-12. AMOVA analyses revealed that pairwise genetic distances (Fst) among these three clusters were between 0.11-0.433 and significant (Table S5). Likewise, in the Cytb TCS network, the private haplotypes found in three geographic areas (Yunnan (China), northern and southern Vietnam (or Indochina) were also separated (Figure 1).

Consistent with the observed divergences in phylogeographic patterns between the two species, Mantel tests (Figure S1A) showed a lack of statistically significant correlations between pairwise mtDNA and geographic distances in $S$. kuhlii s.l. (correlation $\mathrm{R}^{2}<0.3$ ) and the opposite in $S$. heathii s.1. $\left(\mathrm{R}^{2} \geq 0.66\right)$ (Figure S1A). Similarly, the genetic differentiation among three geographic haplotype clusters of the latter taxon obtained from COI network analysis largely resulted from IBD effects (Table S5; Figure S1B).

\subsubsection{Phylogeny of the Asian Scotophilus inferred from $m t D N A$ sequences}

The phylogenetic trees reconstructed from the alignments of mtDNA genes (COI and

$414 C y t b)$ are depicted in Figures 2 and S2. The genus Scotophilus and the two species S. kuhlii s.l. and S. heathii s.l. were monophyletic in all phylogenetic analyses with maximal support $(\mathrm{PP} / \mathrm{BP}=1 / 100)$. Interspecific distances (uncorrected p-distance) calculated from $C O I$ and $C y t b$ datasets between these nominal species were $\geq 13.9 \%$ and $\geq 14.5 \%$ respectively (Table 2 ).

Within S. kuhlii s.1., all COI and Cytb trees included bats from different geographic areas or subunits of the Indomalayan Region i.e. (1) India and Myanmar, (2) Indochina

421 (Cambodia, Laos, Vietnam) and southern China, (3) Peninsular Malaysia, and (4) the 422 Philippines intertwined with a maximum intraspecific genetic divergence (p-distance) calculated from $C O I$ and $C y t b$ sequences of $\leq 2.3 \%$ (Figures $2 \mathrm{a}-\mathrm{b}$ and $\mathrm{S} 2$; Table 2). 
Within S. heathii s.1., our COI trees (Figures 2a and S2) recovered four lineages, A, B,

426 C, and D. Haplotypes from southern Indochina appeared in lineages A (comprising those 427 collected from locations No. 16, 17, 19, 20 and 21 in Figure 1) and B (those collected from 428 location No. 18 in Figure 1), whereas haplotypes from northern Indochina and the Indian 429 Subcontinental (India and Pakistan) formed two sister lineages, C and D respectively. The 430 range of pairwise p-distances estimated from COI sequences between lineages A and B were $431 \quad 1.1-2.3 \%, 2.6-4.0 \%$ between $\mathrm{C}$ and $\mathrm{A}+\mathrm{B}, 5.1-7.1 \%$ between $\mathrm{C}$ and $\mathrm{D}$, and $5.2-7.6 \%$ between $432 \mathrm{~A}+\mathrm{B}$ and $\mathrm{D}$. The maximum intraspecific variation within these lineages (i.e. lineage $\mathrm{A}$ ) was $433 \leq 1.6 \%$ (Table 2). Likewise, in our $C y t b$ tree (Figures $2 \mathrm{~b}$ and S2), a single individual from 434 Yunnan (China) occupied a basal position to a clade (PP/BP=1/93) united by two well435 supported sister lineages, one containing haplotypes in northern Vietnam (=lineage C; Figure 436 2a) and the other containing haplotypes from southern Vietnam (=lineage A; Figure 2a ) $437(\mathrm{PP} / \mathrm{BP}=1 / 97-100)$. The range of $\mathrm{p}$-distances calculated from $C y t b$ sequences between these 438 three lineages was 3.7-4.2\%, whereas those within populations in northern and southern 439 Vietnam were $\leq 1 \%$ (Table 2).

\subsubsection{Phylogeny of Indochinese Scotophilus based on nuDNA sequence analyses}

Bayesian trees reconstructed from three nuDNA datasets i.e. TUFM, ZFYVE27 and concatenation of the two nuDNA introns from selected individuals of $S$. kuhlii and $S$. heathii from the northern and southern Indochinese geographical units, as revealed by analyses of mtDNA sequences, are presented in Figures 2c, S2 and S3, respectively. Consistent with mtDNA trees, the nuDNA trees supported the monophyly of Scotophilus and the two nominal species, $S$. kuhlii and $S$. heathii, with maximum robustness ( $\mathrm{PP} / \mathrm{BP}=1)$. More specifically, in the TUFM and ZFYVE27 sequence alignments, all Scotophilus bats examined shared a total of 8 and 3 indels respectively, whereas $S$. kuhlii and $S$. heathii were diagnosed by several indels (Figure 2c). Likewise, and inconsistent with mtDNA trees, the substructure of geographical populations in $S$. heathii were not recovered in our analyses of separated or combined nuDNA sequences (Figures 2c and S2). The genetic distances calculated from concatenation of the two nuclear introns (i.e. the p-distances) between $S$. kuhlii and S. heathii ranged between 1.4 and $1.6 \%$, whereas the nuDNA sequences of selected bats of both species from different geographical units were identical (p-distances $<0.1 \%$ ) (Table 2).

\subsection{Historical demography}



and $S$. heathii have maintained their long-term stability since the Mid-Late Pleistocene (ca. 1.5-0.5 million years ago (Mya) and experienced rapid expansion since ca. 0.3 Mya (Late Pleistocene). However, since 0.1 Mya of the late Pleistocene, the total effective population size of S. kuhlii was always larger than S. heathii (Figure S4).

\subsection{Morphological analyses}

467

Asian Scotophilus are relatively large vespertilionids which share similar morphological characteristics: i.e. moderately-sized ears; tragus very long and narrow, tapering slightly towards tip and curving forwards; skulls thick and heavily-built, with just one pair of large, well-developed upper incisors; dental formula I1/3, C1/1, P1/2, M3/3 (Figures 3 and 4) (Corbet \& Hill, 1992; Dobson, 1875; Tate, 1942).

Both univariate and multivariate analyses of morphological characters revealed a large individual originally identified as S. kuhlii from Java (Indonesia) (HNHM 2869.22) as an extreme outlier, distantly related to other specimens of $S$. kuhlii sensu stricto (s.s.) but resembled our specimens of $S$. heathii s.s. (Figure 5; Table 3). As genetic data were not available and its external and craniodental characters matched those of $S$. ? solutatus s.s. (sensu Tate, 1942; Shamel, 1942), this Javanese specimen was treated as a separate taxon in subsequent analyses. Accordingly, S. kuhlii s.s. differs from $S$. heathii s.s. in its smaller body and skull size: i.e. FA: 45.7-53.1 vs 54.3-66.0 mm and GSL: 18.30-20.18 vs 20.85-25.20 $\mathrm{mm}$ (Table 3; Figure 5; Table S6). Aside from the presence of a well-developed occipital helmet in S. heathii s.s., the skull morphology of both species is similar (Figure 4; Table 3). As shown in Figure 3, species identification of Asian yellow house bats based solely on pelage colour should be cautiously interpreted due to geographical variation. Although pelage colour is useful for distinguishing taxa living in sympatry, the reliability of this trait seems doubtful for comparing specimens from different countries, and it is entirely inaccurate for museum specimens due to fading of colour during preservation.

Within S. kuhlii s.s., specimens from mainland Asia (India, Myanmar, Indochina, Peninsular Malaysia) and the Philippines overlapped significantly in body and skull size (Figure 5; Table 3). Likewise, within S. heathii s.s., separation between specimens initially 
allocated to different mtDNA lineages was lacking, although local differentiations were

494 recovered in phenotypes among bats of pairwise geographic populations, even at fine scales

495 (Figure 5; Table 3). For instance, bats of S. heathii s.s. in southern Indochina appeared in 496 three different morphological subgroups according to body and skull size i.e. with a FA of 49754.3 to $66.0 \mathrm{~mm}$ or a GSL of 20.85 to $25.20 \mathrm{~mm}$, respectively (ANOVA, $\mathrm{p} \leq 0.05$; Table S7): 498 (1) smaller bats in south-central Vietnam (location No. 21 and adjacent area, Figure 1); (2) 499 intermediate bats in north-eastern Cambodia (location No. 18, Figure 1); and (3) larger bats in 500 the central highlands of Vietnam (location No. 19, Figure 1) (Figure 5). Similarly, in the PCA 501 of craniodental characters (Figure 5), S. heathii s.s. bats in the Indian Subcontinent and southern Indochina were separated by PC2 which is significantly correlated with the greatest width across the upper canines $\left(\mathrm{C}^{1} \mathrm{C}^{1}\right)$ (Table $\left.\mathrm{S} 6\right)$.

\section{Discussion}

\subsection{Cryptic diversity or inadequate taxonomy?}

Early taxonomists differed considerably in how they delineated species boundaries between taxa allocated to $S$. kuhlii s.1. and S. heathii s.1. (sensu Corbet \& Hill, 1992) in the Indomalayan Region, especially those found on the Sunda Islands (Table 1). According to our integrated analyses, S. kuhlii s.s. and S. heathii s.s. are genetically and morphologically distinct species. The former species is monotypic whereas the latter one is likely polytypic. In particular, FA — a standard measurement with low variation among bat researchers - appears to be reliable for differentiating the two species, as indicated by our PCAs on craniodental traits (Figures 5 and S5). Pairwise comparisons of FA data in different studies (Figure 6) show that apart from some larger individuals in Java and nearby islands (Belitung and Borneo), all other bats assigned to $S$. kuhlii s.l. in the Indomalayan Region are morphologically comparable to our $S$. kuhlii s.s. (i.e. FA $\leq 53.1 \mathrm{~mm}$ ). This includes $S$. collinus (sensu Kitchener et al., 1997) which we regarded as a member of S. kuhlii in agreement with previous authors (e.g. Corbet \& Hill, 1992; Shamel, 1942; Tate, 1942). Regarding the larger specimens of $S$. kuhlii s.1. (i.e. FA $\geq 53.4 \mathrm{~mm}$ ) from Java, Belitung and Borneo, some were identified as S. k. temminckii in past studies (Kitchener et al., 1997; Siddiqi, 1960; Sody, 1928, 1936), whereas others were identified as S. k. collinus and S. k. solutatus (Sody, 1936; Tate, 1942). These controversial specimens and those of $S$. heathii s.1. in mainland Asia and 
Tate, 1942), and P. solutatus (=S. solutatus) in Java (Indonesia) (Shamel, 1942) are comparable to our specimens of $S$. ? solutatus s.s. and $S$. heathii s.s. (Figure 6; Tables 1 and 3). The new evidence from our study suggests that the current taxonomy of Asian Scotophilus spp. (i.e. Moratelli et al. 2019; Simmons, 2005) is inaccurate.

Kitchener et al. (1997) assigned yellow house bats with forearm lengths of $\leq 54 \mathrm{~mm}$ from the Sunda Islands to either $S$. collinus s.s. or $S$. kuhlii s.s. depending on body size i.e. the mean FA values for males / females of each taxon were 49.1 / 50.9 and 51.8 / 52.5, respectively. Their a priori species identifications were then checked by multiple regressions and discriminant function analyses (DFAs) of morphological characters. However, certain issues render the classification of Kitchener et al. (1997) unconvincing. For instance, our pairwise comparison of FA values among the taxa recognised by different authors (Figure 6) reveals that their assumption of the upper limit in forearm length for S. kuhlii s.l. was unjustified and that their study materials may have contained misidentified individuals of a larger form (or S. heathii s.s / S. ? solutatus). Our study and previous taxonomic works (i.e. Hill \& Thonglongya, 1972; Shamel, 1942; Tate, 1942) have also confirmed the existence of individual variation in size and pelage among bats of the same Scotophilus species found in either sympatry or allopatry. As a consequence, the initial species identification of specimens by Kitchener et al. (1997) was uncertain particularly when considering the extensive overlap in all morphometrics given for their recognised taxa with pooled geographic populations i.e. the range of FA values for males / females of each taxon were 44.6-51.9 / 45.2-52.8 and 50.5-54.0 / 50.3-53.7, respectively. In addition to potential misidentification of specimens assigned a priori, the sample sizes of these taxa were heavily skewed in the two DFAs of Kitchener et al. (1997) which set apart two putative taxa (i.e. the datasets for males and females of S. collinus / S. kuhlii were 82 / 10 and 124 / 8, respectively). As such imbalanced datasets tend to produce unsatisfactory classifiers, the classification of a priori taxa in these DFAs should be considered doubtful, even if statistically significant (López, Fernández, García, Palade, \& Herrera, 2013). Consistent with this, separation between the two a priori taxa was not recovered in their DFA of skull characters of both sexes combined (as there is no sexually dimorphic effects on size) using another simulated dataset for S. collinus / S. kuhlii (i.e. 178 / 19 respectively). In particular, Hisheh et al. (2004) considered that S. kuhlii s.l. bats throughout the Lesser Sunda Islands can be treated as a panmictic unit. According to Kitchener et al. (1997), the study area of Hisheh et al. (2004) encompasses two sister species which overlap in size, S. $k$. solutatus and S. collinus, i.e. FA values (in mm) of their males / 
561 females are 50.3-52.4 / 50.5-52.9 and 44.6-51.9/46.4-52.8, respectively. This evidence 562 suggests that the classification of different cryptic species within S. kuhlii s.l. in the Sunda 563 Islands by Kitchener et al. (1997) reflected only artificial groups of a single species which 564 resemble our S. kuhlii s.s.. The latter taxonomic inference is supported by the high overlap in 565 FA values between different putative species determined by Kitchener et al. (1997) and our $S$. $566 k$ khlii s.s. (Figure 6). Moreover, from a biogeographical viewpoint, geographical distance 567 and/or marine straits between the Lesser Sunda Islands (=study areas of Hisheh et al. (2004)) 568 and other parts in the Indomalayan Region (our study) (Figure 1) cannot be considered as a 569 reliable barrier to long-range dispersal and associated gene flow within this species (Hisheh et 570 al., 2004; Yu et al., 2012; this study).

Based on COI distances of $>2 \%$, Francis et al. (2010) suggested that two cryptic 573 species may be recognized in S. heathii, one from northern Indochina (haplotype C-h7 in 574 Figure 2a) and the other from southern Indochina (haplotypes A-h11, h14, h15, and h17 in 575 Figure 2a). Our phylogeographic analyses of $C O I$ sequences from a wider taxonomic sampling (including specimens from Cambodia and Vietnam) do not support this view. For instance, our haplotypes from Indochina fall into three lineages (i.e. A, B and C) (Figures 2a and S2). However, the pairwise p-distances calculated from COI sequences between these lineages ranged between $1.1-4.0 \%$ and overlapped with their intraspecific variation (i.e. lineages A: 0-1.6\%) (Table 2). In particular, the interspecific divergences between our Indochinese lineages (A, B and C) were not supported by either nuDNA or morphological analyses (Figures 2c, S2 and 5; Table 2). This is consistent with the results of Trujillo et al. (2009), in which S. heathii bats from Yunnan (southern China), northern Vietnam and southern Vietnam have identical zfy gene sequences, whereas they belong to three divergent Cytb haplogroups (p-distances: 3.7-4.2\%) (Figures 2b and S2; Table 2). Indeed, the absence of structured signals in nuclear datasets may be a consequence of low mutation rates or incomplete lineage sorting of these loci (i.e. Hassanin et al. 2013). However, the mito-nuclear discordance of $S$. heathii may be best explained by female philopatry and male biased dispersers (Arnold \& Wilkinson, 2015; Rivers, Butlin, \& Altringham, 2005; Tu et al., 2017). As such, the hypothesis of potential cryptic diversity within Indochinese $S$. heathii s.l. can be ruled out. Similarly, the relatively higher genetic divergence of $C O I$ sequences among two morphologically overlapping populations of $S$. heathii s.l. in spatially distant subregions

593 (Indochina lineages A, B, and C and the Indian Subcontinent lineage D (5.1-7.6\% p594 distances) (Figures 1-3 and S2; Table 2)) might also be attributable to their potential sex- 
600

601

602

603

604

605

606

607

608

609

610

611

612

613

614

615

616

617

618

619

620

621

622

623

624

625

626

627

628

biased gene flow followed by IBD effects (Figure S1). Thus, while further analyses of samples from the intervening zones (Nabhan \& Sarkar, 2012; Zwickl \& Hillis, 2002) and/or nuclear markers are needed, the possibility that allopatric speciation events have occurred without morphological changes in the above populations of $S$. heathii s.s. (Bickford et al., 2007; Tu et al., 2017, 2018) would seem very unlikely.

All larger forms of yellow house bats on Java and nearby islands (i.e. FA values of $\geq 53.4 \mathrm{~mm}$ and GSL $\geq 20.5 \mathrm{~mm}$ ) were previously referred to as $S$. kuhlii (Corbet \& Hill, 1992; Simmons, 2005). However, their taxonomic identity was an issue of debate for many years (Figure 6; Table 1). Having examined one of these controversial specimens from Java (HNHM 2869.22), our results suggest that it resembles $S$. heathii s.s. more than S. kuhlii s.s. (Figures 4-6; Table 3). This specimen was collected by the Novara Expedition (1857-1859) and its identity was determined by the British zoologist, Oldfield Thomas (1858-1929). It should be noted that before Hill \& Thonglongya (1972) confirmed that S. kuhlii should replace $S$. temminckii as the correct name for smaller Asian yellow house bats, S. kuhlii was used for larger bats by several taxonomists (Allen, 1906; Osgood, 1932; Shamel, 1942; Thomas, 1897) instead of $S$. heathii which other authors used (Siddiqi, 1960; Tate, 1942) (Table 1). This suggests that the previous allocation of our examined specimen (and $S$. ? solutatus s.s.) and the larger Scotophilus from Java and nearby islands (i.e. Borneo) as $S$. kuhlii s.1. (sensu Corbet \& Hill, 1992; Simmons, 2005; Kitchener et al., 1997; Tate, 1942) was misguided. In addition, while research on Asian bats has intensified in recent years, most survey effort has focused on habitats such as tropical forests which support high bat diversity (Kingston, 2010), whereas bats that live commensally with humans are comparatively neglected (Jung \& Threlfall, 2016). Scotophilus spp. are one of the most common bats in urban-rural habitats but roost in high shelters (e.g. roofs of houses) and forage in open spaces above the effective range of ground-based live-traps (i.e. mist-nets and harp traps) (Bates \& Harrison, 1997; Francis, 2008; Hisheh et al., 2004). As such, they are likely under-surveyed in many regions of Southeast Asia (Figure 1). Consequently, the disjunct distribution of large yellow house bats between mainland Asia (or $S$. heathii s.s.) and Sulawesi (S. celebensis s.s.) (Figure 1) determined by previous authors (e.g. Corbet \& Hill, 1992; Simmons, 2005; Tate, 1942) may be due to erroneous naming of voucher specimens and gaps in survey coverage. Alternatively, the separation of S. celebensis from S. heathii by Simmons (2005) could be regarded as unsubstantiated. Thus, until additional analyses further elucidate their phylogenetic relationships, all large yellow house bats (i.e. FA $\geq 53.4 \mathrm{~mm}$ and GSL $\geq 20.5 \mathrm{~mm}$ 
629 (Figure 6; Tables 1 and 3) occurring in mainland Asia (S. heathii s.s.), Java and nearby islands 630 (S. ? solutatus), and Sulawesi (S. celebensis s.s.) should be regarded as representatives of a 631 single species: $S$. heathii.

4.2. Comparative phylogeography of Asian Scotophilus spp.

The absence of star-like TCS haplotype networks (Figure 1) and results of BSP analyses (Figure S4) in our study indicate that both S. kuhlii and S. heathii have maintained a constant or expanding effective population size through time since the Mid-Pleistocene. The distribution and lack of bottlenecks in the evolutionary history of Asian yellow house bats in the Indomalayan Region thus differs strikingly from other co-distributed bat species i.e. bamboo bats (Tylonycteris spp.) (Tu et al., 2017), woolly bats (Kerivoula spp.) (Khan et al., 2010; Tu et al., 2018), horseshoe bats (Rhinolophus spp.) (Mao et al., 2010). This may be attributable to eco-ethological differences (Avise, 2000; Hassanin et al., 2016; Moussy et al., 2013). For example, Asian yellow house bats are strong dispersers and aerial-hawking, open space foragers (Bates \& Harrison, 1997; Francis, 2008; Norberg \& Rayner, 1987), whereas Tylonycteris, Kerivoula and Rhinolophus spp. have a much weaker dispersal ability because they are mostly forest-dwelling taxa (Khan et al., 2010; Mao et al., 2010; Tu et al., 2017; 2018). Thus, unlike forest-dependent species, the dispersal and associated gene flow among geographic populations of Asian Scotophilus might be less restricted by physical and ecological barriers (Hisheh et al., 2004; Yu et al., 2012). In addition, while the population structure and dynamics of species with low dispersal capacities were strongly influenced by the past compression and expansion of forests during glacial and interglacial periods in the Pleistocene (Khan et al., 2010; Mao et al., 2010; Tu et al., 2017; 2018) and by current patterns of deforestation (Kingston, 2010), Asian Scotophilus spp. may have been less affected by such changes.

Our comparative phylogeographic analyses show that geographically distant populations of S. kuhlii in the Indomalayan Region possess very low genetic and morphological variation, whereas those of $S$. heathii in mainland Asia display divergent mtDNA sequences and phenotypes (see section 4.1 for more detail). As discussed above, the incongruences in phylogeographic patterns of mtDNA genetic diversity between the two sympatric species may be attributable to sex-biased gene flows (Avise, 2000; Slatkin, 1987). More specifically, the phylogenetic signals in our mtDNA and nuDNA datasets for $S$. heathii 
663

664

665

666

667

668

669

670

671

672

673

674

675

676

677

678

679

680

681

682

683

684

685

686

687

688

689

690

691

692

693

694

695

696

may be consistent with female philopatry and male-biased dispersal whereas those for $S$.

kuhlii do not exhibit sex-biased dispersal (Arnold \& Wilkinson, 2015; Rivers et al., 2005; Tu et al., 2017). As both species may have maintained gene flows among their populations, the geographic variation observed in external and craniodental traits might reflect their phenotypic plasticity to adapt to selective forces imposed by environmental variability, as well as interspecific competition for common resources in areas of sympatry (Chevin, Lande, \& Mace, 2010; Ghalambor, McKay, Carroll, \& Reznick, 2007; Lande, 2014; Spaeth, 2009; Tienderen, 1997; Zamudio, Bell, \& Mason, 2016).

The low morphological variation of $S$. kuhlii specimens throughout the Indomalayan Region suggests that the species has maintained a generalist phenotype suited to a variety of environments. By contrast, the morphological variability of $S$. heathii indicates that its geographic populations, even those at small scales, may have evolved plastic phenotypes that suit the particular habitats they inhabit (Chevin et al., 2010; Lande, 2014; Spaeth, 2009; Tienderen, 1997; Zamudio et al., 2016). As such, the generalist populations of S.kuhlii may have experienced fewer adverse effects from climate and associated habitat changes than $S$. heathii. They may also have had more advantages than $S$. heathii when colonizing and adapting to new habitats (Bonte et al., 2012; Ghalambor et al., 2007; Hollander, Verzijden, Svensson, \& Brönmark, 2014; Kelly, Panhuis, \& Stoehr, 2012; Lande, 2014; Moussy et al., 2013). These inferences suggest that $S$. heathii bats may be more philopatric to their native areas compared to S. kuhlii. If so, this would explain how S. kuhlii can occupy a wider geographic range in the Indomalayan Region relative to $S$. heathii (Figure 1), even though $S$. heathii would be expected to have greater dispersal ability based on its wing morphology.

It should be noted that bats of $S$. kuhlii and $S$. heathii found either in sympatry or allopatry do not overlap in most morphological traits (i.e. FA; Figures 3-6). As discussed above, it is very likely that $S$. kuhlii and S. heathii have co-existed for a long time. Both species are also known to share similar eco-ethological preferences and feeding guilds (Bates \& Harrison, 1997; Francis, 2008; Norberg \& Rayner, 1987). Because prey density usually decreases from cluttered to open habitats, strong interspecific competition likely occurred in areas of sympatry during their evolutionary history (Grether et al., 2013; Müller et al., 2012; Roeleke, Johannsen, \& Voigt, 2018). To reduce niche overlap, co-existing related species typically evolve mechanisms for resource partitioning (Chevin et al., 2010; Lande, 2014; Tienderen, 1997) that result in detectable differences in morphology or echolocation call 
697

698

699

700

701

702

703

704

705

706

707

708

709

710

711

712

713

714

715

716

717

718

719

720

721

722

723

724

725

726

727

728

729

730

parameters (Kingston et al., 2001; Zhang et al., 2007). This would be consistent with the morphological differences between the two species.

\section{Acknowledgements}

We would like to thank numerous agencies and individuals for their research permits and assistance during our study: In Vietnam, the Vietnam Administration of Forestry (MONRE), Nguyen Van Sinh, Le Xuan Canh and Nguyen Quang Truong of the IEBR (Hanoi); in Cambodia, the Centre for Biodiversity Conservation at the Royal University of Phnom Penh and Fauna \& Flora International; in Myanmar, the Ministry of Livestock, Fisheries and Rural Development; in Philippines, Juan Carlos T. Gonzalez and Edison A. Cosico of UPLB MNH. We are also grateful to Victor van Cakenberghe (UA, Belgium), Lincoln H. Schmitt (UWA, Australia), and Ibnu Maryanto (LIPI, Indonesia) for their kind help. We also thank the three anonymous reviewers for their helpful comments on the manuscript. This research was supported by the "ATM Barcode" funded by the MNHN, the network "Bibliothèque du Vivant" funded by the CNRS, the MNHN, the INRA, the CEA (Genoscope) to A.H and V.T.T; the Hungarian Scientific Research Fund - OTKA K112440, the National Research, Development and Innovation Fund of Hungary - NKFIH KH130360, and the SYNTHESYS Project, financed by the European Community Research Infrastructure Action under the FP7 "Capacities" Program to TG and GC; the NTP-NFTÖ-17 project funded by the Hungarian Ministry of Human Capacities to TG; a grant-in-aid on Research Program on Emerging and Re-emerging Infectious Diseases, Japan Agency for Medical Research and Development (AMED) (JP15fk0108005, JP16fk0108117, JP17fk0108217, JP18fk0108017, JP19fk0108097, and JP20fk0108097), a grant-in-aid from the Japan Society for the Promotion of Science 24405045 to S.A, K.K., and D.F.; the KAKENHI (18H04816, 18H02492, 18K19359, 18KK0207) and JRPs-LEAD with DFG to D.K.; the project TN18/T07 funded by the Vietnam Academy of Science and Technology (VAST) to T.A.T and N.T.S.; and the Rufford Foundation (UK).

\section{Data Availability Statement}

The authors confirm that the data supporting the findings of this study are available within the article and/or its supplementary materials. 


\section{References}

733

734

735

736

737

738

739

740

741

742

743

744

745

746

747

748

749

750

751

752

753

754

755

756

757

758

759

760

761

762

763

Aldhebiani, A. Y. (2018). Species concept and speciation. Saudi Journal of Biological Sciences, 25(3), 437-440. https://doi.org/10.1016/j.sjbs.2017.04.013

Allen, J. A. (1906). Mammals from the Island of Hainan, China. Bulletin of the American Museum of Natural History, 22, 463-490.

Arai, S., Aoki, K., Sơn, N. T., Tú, V. T., Kikuchi, F., Kinoshita, G., ... Oishi, K. (2019). Đakrông virus, a novel mobatvirus (Hantaviridae) harbored by the Stoliczka's Asian trident bat (Aselliscus stoliczkanus) in Vietnam. Scientific Reports, 9(1), 10239. https://doi.org/10.1038/s41598-019-46697-5

Arai, S., Kang, H. J., Gu, S. H., Ohdachi, S. D., Cook, J. A., Yashina, L. N., ... Yanagihara, R. (2016). Genetic diversity of Artybash virus in the Laxmann's shrew (Sorex caecutiens). Vector Borne and Zoonotic Diseases (Larchmont, N.Y.), 16(7), 468-475. https://doi.org/10.1089/vbz.2015.1903

Arnold, B. D., \& Wilkinson, G. S. (2015). Female natal philopatry and gene flow between divergent clades of Pallid bats (Antrozous pallidus). Journal of Mammalogy, 96(3), 531-540. https://doi.org/10.1093/jmammal/gyv058

Avise, J. C. (2000). Phylogeography: The history and formation of species. Cambridge: Harvard University Press.

Baker, R. J., \& Bradley, R. D. (2006). Speciation in mammals and the genetic species concept. Journal of Mammalogy, 87(4), 643-662. https://doi.org/10.1644/06-MAMMF-038R2.1

Bates, P. J. J., \& Harrison, D. L. (1997). Bats of the Indian Subcontinent. Sevenoaks, Kent, UK: Harrison Zoological Museum.

Bickford, D., Lohman, D. J., Sodhi, N. S., Ng, P. K. L., Meier, R., Winker, K., ... Das, I. (2007). Cryptic species as a window on diversity and conservation. Trends in Ecology \& Evolution, 22(3), 148-155. https://doi.org/10.1016/j.tree.2006.11.004

Bonte, D., Van Dyck, H., Bullock, J. M., Coulon, A., Delgado, M., Gibbs, M., Lehouck, V., Matthysen, E., Mustin, K., Saastamoinen, M., Schtickzelle, N., Stevens, V. M., Vandewoestijne, S., Baguette, M., Barton, K., Benton, T. G., Chaput-Bardy, A., Clobert, J., Dytham, C., ... Travis, J. M. J. (2012). Costs of dispersal. Biological Reviews, 87(2), 290-312. https://doi.org/10.1111/j.1469-185X.2011.00201.x

Bouckaert, R. R., Vaughan, T. G., Barido-Sottani, J., Duchêne, S., Fourment, M., Gavryushkina, A., ... Drummond, A. J. (2019). BEAST 2.5: An advanced software 
platform for Bayesian evolutionary analysis. PLoS Computational Biology, 15(4), e1006650. https://doi.org/10.1371/journal.pcbi.1006650

Chevin, L.-M., Lande, R., \& Mace, G. M. (2010). Adaptation, plasticity, and extinction in a changing environment: Towards a predictive theory. PLoS Biology, 8(4), e1000357. https://doi.org/10.1371/journal.pbio.1000357

Corbet, G. B., \& Hill, J. E. (1992). The mammals of the Indomalayan Region: A systematic review. Oxford: Natural History Museum and Oxford University Press.

de Queiroz, K. (2005). Ernst Mayr and the modern concept of species. Proceedings of the National Academy of Sciences, 102(suppl 1), 6600-6607. https://doi.org/10.1073/pnas.0502030102

de Queiroz, K. (2007). Species concepts and species delimitation. Systematic Biology, 56(6), 879-886. https://doi.org/10.1080/10635150701701083

Demos, T. C., Webala, P. W., Bartonjo, M., \& Patterson, B. D. (2018). Hidden diversity of African yellow house bats (Vespertilionidae, Scotophilus): Insights from multilocus phylogenetics and lineage delimitation. Frontiers in Ecology and Evolution, 6. https://doi.org/10.3389/fevo.2018.00086

Dobson, G. E. (1875). On the genus Scotophilus, with description of a new genus and species allied thereto. Proceedings of the Zoological Society of London, 368-373.

Dool, S. E., Puechmaille, S. J., Foley, N. M., Allegrini, B., Bastian, A., Mutumi, G. L., ... Jacobs, D. S. (2016). Nuclear introns outperform mitochondrial DNA in inter-specific phylogenetic reconstruction: Lessons from horseshoe bats (Rhinolophidae: Chiroptera). Molecular Phylogenetics and Evolution, 97, 196-212. https://doi.org/10.1016/j.ympev.2016.01.003

Ersts, P.J. (2020). Geographic Distance Matrix Generator (Version 1.2.3). American Museum of Natural History, Center for Biodiversity and Conservation. Available from http://biodiversityinformatics.amnh.org/open_source/gdmg.

Excoffier, L., Smouse, P. E., \& Quattro, J. M. (1992). Analysis of molecular variance inferred from metric distances among DNA haplotypes: Application to human mitochondrial DNA restriction data. Genetics, 131(2), 479-491.

Francis, C. M. (2008). A field guide to the mammals of South-East Asia. London: New Holland Publishers.

Francis, C. M., Borisenko, A. V., Ivanova, N. V., Eger, J. L., Lim, B. K., Guillén-Servent, A., ... Hebert, P. D. N. (2010). The role of DNA barcodes in understanding and 

conservation of mammal diversity in Southeast Asia. PLoS ONE, 5(9), e12575. https://doi.org/10.1371/journal.pone.0012575

Ghalambor, C. K., McKay, J. K., Carroll, S. P., \& Reznick, D. N. (2007). Adaptive versus non-adaptive phenotypic plasticity and the potential for contemporary adaptation in new environments. Functional Ecology, 21(3), 394-407. https://doi.org/10.1111/j.1365-2435.2007.01283.x

Grether, G. F., Anderson, C. N., Drury, J. P., Kirschel, A. N. G., Losin, N., Okamoto, K., \& Peiman, K. S. (2013). The evolutionary consequences of interspecific aggression: Aggression between species. Annals of the New York Academy of Sciences, 1289(1), 48-68. https://doi.org/10.1111/nyas. 12082

Hammer, Ø., Harper, D. A. T., \& Ryan, P. D. (2001). PAST: Paleontological statistics software package for education and data analysis. Palaeontologia Electronica, 4(1), 1-9. http://palaeo-electronica.org/2001_1/past/issue1_01.htm.

Hassanin, A., An, J., Ropiquet, A., Nguyen, T. T., \& Couloux, A. (2013). Combining multiple autosomal introns for studying shallow phylogeny and taxonomy of Laurasiatherian mammals: Application to the tribe Bovini (Cetartiodactyla, Bovidae). Molecular Phylogenetics and Evolution, 66(3), 766-775. https://doi.org/10.1016/j.ympev.2012.11.003

Hassanin, A., Delsuc, F., Ropiquet, A., Hammer, C., Jansen van Vuuren, B., Matthee, C., ... Couloux, A. (2012). Pattern and timing of diversification of Cetartiodactyla (Mammalia, Laurasiatheria), as revealed by a comprehensive analysis of mitochondrial genomes. Comptes Rendus Biologies, 335(1), 32-50. https://doi.org/10.1016/j.crvi.2011.11.002

Hassanin, A., Nesi, N., Marin, J., Kadjo, B., Pourrut, X., Leroy, É., Gembu, G.-C., Musaba Akawa, P., Ngoagouni, C., Nakouné, E., Ruedi, M., Tshikung, D., Pongombo Shongo, C., \& Bonillo, C. (2016). Comparative phylogeography of African fruit bats (Chiroptera, Pteropodidae) provide new insights into the outbreak of Ebola virus disease in West Africa, 2014-2016. Comptes Rendus Biologies, 339(11), 517-528. https://doi.org/10.1016/j.crvi.2016.09.005

Hill, J. E., \& Thonglongya, K. (1972). Bats from Thailand and Cambodia. Bulletin of the British Museum (Natural History)., 22, 171-196.

Hisheh, S., How, R. A., Suyanto, A., \& Schmitt, L. H. (2004). Implications of contrasting patterns of genetic variability in two vespertilionid bats from the Indonesian 
archipelago. Biological Journal of the Linnean Society, 83(3), 421-431.

$$
\text { https://doi.org/10.1111/j.1095-8312.2004.00401.x }
$$

Hoang, D. T., Chernomor, O., von Haeseler, A., Minh, B. Q., \& Vinh, L. S. (2018). UFBoot2: Improving the Ultrafast Bootstrap Approximation. Molecular Biology and Evolution, 35(2), 518-522. https://doi.org/10.1093/molbev/msx281

Hollander, J., Verzijden, M., Svensson, E., \& Brönmark, C. (2014). Dispersal and phenotypic plasticity. In L.-A. Hansson \& S. Åkesson (Eds.), Animal Movement Across Scales (pp. 110-125). https://doi.org/10.1093/acprof:oso/9780199677184.003.0007

Hutson, A. M., Kingston, T., Francis, C., \& Suyanto, A. (2008). Scotophilus celebensis. Retrieved November 30, 2018, from The IUCN Red List of Threatened Species 2008: E.T20065A9141459 website: http://dx.doi.org/10.2305/IUCN.UK.2008.RLTS.T20065A9141459.en.

Irwin, D. M., Kocher, T. D., \& Wilson, A. C. (1991). Evolution of the cytochrome b gene of mammals. Journal of Molecular Evolution, 32(2), 128-144.

Jung, K., \& Threlfall, C. G. (2016). Urbanisation and its effects on bats-A global metaanalysis. In C. C. Voigt \& T. Kingston (Eds.), Bats in the Anthropocene: Conservation of Bats in a Changing World (pp. 13-33). https://doi.org/10.1007/978-3-319-252209_2

Kelly, S. A., Panhuis, T. M., \& Stoehr, A. M. (2012). Phenotypic plasticity: Molecular mechanisms and adaptive significance. Comprehensive Physiology, 2(2), 1417-1439. https://doi.org/10.1002/cphy.c110008

Khan, F. A. A., Solari, S., Swier, V. J., Larsen, P. A., Abdullah, M. T., \& Baker, R. J. (2010). Systematics of Malaysian woolly bats (Vespertilionidae: Kerivoula) inferred from mitochondrial, nuclear, karyotypic, and morphological data. Journal of Mammalogy, 91(5), 1058-1072. https://doi.org/10.1644/09-MAMM-A-361.1

Kingston, T. (2010). Research priorities for bat conservation in Southeast Asia: A consensus approach. Biodiversity and Conservation, 19(2), 471-484. https://doi.org/10.1007/s10531-008-9458-5

Kingston, T., Lara, M. C., Jones, G., Akbar, Z., Kunz, T. H., \& Schneider, C. J. (2001). Acoustic divergence in two cryptic Hipposideros species: A role for social selection? Proceedings of the Royal Society B: Biological Sciences, 268(1474), 1381-1386. https://doi.org/10.1098/rspb.2001.1630

Kitchener, D. J., Packer, W. C., \& Maryanto, I. (1997). Morphological variation among populations of Scophilus kuhlii (sensu lato) Leach, 1821 (Chiroptera: 
Vespertilionidae) from the Greater and Lesser Sunda Islands, Indonesia. Tropical Biodiversity, 4(1), 53-81.

Lande, R. (2014). Evolution of phenotypic plasticity and environmental tolerance of a labile quantitative character in a fluctuating environment. Journal of Evolutionary Biology, 27(5), 866-875. https://doi.org/10.1111/jeb.12360

Larsson, A. (2014). AliView: A fast and lightweight alignment viewer and editor for large datasets. Bioinformatics, 30(22), 3276-3278. https://doi.org/10.1093/bioinformatics/btu531

Leigh, J. W., \& Bryant, D. (2015). POPART: Full-feature software for haplotype network construction. Methods in Ecology and Evolution, 6(9), 1110-1116. https://doi.org/10.1111/2041-210X.12410

Librado, P., \& Rozas, J. (2009). DnaSP v5: A software for comprehensive analysis of DNA polymorphism data. Bioinformatics, 25(11), 1451-1452. https://doi.org/10.1093/bioinformatics/btp187

López, V., Fernández, A., García, S., Palade, V., \& Herrera, F. (2013). An insight into classification with imbalanced data: Empirical results and current trends on using data intrinsic characteristics. Information Sciences, 250, 113-141. https://doi.org/10.1016/j.ins.2013.07.007

Luo, B., Santana, S. E., Pang, Y., Wang, M., Xiao, Y., \& Feng, J. (2019). Wing morphology predicts geographic range size in vespertilionid bats. Scientific Reports, 9(1), 4526. https://doi.org/10.1038/s41598-019-41125-0

Mantel, N. (1967). The Detection of Disease Clustering and a Generalized Regression Approach. Cancer Research, 27(2 Part 1), 209-220.

Mao, X., Zhu, G., Zhang, S., \& Rossiter, S. J. (2010). Pleistocene climatic cycling drives intra-specific diversification in the intermediate horseshoe bat (Rhinolophus affinis) in Southern China. Molecular Ecology, 19(13), 2754-2769. https://doi.org/10.1111/j.1365-294X.2010.04704.x

Mayr, E. (1942). Systematics and the origin of species from the viewpoint of a zoologist. New York: Columbia University Press.

Meirmans, P. G., \& Tienderen, P. H. V. (2004). GENOTYPE and GENODIVE: Two programs for the analysis of genetic diversity of asexual organisms. Molecular Ecology Notes, 4(4), 792-794. https://doi.org/10.1111/j.1471-8286.2004.00770.x

Moratelli, R., Burgin, C., Cláudio, V., Novaes, R., López-Baucells, A., \& Haslauer, R. (2019). Family Vespertilionidae (Vesper Bats). In D. E. Wilson \& R. A. Mittermeier 

(Eds.), Handbook of the Mammals of the World (Vol. 9, pp. 716-982). Barcelona: Lynx Edicions.

Moussy, C., Hosken, D. J., Mathews, F., Smith, G. C., Aegerter, J. N., \& Bearhop, S. (2013). Migration and dispersal patterns of bats and their influence on genetic structure: Bat movements and genetic structure. Mammal Review, 43(3), 183-195. https://doi.org/10.1111/j.1365-2907.2012.00218.x

Müller, J., Mehr, M., Bässler, C., Fenton, M. B., Hothorn, T., Pretzsch, H., ... Brandl, R. (2012). Aggregative response in bats: Prey abundance versus habitat. Oecologia, 169(3), 673-684. https://doi.org/10.1007/s00442-011-2247-y

Nabhan, A. R., \& Sarkar, I. N. (2012). The impact of taxon sampling on phylogenetic inference: A review of two decades of controversy. Briefings in Bioinformatics, 13(1), 122-134. https://doi.org/10.1093/bib/bbr014

Nesi, N., Nakouné, E., Cruaud, C., \& Hassanin, A. (2011). DNA barcoding of African fruit bats (Mammalia, Pteropodidae). The mitochondrial genome does not provide a reliable discrimination between Epomophorus gambianus and Micropteropus pusillus. Comptes Rendus Biologies, 334(7), 544-554. https://doi.org/10.1016/j.crvi.2011.05.003

Nguyen, L.-T., Schmidt, H. A., von Haeseler, A., \& Minh, B. Q. (2015). IQ-TREE: A fast and effective stochastic algorithm for estimating maximum-likelihood phylogenies. Molecular Biology and Evolution, 32(1), 268-274. https://doi.org/10.1093/molbev/msu300

Norberg, U. M., \& Rayner, J. M. V. (1987). Ecological morphology and flight in bats (Mammalia; Chiroptera): Wing adaptations, flight performance, foraging strategy and echolocation. Philosophical Transactions of the Royal Society of London. Series B, Biological Sciences, 316(1179), 335-427. https://doi.org/10.2307/2396486

Osgood, W. H. (1932). Mammals of the Kelley-Roosevelts and Delacour Asiatic expedition. Field Museum of Natural History - Zoological Series, 18, 193-339.

Posada, D. (2008). jModelTest: Phylogenetic model averaging. Molecular Biology and Evolution, 25(7), 1253-1256. https://doi.org/10.1093/molbev/msn083

Rambaut, A. (2009). FigTree v.1.4.0 2006-2012; http://tree.bio.ed.ac.uk/software/figtree/. Retrieved from http://tree.bio.ed.ac.uk/software/figtree/

Rivers, N. M., Butlin, R. K., \& Altringham, J. D. (2005). Genetic population structure of Natterer's bats explained by mating at swarming sites and philopatry. Molecular Ecology, 14(14), 4299-4312. https://doi.org/10.1111/j.1365-294X.2005.02748.x 
Roehrs, Z. P., Lack, J. B., \& Van Den Bussche, R. A. (2010). Tribal phylogenetic relationships within Vespertilioninae (Chiroptera: Vespertilionidae) based on mitochondrial and nuclear sequence data. Journal of Mammalogy, 91(5), 1073-1092. https://doi.org/10.1644/09-MAMM-A-325.1

Roeleke, M., Johannsen, L., \& Voigt, C. C. (2018). How bats escape the competitive exclusion principle-Seasonal shift from intraspecific to interspecific competition drives space use in a bat ensemble. Frontiers in Ecology and Evolution, 6, 101. https://doi.org/10.3389/fevo.2018.00101

Ronquist, F., Teslenko, M., van der Mark, P., Ayres, D. L., Darling, A., Hohna, S., ... Huelsenbeck, J. P. (2012). MrBayes 3.2: Efficient Bayesian phylogenetic inference and model choice across a large model space. Systematic Biology, 61(3), 539-542. https://doi.org/10.1093/sysbio/sys029

Sanborn, C. C. (1952). The mammals of the Rush Watkins Zoological Expedition to Siam. Natural History Bulletin of the Siam Society, 15(1), 1-20.

Shamel, H. H. (1942). A collection of bats from Thailand (Siam). Journal of Mammalogy, 23(3), 317-328. https://doi.org/10.2307/1375002

Siddiqi, M. S. U. (1960). Notes on the status of bats of the genus Scotophilus from Southern Asia with key to the recognized forms. Annals and Magazine of Natural History, 3(32), 449-454. https://doi.org/10.1080/00222936008651043

Simmons, N. B. (2005). Order Chiroptera. In D. E. Wilson \& D. M. Reeder (Eds.), Mammal species of the World: A Taxonomic and Geographic Reference (Third Edition, pp. 312-529). London: Johns Hopkins University Press.

Sinaga, U., \& Maryanto, I. (2008). Scotophilus collinus. Retrieved November 30, 2018, from The IUCN Red List of Threatened Species 2008: E.T136612A4318302 website: http://dx.doi.org/10.2305/IUCN.UK.2008.RLTS.T136612A4318302.en

Slatkin, M. (1987). Gene flow and the geographic structure of natural populations. Science, 236(4803), 787-792. https://doi.org/10.1126/science.3576198

Sodhi, N. S., \& Brook, B. W. (2006). Southeast Asian Biodiversity in Crisis. Cambridge University Press.

Sodhi, N. S., Posa, M. R. C., Lee, T. M., Bickford, D., Koh, L. P., \& Brook, B. W. (2010). The state and conservation of Southeast Asian biodiversity. Biodiversity and Conservation, 19(2), 317-328. https://doi.org/10.1007/s10531-009-9607-5

Sody, H. J. V. (1928). Twee nieuwe subspecies van Pachyotis temmincki Horsf. Natuurkundig Tijdschrift Voor Nederlandsch Indië, 88, 86-91. 
Sody, H. J. V. (1936). Seventeen new generic specific, and subspecific names for Dutch East Indian mammals. Natuurkundig Tijdschrift Voor Nederlandsch-Indie, 96, 42-55.

Spaeth, P. A. (2009). Morphological convergence and coexistence in three sympatric North American species of Microtus (Rodentia: Arvicolinae). Journal of Biogeography, 36(2), 350-361. https://doi.org/10.1111/j.1365-2699.2008.02015.x.

Srinivasulu, B. \& Srinivasulu, C. (2019a). Scotophilus heathii. Retrieved August 15, 2020, from The IUCN Red List of Threatened Species 2019: E.T20067A22031528 website: https://dx.doi.org/10.2305/IUCN.UK.2019-3.RLTS.T20067A22031528.en.

Srinivasulu, B. \& Srinivasulu, C. (2019b). Scotophilus kuhlii. Retrieved August 15, 2020, from The IUCN Red List of Threatened Species 2019: e.T20068A22031278 website: https://dx.doi.org/10.2305/IUCN.UK.2019-3.RLTS.T20068A22031278.en

Swofford, D. L. (2003). PAUP*. Phylogenetic Analysis Using Parsimony (*and Other Methods). Version 4. Sinauer Associates, Sunderland, Massachusetts.

Tate, G. H. H. (1942). Review of the vespertilionine bats, with special attention to genera and species of the Archbold collections. Bulletin of the American Museum of Natural History, 80(7), 221-297.

Thomas, O. (1897). On some Bats obtained in the Surat and Thana Districts by Mr R. C. Wroughton. Journal of the Bombay Natural History Society, 11, 274-276.

Tienderen, P. H. van. (1997). Generalists, specialists, and the evolution of phenotypic plasticity in sympatric populations of distinct Species. Evolution, 51(5), 1372-1380. https://doi.org/10.1111/j.1558-5646.1997.tb01460.x

Trifinopoulos, J., Nguyen, L.-T., von Haeseler, A., \& Minh, B. Q. (2016). W-IQ-TREE: A fast online phylogenetic tool for maximum likelihood analysis. Nucleic Acids Research, 44(W1), W232-235. https://doi.org/10.1093/nar/gkw256

Trujillo, R. G., Patton, J. C., Schlitter, D. A., \& Bickham, J. W. (2009). Molecular phylogenetics of the bat genus Scotophilus (Chiroptera: Vespertilionidae): Perspectives from paternally and maternally inherited genomes. Journal of Mammalogy, 90(3), 548-560. https://doi.org/10.1644/08-MAMM-A-239R2.1

Tu, V. T., Csorba, G., Ruedi, M., Furey, N. M., Son, N. T., Thong, V. D., ... Hassanin, A. (2017). Comparative phylogeography of bamboo bats of the genus Tylonycteris (Chiroptera, Vespertilionidae) in Southeast Asia. European Journal of Taxonomy, 274, 1-38. https://doi.org/10.5852/ejt.2017.274

Tu, V. T., Hassanin, A., Furey, N. M., Son, N. T., \& Csorba, G. (2018). Four species in one: Multigene analyses reveal phylogenetic patterns within Hardwicke's woolly bat, 
1001

1002

1003

1004

1005

1006

1007

1008

1009

1010

1011

1012

1013

1014

1015

1016

1017

1018

1019

1020

1021

1022

1023

1024

1025

1026

1027

1028

1029

1030

1031

1032

1033

Kerivoula hardwickii-complex (Chiroptera, Vespertilionidae) in Asia. Hystrix, the Italian Journal of Mammalogy, 29(1), 111-121. https://doi.org/10.4404/hystrix00017-2017

Vallo, P., Nkrumah, E. E., Tehoda, P., Benda, P., Badu, E. K., \& Decher, J. (2016). Nutlet is a little nut: Disclosure of the phylogenetic position of Robbins' house bat Scotophilus nucella (Vespertilionidae). Folia Zoologica, 65(4), 302-309. https://doi.org/10.25225/fozo.v65.i4.a2.2016

Vallo, P., Reeder, D. M., Vodzak, M. E., \& Benda, P. (2019). Resurrection of an East African house bat species Scotophilus altilis Allen, 1914 (Chiroptera: Vespertilionidae). Zootaxa, 4577(1), 148. https://doi.org/10.11646/zootaxa.4577.1.9

Vallo, P., \& Van Cakenberghe, V. (2017). Advances in taxonomy of African House Bats (Scotophilus, Vespertilionidae). African Bat Conservation News, 46, 4-9.

Wilson, D. E., \& Reeder, D. M. (2005). Mammal Species of the World: A Taxonomic and Geographic Reference (3rd ed.). Baltimore: Johns Hopkins University Press.

Yu, W., Chen, Z., Li, Y., \& Wu, Y. (2012). Phylogeographic relationships of Scotophilus kuhlii between Hainan island and mainland China. Mammal Study, 37(2), 139-146. https://doi.org/10.3106/041.037.0204

Zamudio, K. R., Bell, R. C., \& Mason, N. A. (2016). Phenotypes in phylogeography: Species’ traits, environmental variation, and vertebrate diversification. Proceedings of the National Academy of Sciences, 113(29), 8041-8048. https://doi.org/10.1073/pnas.1602237113

Zar, J. H. (1999). Biostatistical Analysis (4th ed.). New Jersey: Prentice Hall.

Zhang, L., Liang, B., Parsons, S., Wei, L., \& Zhang, S. (2007). Morphology, echolocation and foraging behaviour in two sympatric sibling species of bat (Tylonycteris pachypus and Tylonycteris robustula) (Chiroptera: Vespertilionidae). Journal of Zoology, 271(3), 344-351. https://doi.org/10.1111/j.1469-7998.2006.00210.x

Zhu, G., Chmura, A., \& Zhang, L. (2012). Morphology, echolocation calls and diet of Scotophilus kuhlii (Chiroptera: Vespertilionidae) on Hainan island, South China. Acta Chiropterologica, 14(1), 175-181. https://doi.org/10.3161/150811012X654394

Zwickl, D. J., \& Hillis, D. M. (2002). Increased taxon sampling greatly reduces phylogenetic error. Systematic Biology, 51(4), 588-598. https://doi.org/10.1080/10635150290102339 
1034

1035

1036

1037 


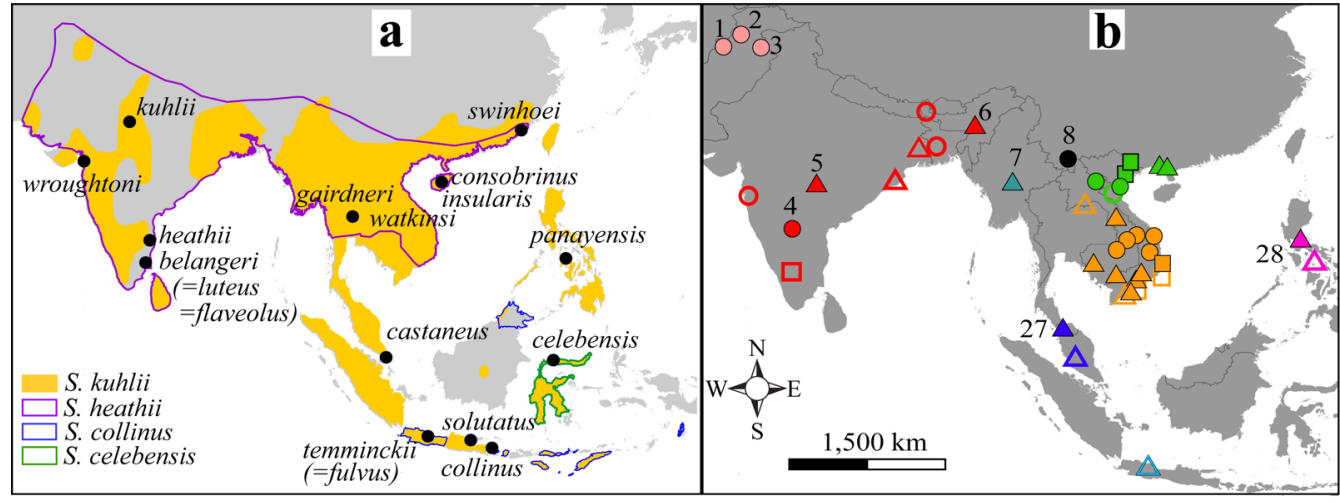

Figure 1. Phylogeographic patterns of Asian Scotophilus spp. based on the mitochondrial (COI and $C y t b)$ markers.

1042 a: IUCN distribution range of four recently recognized Asian Scotophilus spp. Black dots

1043 refer to type localities of formerly described species or subspecies of Scotophilus in Asia (See

1044 Table S1). Note that the type locality of S. kuhlii in India is uncertain. b-c: Locations for

1045 which specimens of S. kuhlii, S. heathii or both species were collected are shown as triangles,

1046 circles and squares, respectively. Localities for specimens included in genetic analyses are

1047 filled and numbered whereas those of individuals in morphological analyses only are empty.

1048 MtDNA haplotypes of examined specimens in the TCS networks and their corresponding

1049 locations are indicated by the same colour and by numbers before and after colons,

1050 respectively (See Appendix 1 and Table S2 for more details). 
a) $\mathrm{COI}$
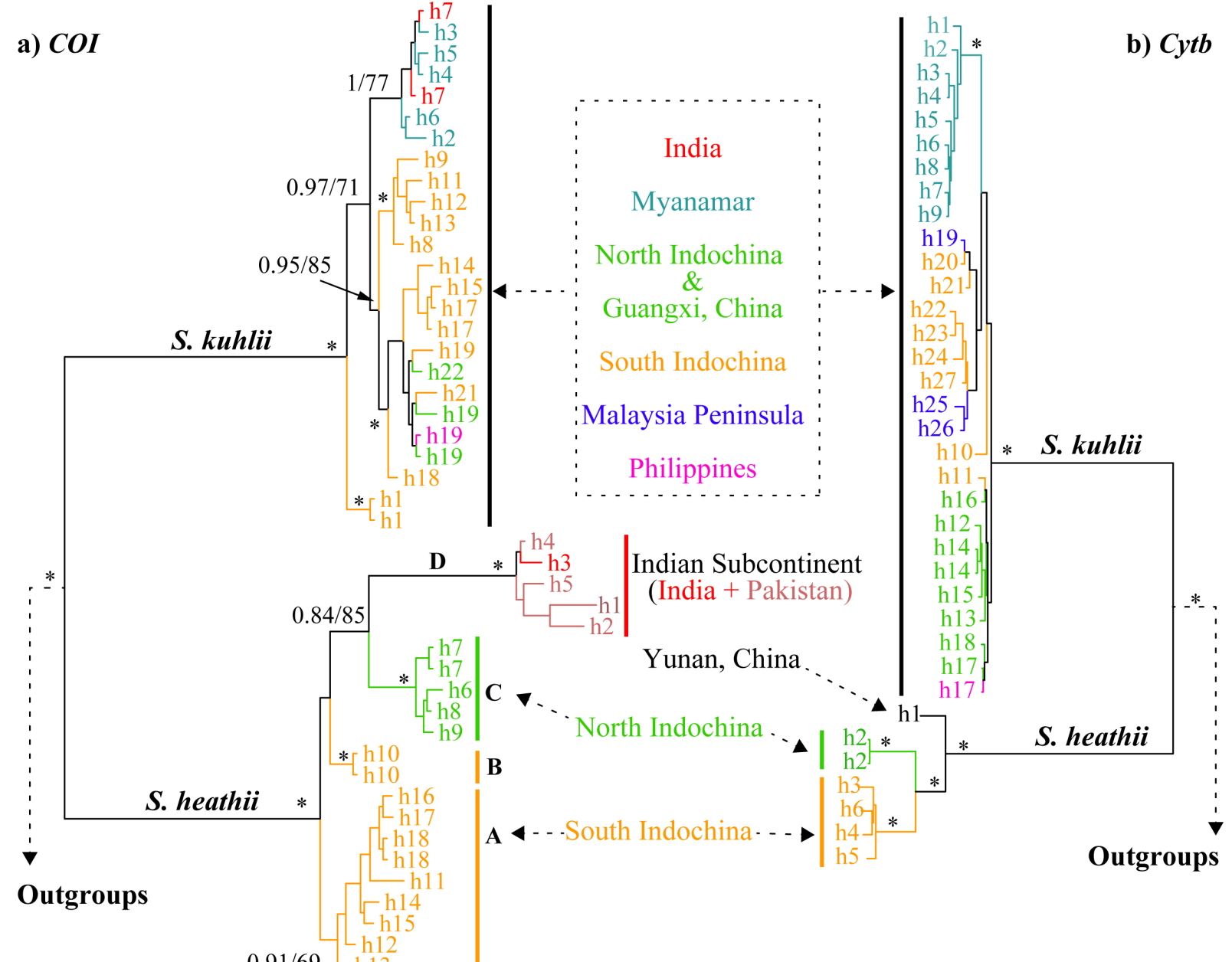

$0.91 / 69$

S. $\boldsymbol{k}$ uhlii $*$ T5000 TUFM: 44d(K), 395d(GGA) $401 \mathrm{~d}(\mathrm{C}), 407 \mathrm{i}(\mathrm{GATC}), 523 \mathrm{~d}(\mathrm{~A}), 565 \mathrm{i}(\mathrm{TC})$ ZFYVE27: 180d(25nt); 326d(D); 391d(G)

1053 Figure 2. Phylogenetic trees of Asian Scotophilus spp. and outgroups.

1054 Values on nodes indicate Bayesian posterior probabilities (PP)/Maximum-Likelihood 1055 bootstrap percentage (BP) ( $\mathrm{PP}<0.7$ and $\mathrm{BP}<70 \%$ are not shown). The asterisks $\left(^{*}\right)$ indicate 1056 that the node was supported by $\mathrm{PP} \geq 0.9 / \mathrm{BP} \geq 90$. The colours of mtDNA haplotypes match 1057 those in Figure 1. The position and nature of all diagnostic indels (i: insertion; d: deletion) 1058 shared by at least two taxa in the alignments of nuclear genes are indicated in boxes. 


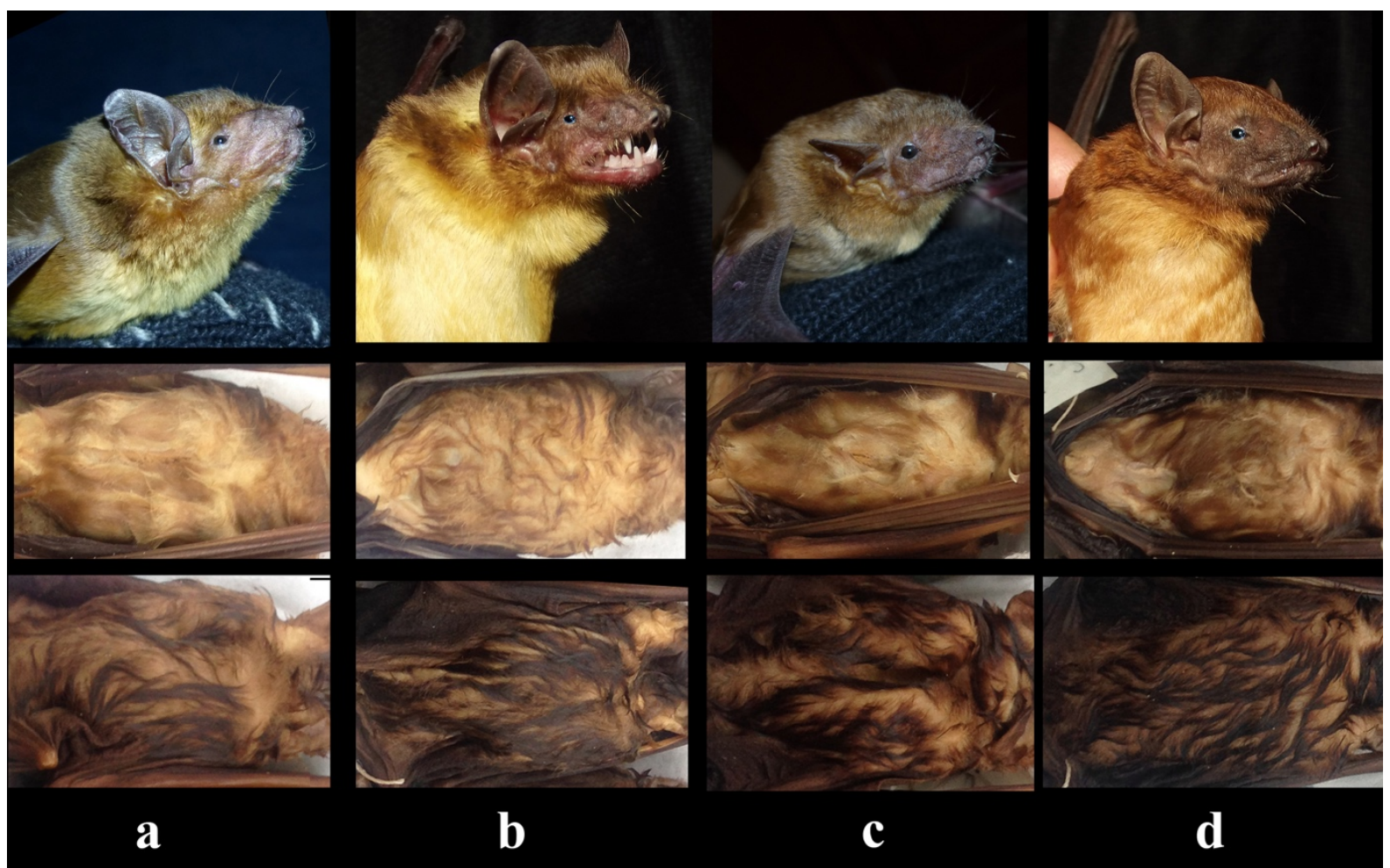

1059

Figure 3. Live and wet specimens (not to scale) of Scotophilus heathii and S. kuhlii

1061 collected in sympatry in two different regions of Vietnam.

1062 Northern Vietnam (Location 10): a - S. heathii / c - S. kuhlii. South-Central Vietnam

1063 (Location 21): b - S. heathii / d - S. kuhlii 


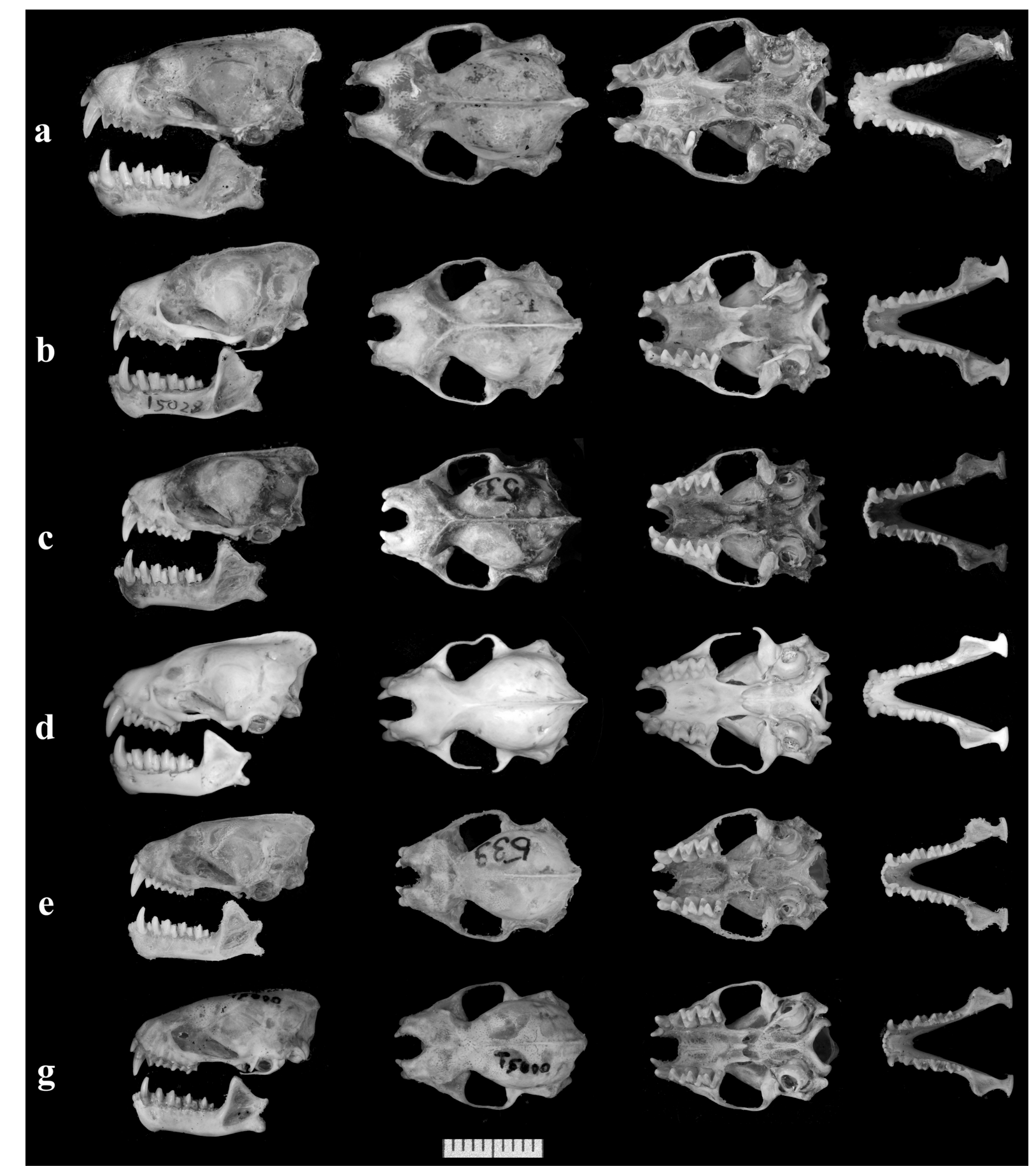

1064

1065 Figure 4. Skull profiles of selected Asian Scotophilus spp.

1066 S. heathii s.s.: a - Highland Central Vietnam (loc. 19; IEBR-M-4550), b - Northern Vietnam 1067 (loc. 10; IEBR. T5028) and c - South Central Vietnam (loc. 21; IEBR. VN17-533); S. ? 1068 solutatus s.s.: d - Java, Indonesia (HNHM 2869.22); and S. kuhlii s.s.: e - South Central 1069 Vietnam (loc. 21; IEBR. VN17-539) and g - Northern Vietnam (loc. 10; IEBR. T5000). Scale $1070=10 \mathrm{~mm}$.

1071 

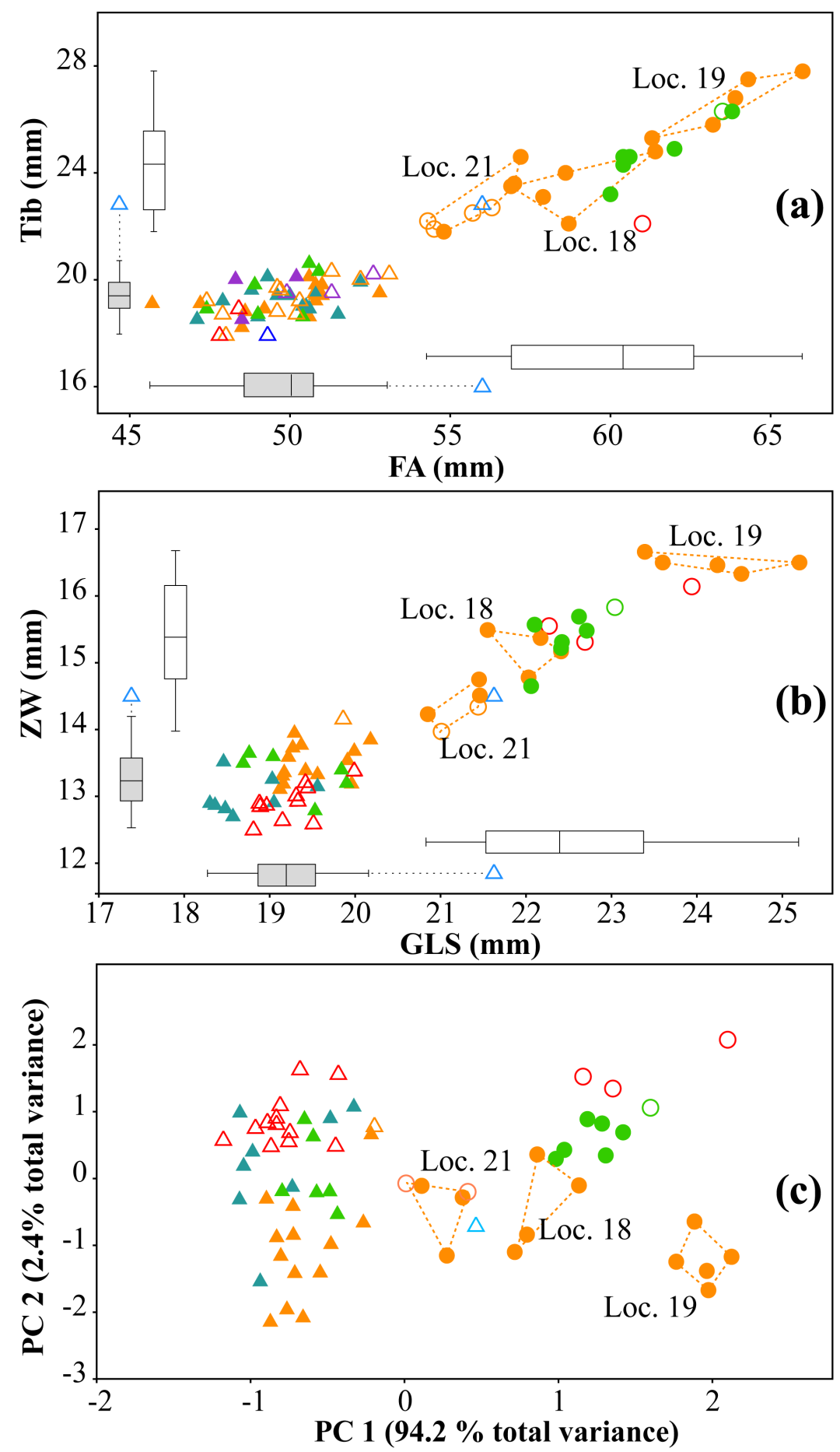

PC 1 (94.2\% total variance)

1074 Figure 5. Scatter plots from morphological analyses of Asian Scotophilus spp.

1075 a and b: Variation in external (FA vs. Tib) and skull traits (GSL vs. ZB) among specimens of

1076 Scotophilus spp., respectively. Boxplots (with an interquartile range) to find outliers in the

1077 datasets were embedded; c: Plot of PC 1 against PC 2 from PCA on log-transformed

1078 craniodental measurements. The legends of symbols follow Figure 1. Bats of S. heathii found

1079 in three spatially isolated locations $(18,19$, and 21) in Southern Indochina (Figure 1) appear

1080 as three relatively separated subpopulations. 


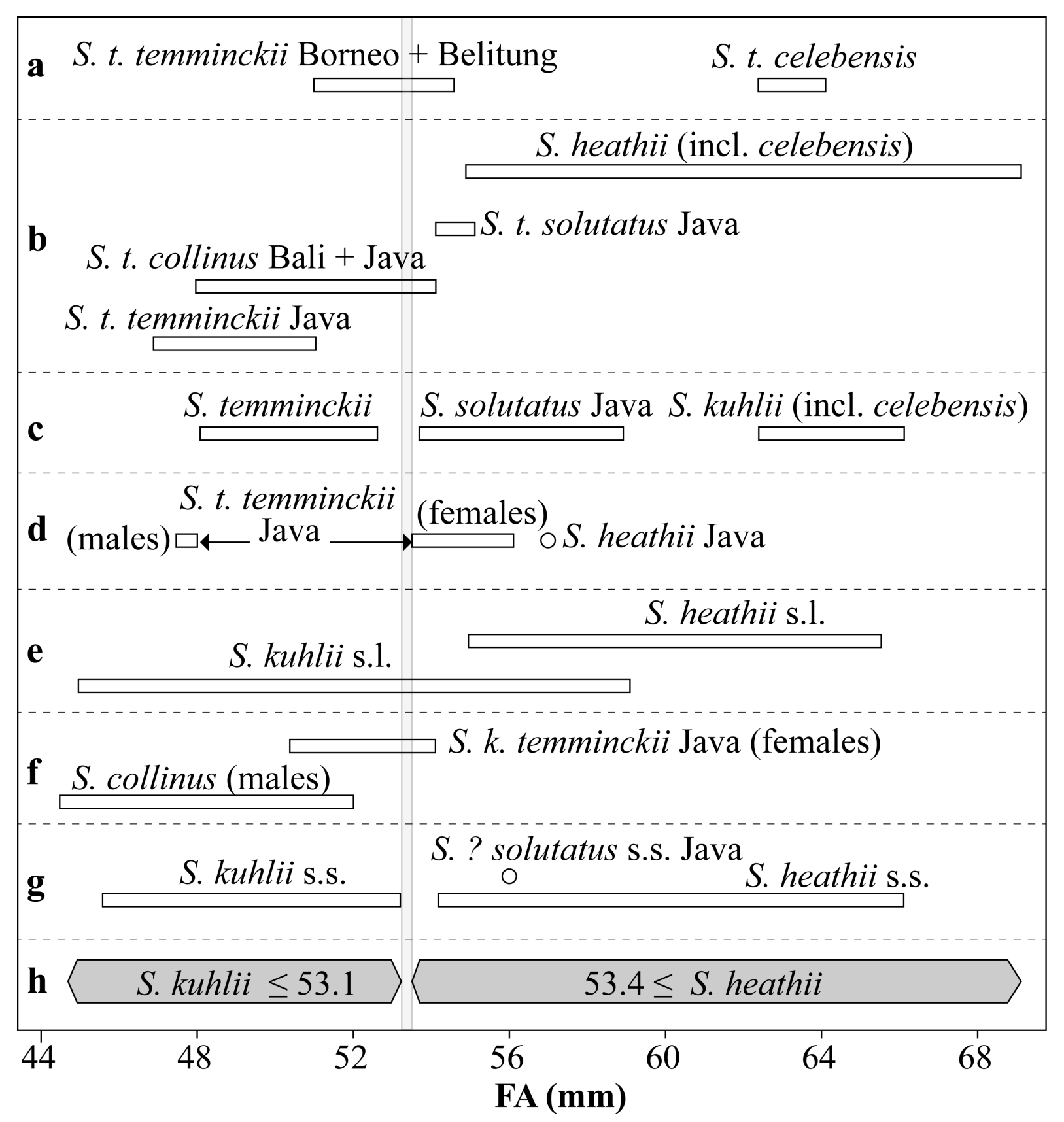

Figure 6. Pairwise comparison of FA ranges (min-max) for Asian Scotophilus spp.

1084 recognized in present and previous studies.

1085 a - Sody, 1928; b - Tate, 1942; c - Shamel, 1942; d - Siddiqi, 1960; e - Corbet \& Hill, 1992;

$1086 \mathrm{f}$ - Kitchener et al. (1997); g - this study; and h-desired ranges for S. kuhiii and S. heathii. 
Table 1: Synopsis of taxonomic studies on Asian Scotophilus between 1940-2000

\begin{tabular}{|c|c|c|}
\hline Author & Reference materials & Taxonomic treatment \\
\hline \multirow[t]{2}{*}[1]{} & $\begin{array}{l}\text { India, Hainan, Taiwan } \\
\text { (Formosa), Malacca, Java, } \\
\text { Bali, Luzon }\end{array}$ & $\begin{array}{l}\text { S. kuhlii (forearm length (FA, in mm): } 41 \text {, immature holotype) } \\
\text { S. temminckii (=fulvus) (FA } \leq 51) \text { includes consobrinus, castaneus, } \\
\text { wroughtoni, panayensis, collinus, and gairdneri as similar sized races/ } \\
\text { synonyms and a larger sized Javanese one, solutatus (FA: 55-55). }\end{array}$ \\
\hline & $\begin{array}{l}\text { India: Kashmir, Myanmar } \\
\text { (Burma), Hainan, Sri } \\
\text { Lanka (Ceylon) }\end{array}$ & $\begin{array}{l}\text { S. heathii }(\mathrm{FA} \geq 54) \text { with belangeri }(=\text { luteus=flaveolus }) \text {, insularis, and } \\
\text { celebensis as races/synonyms }\end{array}$ \\
\hline \multirow[t]{3}{*}[2]{} & $\begin{array}{l}\text { Java, Singapore, Thailand, } \\
\text { French Indochina }\end{array}$ & $\begin{array}{l}\text { Pachyotis temminckii (FA: 48.2-52.5) includes temminckii=castaneus, } \\
\text { consobrinus, wroughtoni, panayensis, collinus, and gairdneri as } \\
\text { synonyms/ races }\end{array}$ \\
\hline & $\begin{array}{l}\text { West Java, Depok, } \\
\text { Pelabuhan }\end{array}$ & P. solutatus (FA: 53.8-58.9) \\
\hline & $\begin{array}{l}\text { Thailand (Siam), French } \\
\text { Indochina, Ceylon }\end{array}$ & $\begin{array}{l}\text { Pachyotis kuhlii (FA: 60-66) includes insularis, and celebensis as } \\
\text { races }\end{array}$ \\
\hline [3] & Thailand & $\begin{array}{l}\text { S. s. solutatus: Java, and S. solutatus watkinsi ssp. nov. (FA: } 55.5- \\
60.5) \text {. Type locality: Pak Nam Pho, Nakhon Sawan, Thailand. }\end{array}$ \\
\hline \multirow[t]{4}{*}[4]{} & \multirow{4}{*}{$\begin{array}{l}\text { Collection in the British } \\
\text { Museum (N.H.) }\end{array}$} & S. t. temminckii (FA of males / females: 47.6-47.9 / 53.4-56.0): Java \\
\hline & & $\begin{array}{l}\text { S. t. castaneus (FA: 47.6-52.4): Malay Peninsula; Upper Burma; South } \\
\text { China; India: Calcutta }\end{array}$ \\
\hline & & S. t. wroughtoni (FA: 45.2-52.4): Ceylon and India \\
\hline & & $\begin{array}{l}\text { S. h. heathii (56.2-63.8): Ceylon, India, Pakistan, Burma, Siam and } \\
\text { Java }\end{array}$ \\
\hline \multirow[t]{2}{*}[5]{} & \multirow[t]{2}{*}{$\begin{array}{l}\text { Collection in the British } \\
\text { Museum (N.H.) }\end{array}$} & $\begin{array}{l}\text { S. kuhlii replaced } S \text {. temminckii as generic name of smaller sized } \\
\text { species. Its subspecies/ races include temminckii, castaneus, collinus, } \\
\text { consobrinus, gairdneri, panayensis, solutalus and wroughtoni. }\end{array}$ \\
\hline & & S. h. heathii (Indian and Burma) and S. h. (?) watkinsi (FA: 61.2-61.4) \\
\hline \multirow[t]{2}{*}[6]{} & \multirow[t]{2}{*}{$\begin{array}{l}\text { Synthesis from previous } \\
\text { studies }\end{array}$} & $\begin{array}{l}\text { S. kuhlii (FA: 45-59) comprises castaneus, consobrinus, fulvus, } \\
\text { gairdneri, panayensis, solutanus, swinhoei, temminckii, and } \\
\text { wroughtoni as synonyms/races found throughout the Indomalayan } \\
\text { Region. The largest specimens (or } S . \text { k. solutanus) occur apprarently } \\
\text { in Java. }\end{array}$ \\
\hline & & $\begin{array}{l}\text { S. heathii (FA: 55-65.5) includes belangeri, flaveolus, insularis, } \\
\text { luteus, watkinsi (from Afghanistan to Vietnam) and probably } \\
\text { celebensis (Sulawesi) as subspecies/synonyms }\end{array}$ \\
\hline$[7]$ & $\begin{array}{l}\text { S. kuhlii s. } 1 .(\mathrm{FA}<54) \\
\text { collected from Greater } \\
\text { (Java), Lesser Sunda and } \\
\text { Borneo islands }\end{array}$ & $\begin{array}{l}\text { - S. } \text { k. temminckii (FA of males: } 52.2-53.7 \text { ): Java and } S . \text { k. solutatus } \\
\text { (FA of males: } 50.3-52.4 \text { ): East Java and Bali; } \\
\text { - S. collinus: Sundaic form (FA of males: } 45.2-51.4 \text { ): Sabah, Java and } \\
\text { Bali; Nusa Tenggara form (FA of males: 44.6-51.9): Lombok to Timor }\end{array}$ \\
\hline
\end{tabular}
described as new to science (detailed in Figure 1; Table S1). Authors: 1 - Tate, 1942; 2 Shamel, 1942; 3 - Sanborn, 1952; 4 - Siddiqui, 1960; 5 - Hill \& Thonglongya, 1972; 6 - 
1097

1098

1099

Table 2: Range (min-max) of uncorrected p-distances (\%) between Asian Scotophilus spp. and selected outgroups, based on $C O I(C y t b)$ (below the diagonal) and nuDNA (above the diagonal) datasets.

\begin{tabular}{|c|c|c|c|c|c|c|c|c|}
\hline \multirow{2}{*}{\multicolumn{2}{|c|}{ Taxon }} & \multirow{2}{*}{1} & \multirow{2}{*}{2} & \multirow{2}{*}{3} & \multicolumn{4}{|c|}{4} \\
\hline & & & & & $\mathbf{A}$ & B & $\mathbf{C}$ & D \\
\hline \multicolumn{2}{|l|}{ 1. M. cyclotis } & & 9.5 & $11.3-11.7$ & $11.3-11.3$ & NA & $11.6-11.6$ & NA \\
\hline \multicolumn{2}{|c|}{ 2. E. pachyomus } & $20.1(19.6)$ & & $6.8-7.0$ & $6.8-6.9$ & NA & $6.8-6.9$ & NA \\
\hline \multicolumn{2}{|l|}{ 3. S. kuhlii } & $\begin{array}{c}21.1-22.7 \\
(19.7-20.3)\end{array}$ & $\begin{array}{c}20.9-21.8 \\
(21.1-21.7)\end{array}$ & $\begin{array}{c}0.0 \\
2.3(2.2)\end{array}$ & $1.4-1.6$ & NA & $1.5-1.7$ & NA \\
\hline \multirow{5}{*}{ 4. S. heathii } & $\mathbf{A}$ & $\begin{array}{c}21.5-22.1 \\
(22.1-22.5)\end{array}$ & $\begin{array}{c}20.5-21.2 \\
(21.1-21.3)\end{array}$ & $\begin{array}{c}13.9-15.2 \\
(14.5-15.9)\end{array}$ & $\begin{array}{c}0.0 \\
1.6(1.0)\end{array}$ & NA & $0.0-0.1$ & NA \\
\hline & B & $\begin{array}{c}21.8-21.8 \\
\text { (NA) }\end{array}$ & $\begin{array}{c}21.3-21.3 \\
\text { (NA) }\end{array}$ & $\begin{array}{c}14.3-15.4 \\
\text { (NA) }\end{array}$ & $\begin{array}{c}1.1-2.3 \\
\text { (NA) }\end{array}$ & $\begin{array}{c}\text { NA } \\
0.0 \text { (NA) }\end{array}$ & NA & NA \\
\hline & $\mathbf{C}$ & $\begin{array}{c}21.8-22.1 \\
(21.8-21.8)\end{array}$ & $\begin{array}{l}21.0-21.2 \\
(20.6-20.6)\end{array}$ & $\begin{array}{l}14.3-15.7 \\
(15.2-16.0)\end{array}$ & $\begin{array}{c}2.6-4.0 \\
(3.7-3.9)\end{array}$ & $\begin{array}{c}\text { NA } \\
(3.8-4.2)\end{array}$ & $\begin{array}{c}0.0 \\
0.6(0-0)\end{array}$ & NA \\
\hline & D & $\begin{array}{c}21.9-23.4 \\
\text { (NA) }\end{array}$ & $\begin{array}{c}20.7-21.3 \\
\text { (NA) }\end{array}$ & $\begin{array}{c}16.0-18.3 \\
\text { (NA) }\end{array}$ & $\begin{array}{c}5.2-7.6 \\
\text { (NA) }\end{array}$ & $\begin{array}{c}5.5-6.9 \\
\text { (NA) }\end{array}$ & $\begin{array}{c}5.1-7.1 \\
\text { (NA) }\end{array}$ & $\begin{array}{c}\text { NA } \\
2.0 \text { (NA) }\end{array}$ \\
\hline & $\mathbf{E}$ & $\begin{array}{c}\text { NA } \\
(21.4)\end{array}$ & $\begin{array}{c}\text { NA } \\
(21.1)\end{array}$ & $\begin{array}{c}\text { NA } \\
(14.0-14.9)\end{array}$ & $\begin{array}{c}\text { NA } \\
(4.0-4.0)\end{array}$ & $\begin{array}{l}\text { NA } \\
\text { (NA) }\end{array}$ & $\begin{array}{c}\text { NA } \\
(3.8-4.2)\end{array}$ & $\begin{array}{l}\text { NA } \\
\text { (NA) }\end{array}$ \\
\hline
\end{tabular}

1100

1101 Taxon: A - D and E are corresponding lineages A - D and Yunnan, China of S. heathii in

1102 Figure 2. Values in diagonal in bold show the maximum intraspecific distances within each

1103 taxon calculated from the respective datasets; NA - not available. 
1106 Acronyms and definitions for measurements are given in the Materials and Methods section.

\begin{tabular}{|c|c|c|c|c|c|c|c|c|c|c|}
\hline \multirow[b]{2}{*}{ Character } & \multicolumn{7}{|c|}{ S. kuhlii s.l. } & \multicolumn{3}{|c|}{ S. heathii s.l. } \\
\hline & $\begin{array}{c}\text { North } \\
\text { Indochina }\end{array}$ & South Indochina & Myanmar & $\begin{array}{c}\text { Indian } \\
\text { Subcontinental }\end{array}$ & \begin{tabular}{|l|} 
Malaysia \\
Peninsula
\end{tabular} & Philippines & \begin{tabular}{|c|} 
Indonesia \\
(Java)*
\end{tabular} & $\begin{array}{c}\text { North } \\
\text { Indochina }\end{array}$ & South Indochina & $\begin{array}{c}\text { Indian } \\
\text { Subcontinental }\end{array}$ \\
\hline FA & $\begin{array}{c}49.5 \pm 1.3 ; 6 \\
47.4-50.9 \\
\end{array}$ & $\begin{array}{c}49.9 \pm 1.7 ; 26 \\
45.7-53.1 \\
\end{array}$ & $\begin{array}{c}49.8 \pm 1.4 ; 14 \\
47.1-52.2 \\
\end{array}$ & $\begin{array}{c}48.1 \pm 0.4 ; 2 \\
47.8-48.4 \\
\end{array}$ & $49.3 ; 1$ & $\begin{array}{c}50.1 \pm 1.6 ; 6 \\
48.3-52.6 \\
\end{array}$ & $56.0 ; 1$ & $\begin{array}{c}61.5 \pm 1.6 ; 7 \\
60.0-63.8 \\
\end{array}$ & $\begin{array}{c}58.9 \pm 3.7 ; 17 \\
54.3-66.0\end{array}$ & $61.0 ; 1$ \\
\hline Tib & $\begin{array}{c}19.6 \pm 0.9 ; 6 \\
18.7-20.7\end{array}$ & $\begin{array}{c}19.4 \pm 0.6 ; 26 \\
18.0-20.4\end{array}$ & $\begin{array}{c}19.3 \pm 0.5 ; 14 \\
18.6-20.2\end{array}$ & $\begin{array}{c}18.5 \pm 0.8 ; 2 \\
18.0-19.0\end{array}$ & $18.0 ; 1$ & $\begin{array}{c}19.7 \pm 0.6 ; 6 \\
18.6-20.3\end{array}$ & $22.9 ; 1$ & $\begin{array}{c}24.9 \pm 1.1 ; 7 \\
23.2-26.3\end{array}$ & $\begin{array}{c}24.1 \pm 2.0 ; 17 \\
21.8-27.8\end{array}$ & $22.1 ; 1$ \\
\hline GSL & $\begin{array}{c}19.29 \pm 0.54 ; 6 \\
18.69-19.90\end{array}$ & $\begin{array}{c}19.54 \pm 0.37 ; 14 \\
19.15-20.18\end{array}$ & $\begin{array}{c}18.73 \pm 0.44 ; 8 \\
18.30-19.56\end{array}$ & $\begin{array}{c}19.24 \pm 0.34 ; 12 \\
18.81-19.99\end{array}$ & - & - & $21.68 ; 1$ & $\begin{array}{c}22.48 \pm 0.35 ; 7 \\
22.06-23.04\end{array}$ & $\begin{array}{c}22.52 \pm 1.41 ; 14 \\
20.85-25.20\end{array}$ & $\begin{array}{c}22.97 \pm 0.87 ; 3 \\
22.27-23.94\end{array}$ \\
\hline SL & $\begin{array}{c}18.45 \pm 0.52 ; 6 \\
17.66-19.11\end{array}$ & $\begin{array}{c}18.70 \pm 0.27 ; 14 \\
18.19-19.11 \\
\end{array}$ & $\begin{array}{c}18.25 \pm 0.51 ; 8 \\
17.64-18.98\end{array}$ & $\begin{array}{c}18.17 \pm 0.33 ; 12 \\
17.68-18.80\end{array}$ & - & - & $20.43 ; 1$ & $\begin{array}{c}21.37 \pm 0.35 ; 7 \\
20.80-21.90\end{array}$ & $\begin{array}{c}21.43 \pm 1.34 ; 14 \\
19.78-23.50\end{array}$ & $\begin{array}{c}21.83 \pm 0.96 ; 3 \\
20.97-22.87\end{array}$ \\
\hline CBL & $\begin{array}{c}17.59 \pm 0.25 ; 6 \\
17.30-17.90\end{array}$ & $\begin{array}{c}17.49 \pm 0.30 ; 14 \\
16.95-17.90 \\
\end{array}$ & $\begin{array}{c}17.30 \pm 0.58 ; 8 \\
16.48-18.05 \\
\end{array}$ & $\begin{array}{c}17.10 \pm 0.33 ; 12 \\
16.40-17.61 \\
\end{array}$ & - & - & $18.76 ; 1$ & $\begin{array}{c}19.76 \pm 0.33 ; 7 \\
19.31-20.26 \\
\end{array}$ & $\begin{array}{c}19.74 \pm 1.26 ; 14 \\
17.97-21.39 \\
\end{array}$ & $\begin{array}{c}20.00 \pm 0.76 ; 3 \\
19.32-20.82 \\
\end{array}$ \\
\hline CCL & $\begin{array}{c}17.55 \pm 0.19 ; 6 \\
17.24-17.81\end{array}$ & $\begin{array}{c}17.71 \pm 0.30 ; 14 \\
17.27-18.21 \\
\end{array}$ & $\begin{array}{c}17.34 \pm 0.53 ; 8 \\
16.80-18.11 \\
\end{array}$ & $\begin{array}{c}17.44 \pm 0.28 ; 12 \\
16.93-17.83\end{array}$ & - & - & $19.26 ; 1$ & $\begin{array}{c}20.01 \pm 0.42 ; 7 \\
19.46-20.48\end{array}$ & $\begin{array}{c}19.94 \pm 1.30 ; 14 \\
18.14-21.61\end{array}$ & $\begin{array}{c}20.47 \pm 0.85 ; 3 \\
19.72-21.40 \\
\end{array}$ \\
\hline $\mathbf{Z B}$ & $\begin{array}{c}13.39 \pm 0.32 ; 6 \\
12.82-13.68\end{array}$ & $\begin{array}{c}13.61 \pm 0.30 ; 14 \\
13.22-14.19\end{array}$ & $\begin{array}{c}13.05 \pm 0.27 ; 8 \\
12.73-13.55\end{array}$ & $\begin{array}{c}12.96 \pm 0.26 ; 12 \\
12.53-13.41\end{array}$ & - & - & $14.54 ; 1$ & $\begin{array}{c}15.39 \pm 0.39 ; 7 \\
14.65-15.83\end{array}$ & $\begin{array}{c}15.36 \pm 0.97 ; 14 \\
13.97-16.66\end{array}$ & $\begin{array}{c}15.67 \pm 0.43 ; 3 \\
15.31-16.14\end{array}$ \\
\hline $\mathrm{C}^{1} \mathrm{C}^{1}$ & $\begin{array}{c}6.26 \pm 0.10 ; 6 \\
6.10-6.35 \\
\end{array}$ & $\begin{array}{c}6.14 \pm 0.24 ; 14 \\
5.75-6.58 \\
\end{array}$ & $\begin{array}{c}6.23 \pm 0.27 ; 8 \\
5.95-6.66\end{array}$ & $\begin{array}{c}6.39 \pm 0.17 ; 12 \\
6.11-6.68 \\
\end{array}$ & - & - & $6.69 ; 1$ & $\begin{array}{c}7.39 \pm 0.22 ; 7 \\
7.04-7.77 \\
\end{array}$ & $\begin{array}{c}7.08 \pm 0.33 ; 14 \\
6.63-7.63 \\
\end{array}$ & $\begin{array}{c}7.89 \pm 0.43 ; 3 \\
7.56-8.38 \\
\end{array}$ \\
\hline $\mathbf{M}^{3} \mathbf{M}^{3}$ & $\begin{array}{c}8.72 \pm 0.22 ; 6 \\
8.36-9.03\end{array}$ & $\begin{array}{c}8.45 \pm 0.26 ; 14 \\
7.95-8.89\end{array}$ & $\begin{array}{c}8.32 \pm 0.21 ; 8 \\
8.00-8.63\end{array}$ & $\begin{array}{c}8.39 \pm 0.14 ; 12 \\
8.11-8.63\end{array}$ & - & - & $8.95 ; 1$ & $\begin{array}{c}9.72 \pm 0.28 ; 7 \\
9.29-10.12 \\
\end{array}$ & $\begin{array}{c}9.51 \pm 0.49 ; 14 \\
8.79-10.36 \\
\end{array}$ & $\begin{array}{c}9.81 \pm 0.31 ; 3 \\
9.63-10.16 \\
\end{array}$ \\
\hline $\mathrm{CM}^{3}$ & $\begin{array}{c}6.62 \pm 0.09 ; 6 \\
6.49-6.77\end{array}$ & $\begin{array}{c}6.52 \pm 0.19 ; 14 \\
6.35-6.99\end{array}$ & $\begin{array}{c}6.52 \pm 0.14 ; 8 \\
6.34-6.75\end{array}$ & $\begin{array}{c}6.58 \pm 0.16 ; 12 \\
6.30-6.84\end{array}$ & - & - & $7.26 ; 1$ & $\begin{array}{c}7.55 \pm 0.13 ; 7 \\
7.32-7.68\end{array}$ & $\begin{array}{c}7.26 \pm 0.44 ; 14 \\
6.72-7.94\end{array}$ & $\begin{array}{c}7.74 \pm 0.23 ; 3 \\
7.59-8.00\end{array}$ \\
\hline ML & $\begin{array}{c}13.69 \pm 0.13 ; 6 \\
13.49-13.82 \\
\end{array}$ & $\begin{array}{c}13.75 \pm 0.22 ; 14 \\
13.41-14.13 \\
\end{array}$ & $\begin{array}{c}13.72 \pm 0.26 ; 8 \\
13.32-14.10 \\
\end{array}$ & $\begin{array}{c}13.41 \pm 0.24 ; 12 \\
13.09-13.90 \\
\end{array}$ & - & - & $14.89 ; 1$ & $\begin{array}{c}15.86 \pm 0.32 ; 7 \\
15.34-16.24 \\
\end{array}$ & $\begin{array}{c}15.51 \pm 1.05 ; 15 \\
14.14-17.00 \\
\end{array}$ & $\begin{array}{c}15.81 \pm 0.62 ; 3 \\
15.25-16.47 \\
\end{array}$ \\
\hline $\mathrm{CM}_{3}$ & $\begin{array}{c}7.53 \pm 0.17 ; 6 \\
7.30-7.80 \\
\end{array}$ & $\begin{array}{c}7.42 \pm 0.21 ; 14 \\
7.09-7.88 \\
\end{array}$ & $\begin{array}{c}7.36 \pm 0.17 ; 8 \\
7.12-7.67 \\
\end{array}$ & $\begin{array}{c}7.36 \pm 0.11 ; 12 \\
7.20-7.56\end{array}$ & - & - & $7.92 ; 1$ & $\begin{array}{c}8.65 \pm 0.20 ; 7 \\
8.37-8.89 \\
\end{array}$ & $\begin{array}{c}8.28 \pm 0.47 ; 15 \\
7.63-8.96 \\
\end{array}$ & $\begin{array}{c}8.79 \pm 0.33 ; 3 \\
8.57-9.17 \\
\end{array}$ \\
\hline
\end{tabular}


1110 See Material and Methods for acronyms of museums and genetic markers. ${ }^{(\dagger)}$ - tissue samples only. ${ }^{(*)}$-Localities for specimens included in 1111 molecular analyses are indicated by numbers (after colon) as shown in Figure 1. Country codes include: IN - India, KH - Cambodia; LA - Laos; 1112 and VN - Vietnam. (\$) - Numbers (in parentheses) after Genbank accession numbers for Cytb and COI sequences of Scotophilus specimens are

1113 respective haplotypes shown in Figure 1 and 2.

\begin{tabular}{|c|c|c|c|c|c|c|}
\hline \multirow{2}{*}{ Taxon } & \multirow{2}{*}{ Museum/Sample code } & \multirow{2}{*}{ Location $^{(\star)}$} & \multicolumn{4}{|c|}{ Genbank Accession No. } \\
\hline & & & $C y t b^{(\S)}$ & $\mathrm{COI}(\S)$ & TUFM & ZFYVE27 \\
\hline S. heathii $\left({ }^{\lambda}\right)$ & HNHM 65.23.1. & Bharatpur, Rajasthan, IN & - & - & - & - \\
\hline S. heathii () & HNHM 92.120.1. (11951) & Elephanta caves, Mumbai, Maharashtra, IN & - & - & - & - \\
\hline S. heathii $\left({ }^{\lambda}\right)$ & HNHM 93.36.1. (12175) & Coimbatore, Tamil Nadu, IN & - & - & - & - \\
\hline S. heathii $\left({ }^{\lambda}\right)$ & HNHM 93.37.1. (12207) & Sevoke, IN & - & - & - & - \\
\hline S. heathii $\left({ }^{\lambda}\right)$ & HNHM 92.119.1. (11526) & N.Salt Lake, Nalbani, BD & - & - & - & - \\
\hline S. heathii $(\widehat{\jmath})$ & IEBR.Tu.04.09.09.1 (T5028) & Xom Hau, Dong Anh, Hanoi, VN: 10 & - & MT821518 (6) & - & - \\
\hline S. heathii (ㅇ) & IEBR.Tu.10.08.09.1 (T5029) & Ho Tay, Tay Ho, Ha Noi, VN: 10 & - & MT821519 (8) & - & - \\
\hline S. heathii (ㅇ) & IEBR.VN15-47 (VN6149) & Xom Hau, Dong Anh, Hanoi, VN: 10 & MT820603 (2) & MT821506 (9) & - & - \\
\hline S. heathii $\left({ }^{\widehat{1}}\right)$ & IEBR.VN15-49 (VN6151) & Xom Hau, Dong Anh, Hanoi, VN: 10 & MT820604 (2) & MT821505 (9) & - & - \\
\hline S. heathii (ㅇ) & IEBR.VN15-50 (VN6152) & Xom Hau, Dong Anh, Hanoi, VN: 10 & MT820605 (2) & MT821504 (8) & - & - \\
\hline S. heathii (ㅇ) & IEBR.VN11-0712 & Ngoc Lac, Thanh Hoa, VN: 11 & - & MT821517 (7) & - & - \\
\hline S. heathii (ㅇ) & IEBR.PH24 (VN7297) & Pu Huong, Nghe An, VN & - & - & - & - \\
\hline S. heathii $\left({ }^{\lambda}\right)$ & CBC01250 (VN11-1648) & Preah Vihear protected forest, KH: 18 & - & MT821520 (10) & - & - \\
\hline S. heathii (ㅇ) & CBC01251 & Preah Vihear protected forest, KH: 18 & - & - & - & - \\
\hline S. heathii (ㅇ) & CBC01252 (VN11-1649) & Preah Vihear protected forest, KH: 18 & - & MT821521(10) & - & - \\
\hline S. heathii (ㅇ) & $\mathrm{CBC} 01260$ & Preah Vihear protected forest, KH: 18 & - & - & - & - \\
\hline S. heathii $\left({ }^{\lambda}\right)$ & HNHM 2014.11.26 (23702) & Preah Vihear protected forest, $\mathrm{KH}$ & - & - & - & - \\
\hline
\end{tabular}




\begin{tabular}{|c|c|c|c|c|c|c|}
\hline \multirow{2}{*}{ Taxon } & \multirow{2}{*}{ Museum/Sample code } & \multirow{2}{*}{ Location $^{(\ddagger)}$} & \multicolumn{4}{|c|}{ Genbank Accession No. } \\
\hline & & & $C y t b^{(\S)}$ & $\mathrm{COI}{ }^{(\S)}$ & TUFM & ZFYVE27 \\
\hline S. heathii (+) & IEBR.M4547 & Ba To, Quang Ngai, VN: 19 & - & - & - & - \\
\hline S. heathii $($ 욱) & IEBR.M4548 & Ba To, Quang Ngai, VN: 19 & - & - & - & - \\
\hline S. heathii $\left(ठ^{\lambda}\right)$ & IEBR.M4550 (VN7293) & Ba To, Quang Ngai, VN: 19 & - & - & - & - \\
\hline S. heathii $\left(ठ^{\lambda}\right)$ & IEBR.M4553 (VN1736/VN7294) & Ba To, Quang Ngai, VN: 19 & MT820609 (6) & MT821522 (18) & MT820615 & MT820621 \\
\hline S. heathii (ㅇ) & IEBR.M4554 (VN7295) & Ba To, Quang Ngai, VN: 19 & MT820611 (7) & MT821507 (16) & & \\
\hline S. heathii (ठ̊) & IEBR.M4555 (VN1737/VN7296) & Ba To, Quang Ngai, VN: 19 & MT820610 (6) & MT821523 (18) & MT820616 & MT820622 \\
\hline S. heathii $(+)$ & IEBR.VN17-532 (VN7299) & Loi Hai, Ninh Thuan, VN: 21 & MT820606 (3) & MT821509 (12) & - & - \\
\hline S. heathii $\left(ठ^{\Uparrow}\right)$ & IEBR.VN17-533 (VN7300) & Loi Hai, Ninh Thuan, VN: 21 & MT820607 (3) & MT821510 (12) & - & - \\
\hline S. heathii $(+)$ & IEBR.VN17-536 (VN7302) & Loi Hai, Ninh Thuan, VN: 21 & MT820608 (5) & MT821508 (13) & - & - \\
\hline S. heathii $(+)$ & IEBR.VN17-537 & Lien Huong, Binh Thuan, VN & - & - & - & - \\
\hline S. heathii $\left(ठ^{\Uparrow}\right)$ & IEBR.VN17-538 (VN7303) & Lien Huong, Binh Thuan, VN & - & - & - & - \\
\hline S. heathii (?) & IEBR.Tu.18.5.17.2 & Lien Huong, Binh Thuan, VN & - & - & - & - \\
\hline S. heathii $\left(ठ^{\Uparrow}\right)$ & IEBR.Tu.18.5.17.3 & Lien Huong, Binh Thuan, VN & - & - & - & - \\
\hline S. kuhlii $\left(\bigcirc^{\Uparrow}\right)$ & HNHM 92.121.1. (11548) & Calcutta, West Bengal, IN & - & - & - & - \\
\hline S. kuhlii (ठ) & HNHM 92.123.1. (11600) & Calcutta, West Bengal, IN & - & - & - & - \\
\hline S. kuhlii (ठ) & HNHM 92.123.2. (11601) & Calcutta, West Bengal, IN & - & - & - & - \\
\hline S. kuhlii $\left(ठ^{\Uparrow}\right)$ & HNHM 92.123.3. (11602) & Calcutta, West Bengal, IN & - & - & - & - \\
\hline S. kuhlii (ठَ) & HNHM 92.123.4. (11603) & Calcutta, West Bengal, IN & - & - & - & - \\
\hline S. kuhlii $\left({ }^{\Uparrow}\right)$ & HNHM 92.123.5. (11604) & Calcutta, West Bengal, IN & - & - & - & - \\
\hline S. kuhlii $\left({ }_{0}^{\Uparrow}\right)$ & HNHM 92.123.6. (11605) & Calcutta, West Bengal, IN & - & - & - & - \\
\hline S. kuhlii (ठ) & HNHM 92.155.1. (11606) & Calcutta, West Bengal, IN & - & - & - & - \\
\hline S. kuhlii (ठ) & HNHM 92.123.7. (11608) & Calcutta, West Bengal, IN & - & - & - & - \\
\hline S. kuhlii $\left(ठ^{\Uparrow}\right)$ & HNHM 92.123.8. (11609) & Calcutta, West Bengal, IN & - & - & - & - \\
\hline
\end{tabular}




\begin{tabular}{|c|c|c|c|c|c|c|}
\hline \multirow{2}{*}{ Taxon } & \multirow{2}{*}{ Museum/Sample code } & \multirow{2}{*}{ Location $^{(\$)}$} & \multicolumn{4}{|c|}{ Genbank Accession No. } \\
\hline & & & $C y t b^{(\S)}$ & $C O I^{(\S)}$ & TUFM & ZFYVE27 \\
\hline S. kuhlii (ठ̂) & HNHM 93.34.1. (12100) & Ganespur, West Bengal, IN & - & - & - & - \\
\hline S. kuhlii () & HNHM 93.35.1. (12176) & Mettupalayam, Tamil Nadu, IN & - & - & - & - \\
\hline S. kuhlii $\left(\delta^{1}\right)$ & HNHM 92.122.1. (11565) & Ruined Hindu temple, Konarka, Orissa, IN & - & - & - & - \\
\hline S. kuhlii $(ठ)$ & MM3297(†) & Nay Pyi Daw, Myanmar: 7 & MT820592 (9) & - & - & - \\
\hline S. kuhlii $\left(ठ^{\Uparrow}\right)$ & MM3298(†) & Nay Pyi Daw, Myanmar: 7 & MT820576 (3) & - & - & - \\
\hline S. kuhlii $(+)$ & MM3300(†) & Nay Pyi Daw, Myanmar: 7 & MT820593 (9) & - & - & - \\
\hline S. kuhlii $(+)$ & ${\mathrm{MM} 3301^{(\dagger)}}^{(\dagger)}$ & Nay Pyi Daw, Myanmar: 7 & MT820577 (4) & - & - & - \\
\hline S. kuhlii () & MM3302(†) & Nay Pyi Daw, Myanmar: 7 & MT820583 (8) & - & - & - \\
\hline S. kuhlii () & MM3303(†) & Nay Pyi Daw, Myanmar: 7 & MT820594 (9) & - & - & - \\
\hline S. kuhlii $\left(ठ^{\Uparrow}\right)$ & MM3304(†) & Nay Pyi Daw, Myanmar: 7 & MT820578 (1) & - & - & - \\
\hline S. kuhlii () & MM3305(†) & Nay Pyi Daw, Myanmar: 7 & MT820579 (1) & - & - & - \\
\hline S. kuhlii (ㅇ) & UTHF.MM3168B1 & Nay Pyi Daw, Myanmar: 7 & MT820584 (9) & MT821492 (3) & - & - \\
\hline S. kuhlii $\left({ }^{\Uparrow}\right)$ & UTHF.MM3169B2 & Nay Pyi Daw, Myanmar: 7 & MT820581 (6) & MT821503 (5) & - & - \\
\hline S. kuhlii $(ð)$ & UTHF.MM3170B3 & Nay Pyi Daw, Myanmar: 7 & MT820575 (2) & MT821491 (6) & - & - \\
\hline S. kuhlii $\left(ठ^{\Uparrow}\right)$ & UTHF.MM3171B4 & Nay Pyi Daw, Myanmar: 7 & MT820585 (9) & MT821502 (7) & - & - \\
\hline S. kuhlii () & UTHF.MM3172B5 & Nay Pyi Daw, Myanmar: 7 & MT820586 (9) & MT821499 (3) & - & - \\
\hline S. kuhlii (q) & UTHF.MM3173B6 & Nay Pyi Daw, Myanmar: 7 & Unassigned (9) & MT821498 (3) & - & - \\
\hline S. kuhlii (ㅇ) & UTHF.MM3174B7 & Nay Pyi Daw, Myanmar: 7 & MT820587 (9) & MT821500 (4) & - & - \\
\hline S. kuhlii (ㅇ) & UTHF.MM3175B8 & Nay Pyi Daw, Myanmar: 7 & MT820574 (1) & MT821490 (2) & - & - \\
\hline S. kuhlii (우) & UTHF.MM3176B9 & Nay Pyi Daw, Myanmar: 7 & MT820588 (9) & MT821497 (3) & - & - \\
\hline S. kuhlii (ㅇ) & UTHF.MM3182B13 & Nay Pyi Daw, Myanmar: 7 & MT820589 (9) & MT821496 (3) & - & - \\
\hline S. kuhlii (ㅇ) & UTHF.MM3183B14 & Nay Pyi Daw, Myanmar: 7 & MT820590 (9) & MT821495 (3) & - & - \\
\hline S. kuhlii (ㅇ) & UTHF.MM3184B15 & Nay Pyi Daw, Myanmar: 7 & MT820591 (9) & MT821501 (7) & - & - \\
\hline
\end{tabular}




\begin{tabular}{|c|c|c|c|c|c|c|}
\hline \multirow{2}{*}{ Taxon } & \multirow{2}{*}{ Museum/Sample code } & \multirow{2}{*}{ Location $^{(\ddagger)}$} & \multicolumn{4}{|c|}{ Genbank Accession No. } \\
\hline & & & Cytb $^{(\S)}$ & $\mathrm{COI}^{(\S)}$ & TUFM & ZFYVE27 \\
\hline S. kuhlii (q) & UTHF.MM3185B16 & Nay Pyi Daw, Myanmar: 7 & MT820582 (7) & MT821494 (3) & - & - \\
\hline S. kuhlii (q) & UTHF.MM3186B17 & Nay Pyi Daw, Myanmar: 7 & MT820580 (5) & MT821493 (3) & - & - \\
\hline S. kuhlii $(ठ)$ & IEBR.Tu.04.05.10.1 (T5000) & Xom Hau, Dong Anh, Hanoi, VN: 10 & - & MT821515 (16) & MT820617 & MT820623 \\
\hline S. kuhlii $\left({ }^{\Uparrow}\right)$ & IEBR.Tu.04.09.09.3 (T5001) & Xom Hau, Dong Anh, Hanoi, VN: 10 & - & MT821516 (16) & - & - \\
\hline S. kuhlii $\left({ }^{\Uparrow}\right)$ & IEBR.VN15-43 (VN6145) & Xom Hau, Dong Anh, Hanoi, VN: 10 & MT820599 (15) & MT821486 (16) & - & - \\
\hline S. kuhlii (ठ) & VN15-44 (VN6146) $)^{(\dagger)}$ & Xom Hau, Dong Anh, Hanoi, VN: 10 & MT820597 (13) & MT821488 (15) & - & - \\
\hline S. kuhlii (ठ) & IEBR.VN15-45 (VN6147) & Xom Hau, Dong Anh, Hanoi, VN: 10 & MT820596 (12) & MT821489 (15) & - & - \\
\hline S. kuhlii $\left({ }^{\Uparrow}\right)$ & IEBR.VN15-51 (VN6153) & Xom Hau, Dong Anh, Hanoi, VN: 10 & MT820598 (14) & MT821487 (16) & - & - \\
\hline S. kuhlii (ठ) & IEBR.VN17-46 (VN7397) & Xom Hau, Dong Anh, Hanoi, VN: 10 & - & Unassigned (16) & - & - \\
\hline S. kuhlii $\left(ठ^{\Uparrow}\right)$ & HNHM 98.46.1. (16574) & Vientiane, LA & - & - & - & - \\
\hline S. kuhlii (q) & IEBR.VN17-355 (VN7298) & Loi Hai, Ninh Thuan, VN: 21 & - & - & - & - \\
\hline S. kuhlii (q) & IEBR.VN17-534 (VN7301) & Loi Hai, Ninh Thuan, VN: 21 & MT820595 (11) & MT821482 (14) & & \\
\hline S. kuhlii (ठ) & IEBR.VN17-539 (VN7304) & Lien Huong, Binh Thuan, VN & - & - & - & - \\
\hline S. kuhlii (?) & IEBR.Tu.18.5.17.1 & Lien Huong, Binh Thuan, VN & - & - & - & - \\
\hline S. kuhlii (q) & IEBR.VN19-04 & Vinh Loi, Bac Lieu, VN & - & - & - & - \\
\hline S. kuhlii (ㅇ) & IEBR.VN19-05 & Vinh Loi, Bac Lieu, VN & - & - & - & - \\
\hline S. kuhlii (ㅇ) & IEBR.VN19-06 & Vinh Loi, Bac Lieu, VN & - & - & - & - \\
\hline S. kuhlii $(+)$ & IEBR.VN19-07 & Vinh Loi, Bac Lieu, VN & - & - & - & - \\
\hline S. kuhlii $(q)$ & IEBR.VN19-08 & Vinh Loi, Bac Lieu, VN & - & - & - & - \\
\hline S. kuhlii (ㅇ) & IEBR.VN19-09 & Vinh Loi, Bac Lieu, VN & - & - & - & - \\
\hline S. kuhlii $(q)$ & IEBR.VN19-10 & Vinh Loi, Bac Lieu, VN & - & - & - & - \\
\hline S. kuhlii (q) & IEBR.VN19-11 & Vinh Loi, Bac Lieu, VN & - & - & - & - \\
\hline S. kuhlii (q) & IEBR.VN19-12 & Vinh Loi, Bac Lieu, VN & - & - & - & - \\
\hline
\end{tabular}




\begin{tabular}{|c|c|c|c|c|c|c|}
\hline \multirow{2}{*}{ Taxon } & \multirow{2}{*}{ Museum/Sample code } & \multirow{2}{*}{ Location } & \multicolumn{4}{|c|}{ Genbank Accession No. } \\
\hline & & & $C y t b^{(\S)}$ & $\mathrm{COI}(\S)$ & TUFM & ZFYVE27 \\
\hline S. kuhlii (ㅇ) & IEBR.VN19-13 & Vinh Loi, Bac Lieu, VN & - & - & - & - \\
\hline S. kuhlii (ठ̂) & IEBR.VN19-14 & Vinh Loi, Bac Lieu, VN & - & - & - & - \\
\hline S. kuhlii (ㅇ) & IEBR.VN19-15 & Vinh Loi, Bac Lieu, VN & - & - & - & - \\
\hline S. kuhlii (ठ̂) & $\mathrm{CBC} 01861$ & Bang Chureng, S'ang, Kandal, KH: 25 & - & - & - & - \\
\hline S. kuhlii (ㅇ) & CBC01862 & Bang Chureng, S’ang, Kandal, KH: 25 & - & - & - & - \\
\hline S. kuhlii (ㅇ) & $\mathrm{CBC} 01863$ & Bang Chureng, S'ang, Kandal, KH: 25 & - & - & - & - \\
\hline S. kuhlii (ㅇ) & $\mathrm{CBC} 01864$ & Bang Chureng, S'ang, Kandal, KH: 25 & - & - & - & - \\
\hline S. kuhlii (ठ̂) & $\mathrm{CBC} 01865$ & Bang Chureng, S'ang, Kandal, KH: 25 & - & - & - & - \\
\hline S. kuhlii (ठ゚) & CBC01866 (VN11-1642) & Bang Chureng, S'ang, Kandal, KH: 25 & - & MT821512 (12) & - & - \\
\hline S. kuhlii (ठ̂) & CBC01867 (VN11-1640) & Bang Chureng, S'ang, Kandal, KH: 25 & - & MT821513 (11) & - & - \\
\hline S. kuhlii (ठ̂) & CBC01870 (VN11-1641) & Prey Toch, Moung Russey, Battambang, KH: 26 & - & MT821514 (11) & - & - \\
\hline S. kuhlii (ठ゚) & CBC01871 (VN11-1639) & Prey Toch, Moung Russey, Battambang, KH: 26 & - & MT821511 (1) & MT820617 & MT820624 \\
\hline S. kuhlii (ठ゚) & HNHM 98.14.27. (15672) & Selangor, Malaysia & - & - & - & - \\
\hline S. kuhlii (ठ゚) & UPLB-MNH paa1548 (MT1706) & Quezon city, Luzon Island, Philippines: 28 & MT820600 (17) & MT821484 (16) & - & - \\
\hline S. kuhlii (ठ̂) & UPLB-MNH paa1550 (MT1707) & Quezon city, Luzon Island, Philippines: 28 & MT820601 (17) & MT821483 (16) & - & - \\
\hline S. kuhlii (ㅇ) & UPLB-MNH paa1552 (MT1709) & Quezon city, Luzon Island, Philippines: 28 & MT820602 (17) & MT821485 (16) & - & - \\
\hline S. kuhlii (ठ̊) & UPLB-MNH jdva1064 (3873) & Sibuyan Island, Philippines & - & - & - & - \\
\hline S. kuhlii (ㅇ) & UPLB-MNH jdva1065 (3874) & Sibuyan Island, Philippines & - & - & - & - \\
\hline S. kuhlii (ㅇ) & UPLB-MNH jdva1066 (3875) & Sibuyan Island, Philippines & - & - & - & - \\
\hline S.? solutatus & HNHM 2869.22 (ori. ID: S. kuhlii) & Java, Indonesia & - & - & - & - \\
\hline
\end{tabular}




\section{SUPPORTING INFORMATION}

\section{Integrative taxonomy and biogeography of Asian yellow house bats (Vespertilionidae: Scotophilus) in the Indomalayan Region}

Vuong Tan Tu, Tamás Görföl, Gábor Csorba, Satoru Arai, Fuka Kikuchi, Dai Fukui, Daisuke Koyabu, Neil M. Furey, Saw Bawm, Kyaw San Lin, Phillip Alviola, Chu Thi Hang, Nguyen Truong Son, Tran Anh Tuan, and Alexandre Hassanin

\section{List of Alignments}

Alignment S1. Alignment of COI sequences included in the TCS analysis.

Alignment S2. Alignment of Cytb sequences included in the TCS analysis.

Alignment S3. Alignment of COI sequences included in the phylogenetic analyses.

Alignment S4. Alignment of Cytb sequences included in the phylogenetic analyses.

Alignment S5. Alignment of TuFM sequences included in the phylogenetic analyses.

Alignment S6. Alignment of ZFYVE27 sequences included in the phylogenetic analyses.

Alignment S7. Alignment of nuDNA sequences (combining TuFM and ZFYVE27 genes)

included in the phylogenetic analyses.

\section{List of Tables}

Table S1. List of species and subspecies of the Asian Scotophilus described as new to science prior to the mid-20 $0^{\text {th }}$ century.

Table S2. Genetic sequences of Asian Scotophilus spp. and outgroups in GenBank included in molecular analyses in the present study.

Table S3. Primers used to amplify and sequence DNA in the present study.

Table S4. mtDNA divergence within Asian Scotophilus spp.

Table S5. COI genetic variation in three clusters of geographic populations of S. heathii s.1..

Table S6. Factor loading for two first PCs obtained from PCA of cranial characters.

Table S7. Pairwise comparisons (ANOVA-tests) of morphometrics among geographical populations of $S$. heathii s.1. in Indochina. 


\section{List of Figures}

Figure S1: Mantel tests for isolation by distance effects on pairwise genetic divergences among geographic populations of studied Scotophilus spp

Figure S2. ML trees of Asian Scotophilus spp. and outgroups reconstructed from COI, Cytb and nuDNA sequences.

Figure S3. Bayesian trees of Asian Scotophilus spp. and outgroups reconstructed from TUFM and $Z F Y V E 27$ sequences.

Figure S4. Bayesian skyline plot representing historical demographic trends in S. kuhlii (above) and $S$. heathii (below).

Figure S5. Correlation between mean PC1's scores from PCA of skull characters and FA values of Asian Scotophilus spp.

\section{* References cited in the Supporting Information}


Table S1. List of species and subspecies of Asian Scotophilus described as new to science prior to the mid-20 ${ }^{\text {th }}$ century.

\begin{tabular}{|c|c|c|c|c|}
\hline No. & Taxa & FA (in mm) & Type locality & Reference \\
\hline 1 & S. kuhlii & 41 (immature) & ?, India & Leach, 1821 \\
\hline 2 & Vespertilio temminckii & $47-51$ (small) & Java & Horsfield, 1824 \\
\hline 3 & Nycticejus heathii & $>V$. temminckii & Mandas, Continental India & Horsfield, 1831 \\
\hline 4 & Vespertilio belangeri & 55.9 & Pondicharry, Coromandel, India & Geoffroy I., 1834 \\
\hline 5 & Scotophilus fulvus & Unknown & $?$, Java & Gray, 1843 \\
\hline 6 & Nycticejus luteus & large & Bengal, Coromandel & Blyth, 1851 \\
\hline 7 & Nycticejus castaneus & $=N$. temminckii & Malacca & Horsfield, 1851 \\
\hline 8 & Nycticejus flaveolus & Large & Continental India & Horsfield, 1851 \\
\hline 9 & Nycticejus (?) swinhoei & 50.8 & Amoy (=Xiamen), China & Blyth, 1860 \\
\hline 10 & Scotophilus wroughtoni & 50 & Kim (Surat), India & Thomas, 1897 \\
\hline 11 & Scotophilus castaneus consobrinus & $50-52$ & Hainan Is. China & Allen, 1906 \\
\hline 12 & S. kuhlii insularis & $64-67$ & Hainan Is. China & Allen, 1906 \\
\hline 13 & Scotophilus gairdneri & 48 & Paknampo, Central Siam & Kloss, 1917 \\
\hline 14 & Pachyotis temminckii panayensis & 48 & Panay Island, Philippines & Sody, 1928 \\
\hline 15 & Pachyotis temminckii celebensis & $63.5-64$ & Toli-toli, Celebes & Sody, 1928 \\
\hline 16 & Scotophilus temminckii collinus & $48-54$ & Bali & Sody, 1936 \\
\hline 17 & Scotophilus castaneus solutatus & 50-56; holotype (55) & Tjandiroto, East Java & Sody, 1936 \\
\hline
\end{tabular}


Table S2. Genetic sequences of Asian Scotophilus spp. and outgroups in GenBank included in molecular analyses in the present study.

(†) - Locations of specimens included in molecular analyses are indicated by numbers (after colon) as representing in Figure 1 . Country codes include: IN - India, KH - Cambodia; LA - Laos; and VN - Vietnam. ${ }^{(*)}$ - Numbers (in parentheses) after Genbank accession numbers for Cytb and COI sequences of studied Scotophilus specimens are respective haplotypes representing in Figures 1 and 2 . Reference ${ }^{(\S)}: 1-$ Francis et al., 2010; 2 - Ikram et al., unpublished; 3 - Kruskop et al., unpublished; 4 -Rahman \& Choudhury, unpublished; 5 - Srinivasulu et al., unpublished; 6 - Tan et al., 2020; 7 - Trujillo et al., 2009; 8 - Tu et al., 2014; 9 - Tu et al., 2017; and 10 - Tu et al., 2018.

\begin{tabular}{|c|c|c|c|c|c|c|}
\hline \multirow{2}{*}{ Taxon } & \multirow{2}{*}{ Location } & \multicolumn{4}{|c|}{ Genbank Accession No. } & \multirow{2}{*}{$\operatorname{Ref}^{(\S)}$} \\
\hline & & $C y t b^{(\ddagger)}$ & $\mathrm{COI}^{(\ddagger)}$ & TUFM & ZFYVE27 & \\
\hline M. cyclotis & Ngoc Linh, Kon Tum, VN & MH137367 & KF772775 & MH137554 & MH137584 & {$[8,10]$} \\
\hline E. pachyomus & Copia, Son La, VN & KX496340 & KX496341 & KX496347 & KX496346 & [9] \\
\hline S. heathii & Kohat, Khyber Pakhtunkhwa, Pakistan: 1 & - & MG550115 (5) & - & - & {$[2]$} \\
\hline S. heathii & Swabi, Khyber Pakhtunkhwa, Pakistan: 2 & - & MH712738 (1) & - & - & {$[2]$} \\
\hline S. heathii & Swabi, Khyber Pakhtunkhwa, Pakistan: 2 & - & MH716035 (2) & - & - & [2] \\
\hline S. heathii & Fateh Jang, Attock, Punjab, Pakistan: 3 & - & MG199233 (4) & - & - & {$[2]$} \\
\hline S. heathii & Fateh Jang, Attock, Punjab, Pakistan: 3 & - & MG199234 (4) & - & - & {$[2]$} \\
\hline S. heathii & Fateh Jang, Attock, Punjab, Pakistan: 3 & - & MG199235 (4) & - & - & {$[2]$} \\
\hline S. heathii & Fateh Jang, Attock, Punjab, Pakistan: 3 & - & MG199236 (4) & - & - & {$[2]$} \\
\hline S. heathii & Fateh Jang, Attock, Punjab, Pakistan: 3 & - & MG199237 (4) & - & - & {$[2]$} \\
\hline S. heathii & Fateh Jang, Attock, Punjab, Pakistan: 3 & - & MG199238 (4) & - & - & {$[2]$} \\
\hline S. heathii & Fateh Jang, Attock, Punjab, Pakistan: 3 & - & MG199240 (4) & - & - & {$[2]$} \\
\hline S. heathii & Fateh Jang, Attock, Punjab, Pakistan: 3 & - & MG199241 (4) & - & - & {$[2]$} \\
\hline
\end{tabular}




\begin{tabular}{|c|c|c|c|c|c|c|}
\hline \multirow{2}{*}{ Taxon } & \multirow{2}{*}{ Location (i) } & \multicolumn{4}{|c|}{ Genbank Accession No. } & \multirow{2}{*}{$\operatorname{Ref}^{(\S)}$} \\
\hline & & $C y t b^{(\ddagger)}$ & $C O I^{(\ddagger)}$ & TUFM & ZFYVE27 & \\
\hline S. heathii & Fateh Jang, Attock, Punjab, Pakistan: 3 & - & MG199242 (4) & - & - & [2] \\
\hline S. heathii & Fateh Jang, Attock, Punjab, Pakistan: 3 & - & MG544111 (4) & - & - & {$[2]$} \\
\hline S. heathii & Fateh Jang, Attock, Punjab, Pakistan: 3 & - & MG550114 (4) & - & - & {$[2]$} \\
\hline S. heathii & Fateh Jang, Attock, Punjab, Pakistan: 3 & - & MG199239 (4) & - & - & {$[2]$} \\
\hline S. heathii & Fateh Jang, Attock, Punjab, Pakistan: 3 & - & MF495678 (4) & - & - & {$[2]$} \\
\hline S. heathii & Fateh Jang, Attock, Punjab, Pakistan: 3 & - & MG299068 (4) & - & - & {$[2]$} \\
\hline S. heathii & Hampi, Bellary, Karnataka, IN: 5 & - & MG821185 (3) & - & - & {$[5]$} \\
\hline S. heathii & -, Yunnan, China: 8 & EU750946 (1) & - & - & - & [7] \\
\hline S. heathii & Nam Et national protected area, LA: 9 & - & HM541921 (7) & - & - & [1] \\
\hline S. heathii & Nam Et national protected area, LA: 9 & - & HM541922 (7) & - & - & [1] \\
\hline S. heathii & Tam Dao, Vinh Phuc, VN: 12 & EU750945 (2) & - & - & - & [7] \\
\hline S. heathii & Ban Paam, Attapu, LA: 16 & - & HM541920 (11) & - & - & [1] \\
\hline S. heathii & Ban Paam, Attapu, LA: 16 & - & HM541923 (17) & - & - & [1] \\
\hline S. heathii & Dong Hua Sao, Champasak, LA: 17 & - & HM541924 (14) & - & - & [1] \\
\hline S. heathii & Dong Hua Sao, Champasak, LA: 17 & - & HM541925 (14) & - & - & {$[1]$} \\
\hline S. heathii & Yok Don NP, Dak Lak, VN: 20 & - & HM541926 (15) & - & - & {$[1]$} \\
\hline S. heathii & Yok Don NP, Dak Lak, VN: 20 & EU750944 (3) & - & - & - & [7] \\
\hline S. kuhlii & Tadlapet, Adilabad, Telangana, IN: 5 & - & MG821195 (7) & - & - & {$[5]$} \\
\hline S. kuhlii & Cachar, Assam, IN: 6 & - & KT291764 (7) & - & - & {$[4]$} \\
\hline S. kuhlii & Tam Dao, Vinh Phuc, VN: 12 & EU750931 (16) & - & - & - & [7] \\
\hline
\end{tabular}




\begin{tabular}{|c|c|c|c|c|c|c|}
\hline \multirow{2}{*}{ Taxon } & \multirow{2}{*}{ Location $\stackrel{(\dagger)}{ }$} & \multicolumn{4}{|c|}{ Genbank Accession No. } & \multirow{2}{*}{$\operatorname{Ref}^{(\S)}$} \\
\hline & & $C y t b^{(\ddagger)}$ & $C O I^{(\ddagger)}$ & TUFM & ZFYVE27 & \\
\hline S. kuhlii & Tam Dao, Vinh Phuc, VN: 12 & EU750913 (13) & - & - & - & [7] \\
\hline S. kuhlii & -, Guangxi, China: 13 & LC426467 (18) & - & - & - & {$[6]$} \\
\hline S. kuhlii & -, Guangxi, China: 14 & LC426465 (17) & - & - & - & {$[6]$} \\
\hline S. kuhlii & -, Guangxi, China: 14 & LC426466 (17) & - & - & - & [6] \\
\hline S. kuhlii & -, Guangxi, China: 14 & LC426468 (17) & - & - & - & [6] \\
\hline S. kuhlii & Savannakhet, LA: 15 & - & HM541934 (16) & - & - & [1] \\
\hline S. kuhlii & Cat Tien, Lam Dong, VN: 22 & - & HM541935 (17) & - & - & {$[1]$} \\
\hline S. kuhlii & Cat Tien, Lam Dong, VN: 22 & - & HM541936 (19) & - & - & [1] \\
\hline S. kuhlii & Cat Tien, Lam Dong, VN: 22 & EU750924 (24) & - & - & - & [7] \\
\hline S. kuhlii & Cat Tien, Lam Dong, VN: 22 & - & HM541937 (13) & - & - & [1] \\
\hline S. kuhlii & Cat Tien, Lam Dong, VN: 22 & EU750925 (10) & - & - & - & [7] \\
\hline S. kuhlii & Cat Tien, Lam Dong, VN: 22 & - & HM541938 (11) & - & - & [1] \\
\hline S. kuhlii & Cat Tien, Lam Dong, VN: 22 & EU750926 (20) & - & - & - & [7] \\
\hline S. kuhlii & Cat Tien, Lam Dong, VN: 22 & - & HM541940 (9) & - & - & [1] \\
\hline S. kuhlii & Cat Tien, Lam Dong, VN: 22 & - & JF444113 (10) & - & - & [3] \\
\hline S. kuhlii & Cat Tien, Lam Dong, VN: 22 & - & JF444114 (8) & - & - & [3] \\
\hline S. kuhlii & Cat Tien, Lam Dong, VN: 22 & EU750923 (19) & - & - & - & [7] \\
\hline S. kuhlii & Cat Tien, Lam Dong, VN: 22 & EU750927 (21) & - & - & - & [7] \\
\hline S. kuhlii & Ho Chi Minh, VN: 23 & - & HM541927 (20) & - & - & [1] \\
\hline S. kuhlii & Soc Trang, Soc Trang, VN: 24 & - & HM541929(21) & - & - & {$[1]$} \\
\hline
\end{tabular}




\begin{tabular}{|c|c|c|c|c|c|c|}
\hline \multirow{2}{*}{ Taxon } & \multirow{2}{*}{ Location $\stackrel{(\dagger)}{ }$} & \multicolumn{4}{|c|}{ Genbank Accession No. } & \multirow{2}{*}{$\operatorname{Ref}^{(\S)}$} \\
\hline & & $C y t b^{(\ddagger)}$ & $C O I^{(\ddagger)}$ & TUFM & ZFYVE27 & \\
\hline S. kuhlii & Soc Trang, Soc Trang, VN: 24 & - & HM541932 (22) & - & - & {$[1]$} \\
\hline S. kuhlii & Soc Trang, Soc Trang, VN: 24 & EU750930 (27) & - & - & - & [7] \\
\hline S. kuhlii & Soc Trang, Soc Trang, VN: 24 & - & HM541933 (21) & - & - & {$[1]$} \\
\hline S. kuhlii & Soc Trang, Soc Trang, VN: 24 & EU750929 (23) & - & - & - & {$[7]$} \\
\hline S. kuhlii & Soc Trang, Soc Trang, VN: 24 & - & HM541930 (18) & - & - & [1] \\
\hline S. kuhlii & Soc Trang, Soc Trang, VN: 24 & - & HM541931 (1) & - & - & {$[1]$} \\
\hline S. kuhlii & Jitra, Kedah State, Malaysia: 27 & EU750920 (19) & - & - & - & {$[7]$} \\
\hline S. kuhlii & Jitra, Kedah State, Malaysia: 27 & EU750922 (25) & - & - & - & [7] \\
\hline S. kuhlii & Jitra, Kedah State, Malaysia: 27 & EU750915 (26) & - & - & - & {$[7]$} \\
\hline S. kuhlii & - , Luzon Island, Philippines: 28 & EU750914 (17) & - & - & - & [7] \\
\hline
\end{tabular}


Table S3. Primers used to amplify and sequence DNA in the present study

\begin{tabular}{|c|c|c|c|}
\hline Gene & Primer sets (5'-3') & $\begin{array}{l}\text { Amplicon } \\
\text { length (bp) }\end{array}$ & Sources \\
\hline \multirow[t]{2}{*}{$C y t b$} & $\begin{array}{l}\text { Mt-L14724F: CGAGATCTGAAAAACCATCGTTG } \\
\text { Cytb-H15915R: AACTGCAGTCATCTCCGGTTTACAAGA }\end{array}$ & $\sim 1190$ & $\begin{array}{l}\text { Irwin, Kocher, } \\
\text { \& Wilson, } 1991\end{array}$ \\
\hline & $\begin{array}{l}\text { Cy-14726F: GACYARTRRCATGAAAAAYCAYCGT TGT } \\
\text { Cy- 15909R: CYYCWTYIYTGGTTTACAAGACYAG }\end{array}$ & $\sim 1180$ & Arai et al., 2016 \\
\hline \multirow[t]{2}{*}{$\overline{C O I}$} & $\begin{array}{l}\text { MammMt-5533F: CYCTGTSYTTRRATTTACAGTYYAA } \\
\text { MammMt-7159R: GRGGTTCRAWWCCTYCCTYTCTT }\end{array}$ & $\begin{array}{l}1620 \\
\sim\end{array}$ & Arai et al., 2019 \\
\hline & $\begin{array}{l}\text { UTyr: ACCYCTGTCYTTAGATTTACAGTC } \\
\text { C1L705: ACTTCDGGGTGNCCRAARAATCA }\end{array}$ & $\sim 750$ & $\begin{array}{l}\text { Hassanin et al., } \\
2013\end{array}$ \\
\hline TUFM & $\begin{array}{l}\text { TUFM-EX9U: CTGACTTGGGACATGGCCTGTCG } \\
\text { TUFM-EX10L: ACGCTGGCCTTTYTCTAAGATCAT }\end{array}$ & $\sim 700$ & $\begin{array}{l}\text { Hassanin et al., } \\
2013\end{array}$ \\
\hline ZFYVE27 & $\begin{array}{l}\text { ZFYVE27-EX6U: GAATGTGGAGTTCTTCCGAG } \\
\text { ZFYVE27-EX7L: GGGTTCATCCGCCGCTGCAGA }\end{array}$ & $\sim 750-800$ & $\begin{array}{l}\text { Hassanin et al., } \\
2013\end{array}$ \\
\hline
\end{tabular}


Table S4. mtDNA divergence within Asian Scotophilus spp.

\begin{tabular}{|l|l|l|l|l|}
\hline \multirow{2}{*}{} & \multicolumn{2}{|c|}{ S. kuhlii. s.l. } & \multicolumn{2}{c|}{ S. heathii s.I } \\
\cline { 2 - 5 } & COI (576nt) & Cytb (1140nt) & COI (576nt) & Cytb (1140nt) \\
\hline Number of locations & 13 & 10 & 13 & 6 \\
\hline Number of sequences & 43 & 46 & 39 & 12 \\
\hline Number of segregating sites & 41 & 69 & 69 & 78 \\
\hline Number of haplotypes & 22 & 27 & 18 & 7 \\
\hline Haplotype diversity $(\mathrm{Hd})$ & 0.932 & 0.922 & 0.865 & 0.879 \\
\hline Nucleotide diversity $(\pi)$ & 0.013 & 0.010 & 0.034 & 0.025 \\
\hline
\end{tabular}

Table S5. COI genetic variation in three clusters of geographic populations of $S$. heathii s.l..

S5A - mtDNA divergence within three populations of $S$. heathii.

\begin{tabular}{|l|c|c|c|}
\hline & $\begin{array}{l}\text { Indian Subcontinent } \\
\text { (Pakistan + India) }\end{array}$ & Northern Indochina & Southern Indochina \\
\hline Number of locations & 4 & 4 & 6 \\
\hline Number of sequences & 18 & 8 & 13 \\
\hline Number of segregating sites & 16 & 5 & 20 \\
\hline Number of haplotypes & 5 & 4 & 9 \\
\hline Haplotype diversity $(\mathrm{Hd})$ & 0.405 & 0.821 & 0.95 \\
\hline Nucleotide diversity $(\pi)$ & 0.0038 & 0.0035 & 0.01 \\
\hline
\end{tabular}

S5B - Molecular variance (AMOVA) of $C O I$ variation in three populations of $S$. heathii s.l..

\begin{tabular}{|l|l|l|l|l|l|l|}
\hline Source of variation & d.f. & SSD & $\begin{array}{l}\text { Variance } \\
\text { component }\end{array}$ & $\begin{array}{l}\% \\
\text { variation }\end{array}$ & F-statistics & $\begin{array}{l}\text { P } \\
\text { values }\end{array}$ \\
\hline Within populations & 36 & 24.024 & 0.334 & 68.7 & Fis $=1.000$ & 0.001 \\
\hline $\begin{array}{l}\text { Among } \\
\text { populations }\end{array}$ & 2 & 8.848 & 0.152 & 31.3 & Fst $=0.313$ & 0.001 \\
\hline
\end{tabular}

S5C - Pairwise estimates of $\mathrm{F}_{S T}$ (below diagonal) and closest geographic distances (Km) (above diagonal) between three geographic populations of $S$. heathii s.l..

\begin{tabular}{|l|c|c|c|}
\hline & $\begin{array}{l}\text { Indian Subcontinent } \\
\text { (Pakistan + India) }\end{array}$ & $\begin{array}{l}\text { Northern } \\
\text { Indochina }\end{array}$ & $\begin{array}{l}\text { Southern } \\
\text { Indochina }\end{array}$ \\
\hline $\begin{array}{l}\text { Indian Subcontinent } \\
\text { (Pakistan + India) }\end{array}$ & & 2903 & 3116 \\
\hline Northern Indochina & $0.433^{* * *}$ & & 589 \\
\hline Southern Indochina & $0.343 * * *$ & $0.11^{* *}$ & \\
\hline
\end{tabular}

$* * *-\mathrm{p} \leq 0.001 ; * *-0.001 \leq \mathrm{p} \leq 0.05$ 
Table S6. Factor loading for two first PCs from PCA of cranial characters.

\begin{tabular}{|c|c|c|}
\hline Characters & PC 1 & PC 2 \\
\hline GSL & 0.3500 & -0.2112 \\
\hline SL & 0.3374 & -0.3527 \\
\hline CBL & 0.2997 & -0.1891 \\
\hline CCL & 0.3054 & -0.0987 \\
\hline ZB & 0.3346 & -0.2892 \\
\hline $\mathbf{C}^{\mathbf{1}} \mathbf{C}^{\mathbf{1}}$ & 0.3356 & 0.7576 \\
\hline $\mathbf{M}^{\mathbf{3}} \mathbf{M}^{\mathbf{3}}$ & 0.2881 & 0.0963 \\
\hline $\mathbf{C M}^{\mathbf{3}}$ & 0.2835 & 0.2506 \\
\hline $\mathbf{M L}^{\mathbf{n}}$ & 0.3161 & -0.1212 \\
\hline $\mathbf{C M}_{\mathbf{3}}$ & 0.3045 & 0.2030 \\
\hline Eigenvalue & 0.0106 & 0.0003 \\
\hline \% variance & 94.184 & 2.3724 \\
\hline
\end{tabular}


Table S7. Pairwise comparisons (ANOVA-tests) of morphometrics among geographical populations of $S$. heathii s.l. in Indochina. Acronyms and definitions for measurements are given in the Materials and Methods.

\begin{tabular}{|c|c|c|c|c|c|c|}
\hline \multirow[t]{2}{*}{ Character } & \multicolumn{3}{|c|}{ North VN } & \multicolumn{2}{|c|}{ Highland Central VN } & \multirow{2}{*}{\begin{tabular}{|c|} 
South Central VN \\
Cambodia \\
(Location: 19$)$
\end{tabular}} \\
\hline & $\begin{array}{c}\text { Highland Central VN } \\
\text { (Location: 18) }\end{array}$ & $\begin{array}{c}\text { South Central } \\
\text { (Location: } 21 \text { and nearby) }\end{array}$ & $\begin{array}{c}\text { Cambodia } \\
\text { (Location: 19) }\end{array}$ & $\begin{array}{c}\text { South Central } \\
\text { (Location: } 21 \text { and nearby) }\end{array}$ & $\begin{array}{c}\text { Cambodia } \\
\text { (Location: 19) }\end{array}$ & \\
\hline FA & & $* * *$ & & $* * *$ & $* * *$ & $-*$ \\
\hline Tib & & & & $* * *$ & $* * *$ & \\
\hline GSL & $-* * *$ & $* *$ & & $* * *$ & $* * *$ & \\
\hline SL & $-* * *$ & $* *$ & & $* * *$ & $* * *$ & \\
\hline CBL & $-* * *$ & $* * *$ & & $* * *$ & $* * *$ & $-*$ \\
\hline CCL & $-* * *$ & $* * *$ & & $* * *$ & $* * *$ & $-*$ \\
\hline $\mathbf{Z B}$ & $-* * *$ & $* *$ & & $* * *$ & $* * *$ & $-* *$ \\
\hline $\mathbf{C}^{1} \mathbf{C}^{1}$ & & $* * *$ & & $* *$ & & \\
\hline $\mathbf{M}^{3} \mathbf{M}^{3}$ & & $* *$ & & $* * *$ & $* *$ & \\
\hline $\mathrm{CM}^{3}$ & & $* * *$ & $* *$ & $* * *$ & $* * *$ & $-*$ \\
\hline ML & $-* *$ & $* * *$ & & $* * *$ & $* * *$ & $-*$ \\
\hline $\mathrm{CM}_{3}$ & & $* * *$ & & $* * *$ & $* *$ & $-*$ \\
\hline
\end{tabular}

Level of statistical significance: $* p<0.05, * * p<0.01, * * * p<0.001$. 

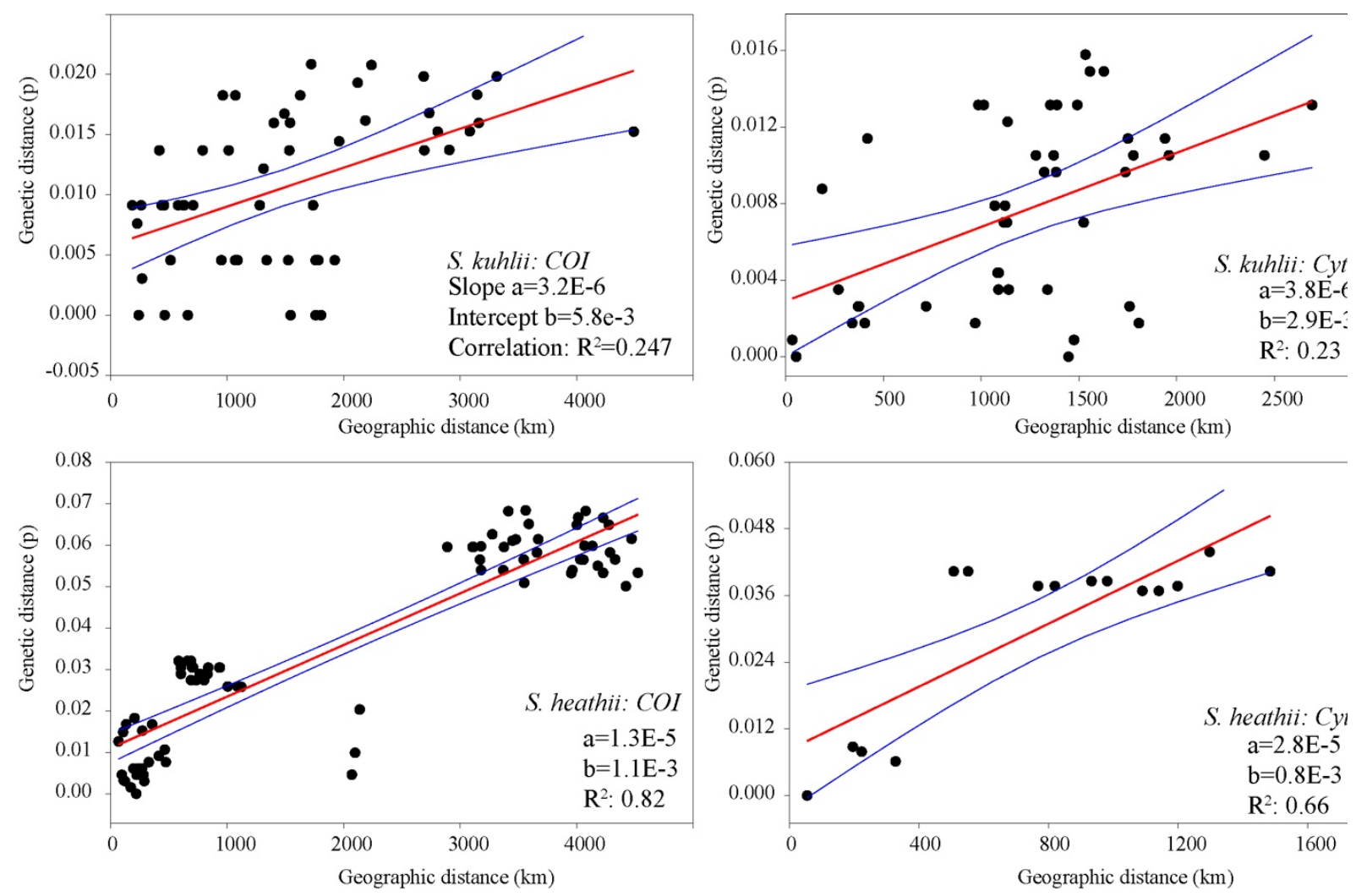

A: Correlation between pairwise genetic divergences (minimum p-distance) and geographic distance $(\mathrm{km})$ among geographic populations of Asian Scotophilus spp.

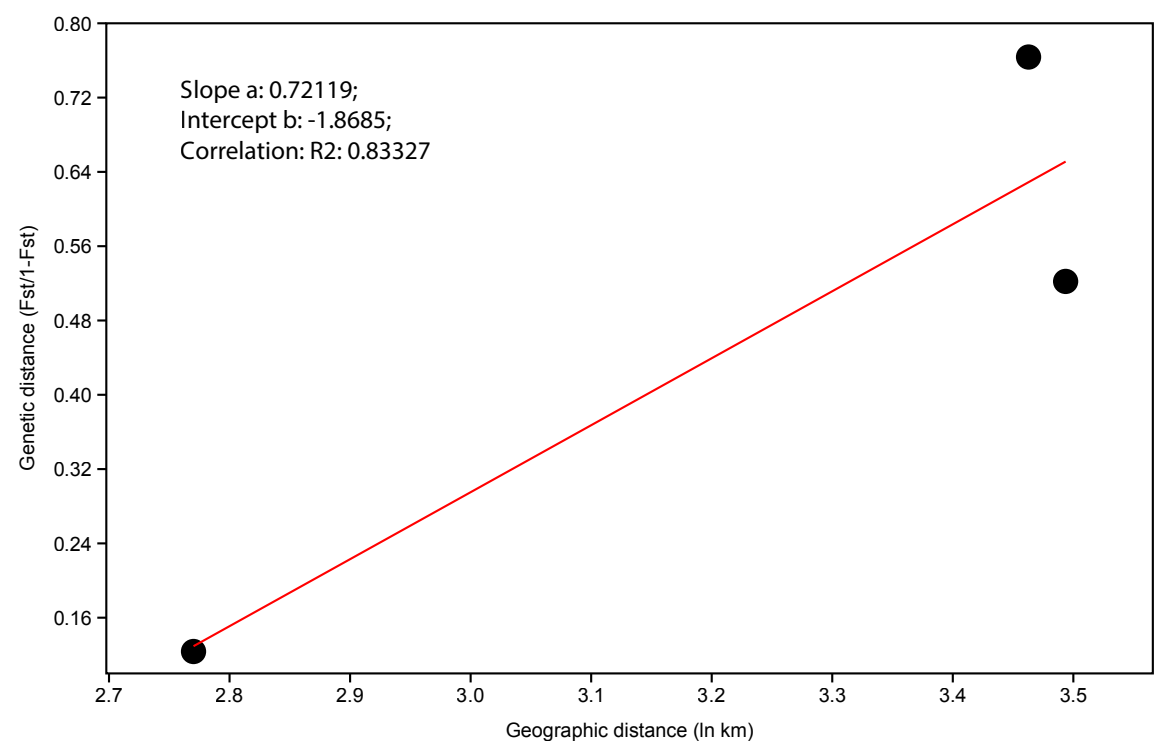

B: Correlation between pairwise genetic divergences and geographic distance among three groups of matrilines of S. heathii inferred from the COI TCS network analyses

Figure S1: Mantel tests for isolation by distance effects on pairwise genetic divergences among geographic populations of studied Scotophilus spp. 


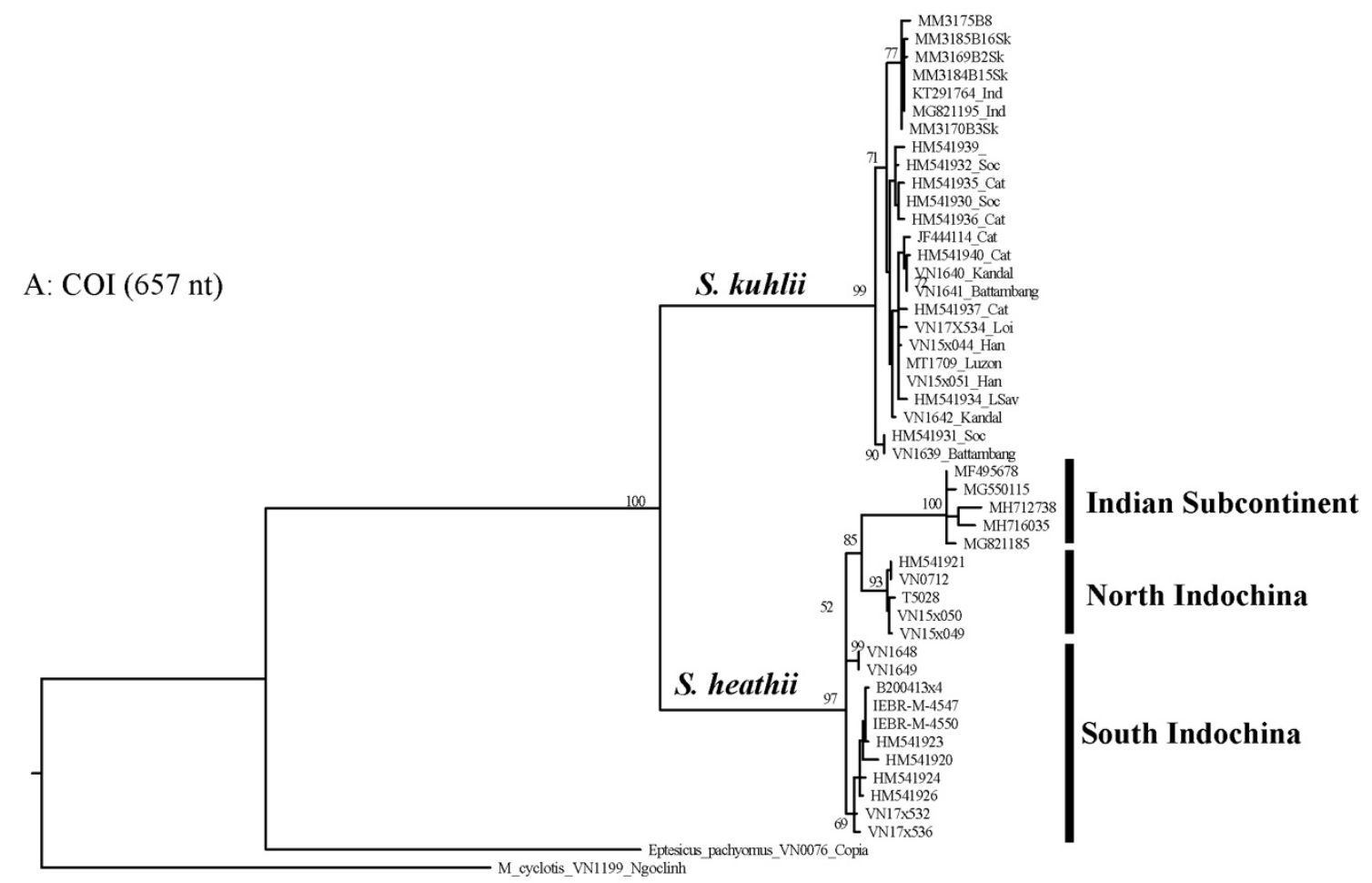

0.04

B: Cytb (1140 nt)

MM3175_Myanmar

MM3170_Myanmar

MM3298_Myanmar

MM3301_Myanmar

MM3186_Myanmar

MM3169_Myantmar
MM3302_Myanmar

41M3168_Myanmar

MM3185_Myanm

EV 7550920 Kedah

g) U750923_CatTien

Eut5026-Cartien

EU EU750927_Caftien

EU750929_SocTrang

EU750923 SocTrang

EU750922 Kedah

- EU750922_Kedah

- EU750925_CafTien

EU750931 TamDao

VN15x045 Hanoi

EU750913_Tamdao

N15x051_Hanoi

VN15x044_Hanoi

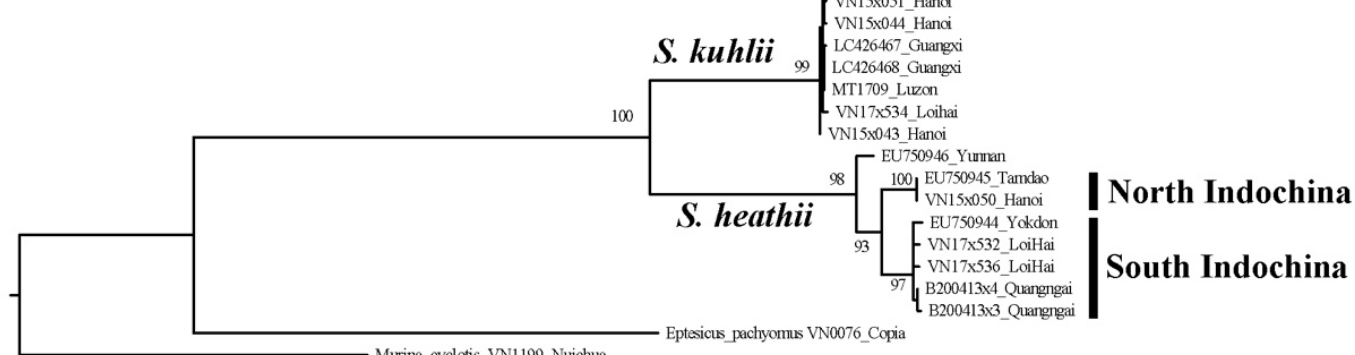

Murina cyclotis VN1199_Nuichu

0.05

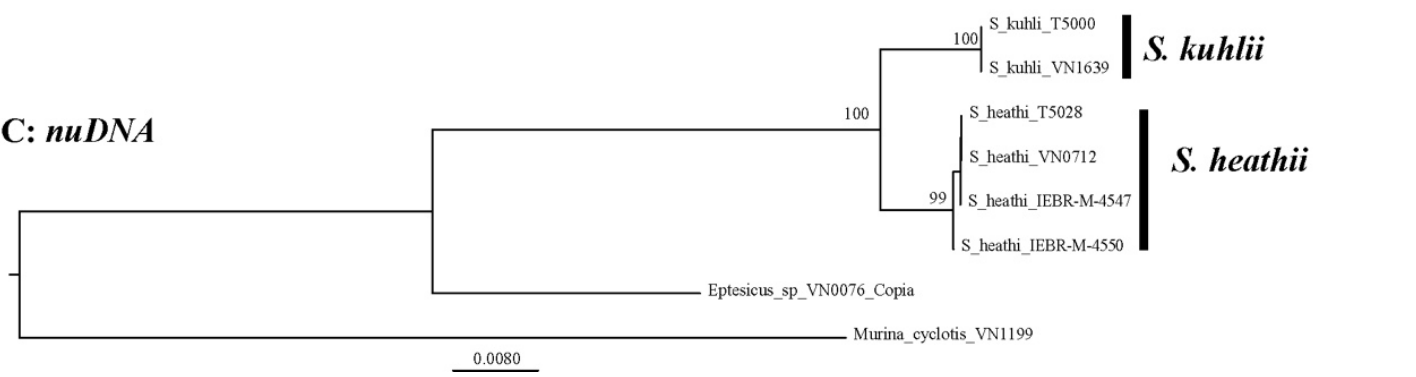

Figure S2. ML trees of Asian Scotophilus spp. and outgroups reconstructed from $C O I, C y t b$ and $n u D N A$ sequences. 

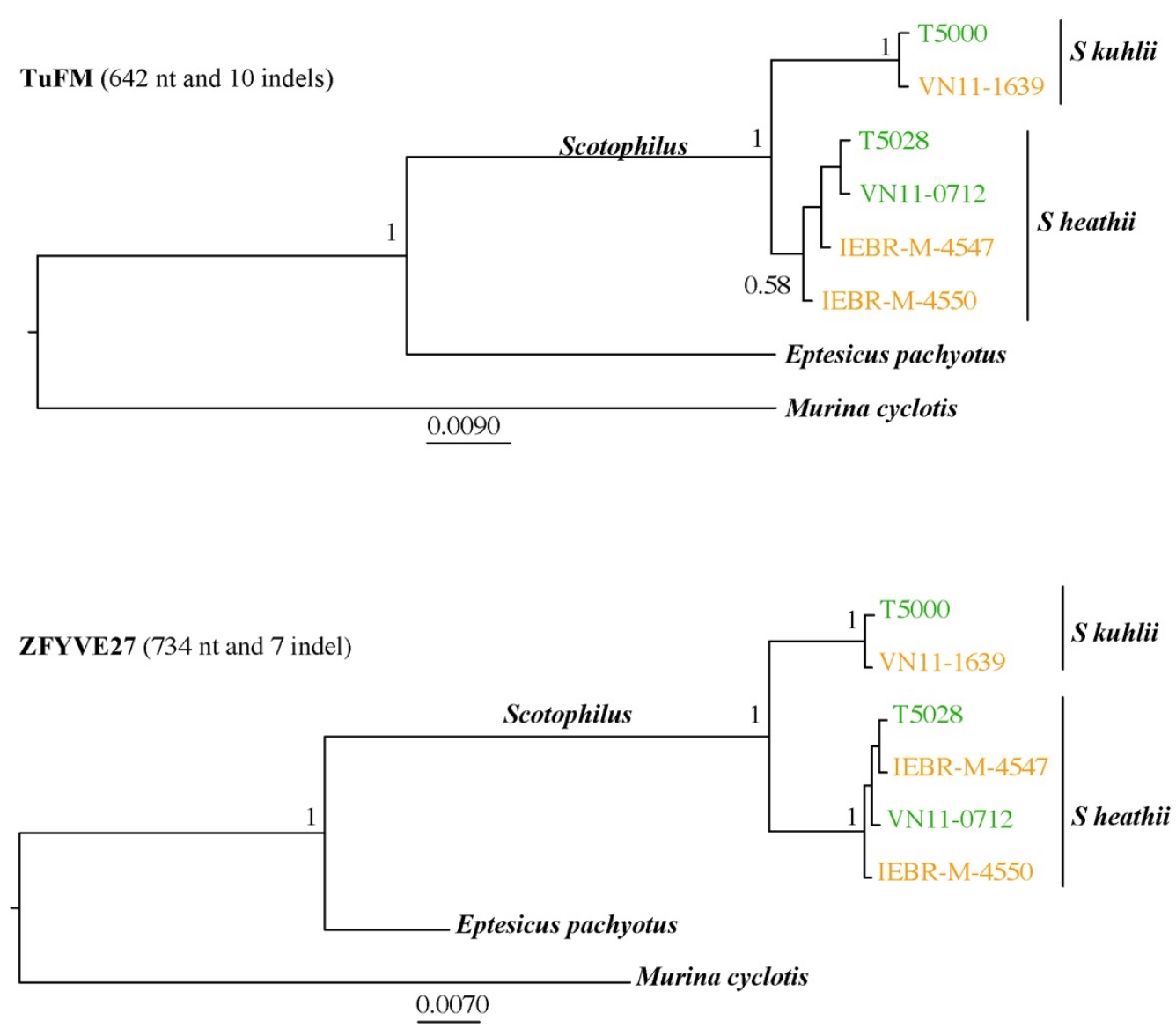

Figure S3. Bayesian trees of Asian Scotophilus spp. and outgroups reconstructed from TUFM and ZFYVE27 sequences 

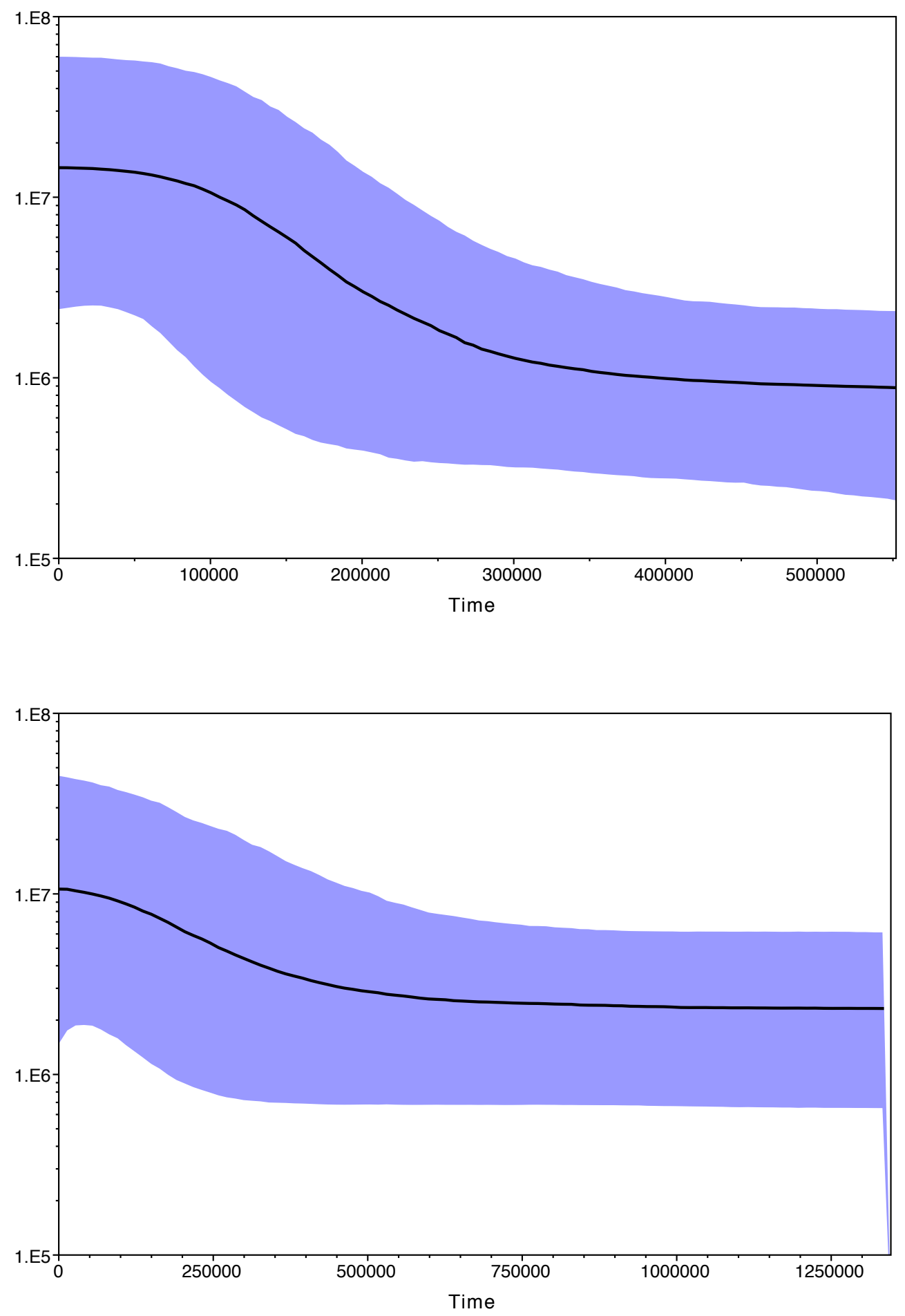

9 Figure S4. Bayesian skyline plot representing historical demographic trends in $\mathbf{S}$. $k$ uhlii 10 (above) and $S$. heathii (below). The $X$-axis presents time as years before present. The $Y$-axis 11 represents the effective female population size $(\mathrm{Ne})$. Mean estimated $\mathrm{Ne}$ represents as the 12 solid line, whereas solid intervals refer the $95 \%$ highest probability density. 


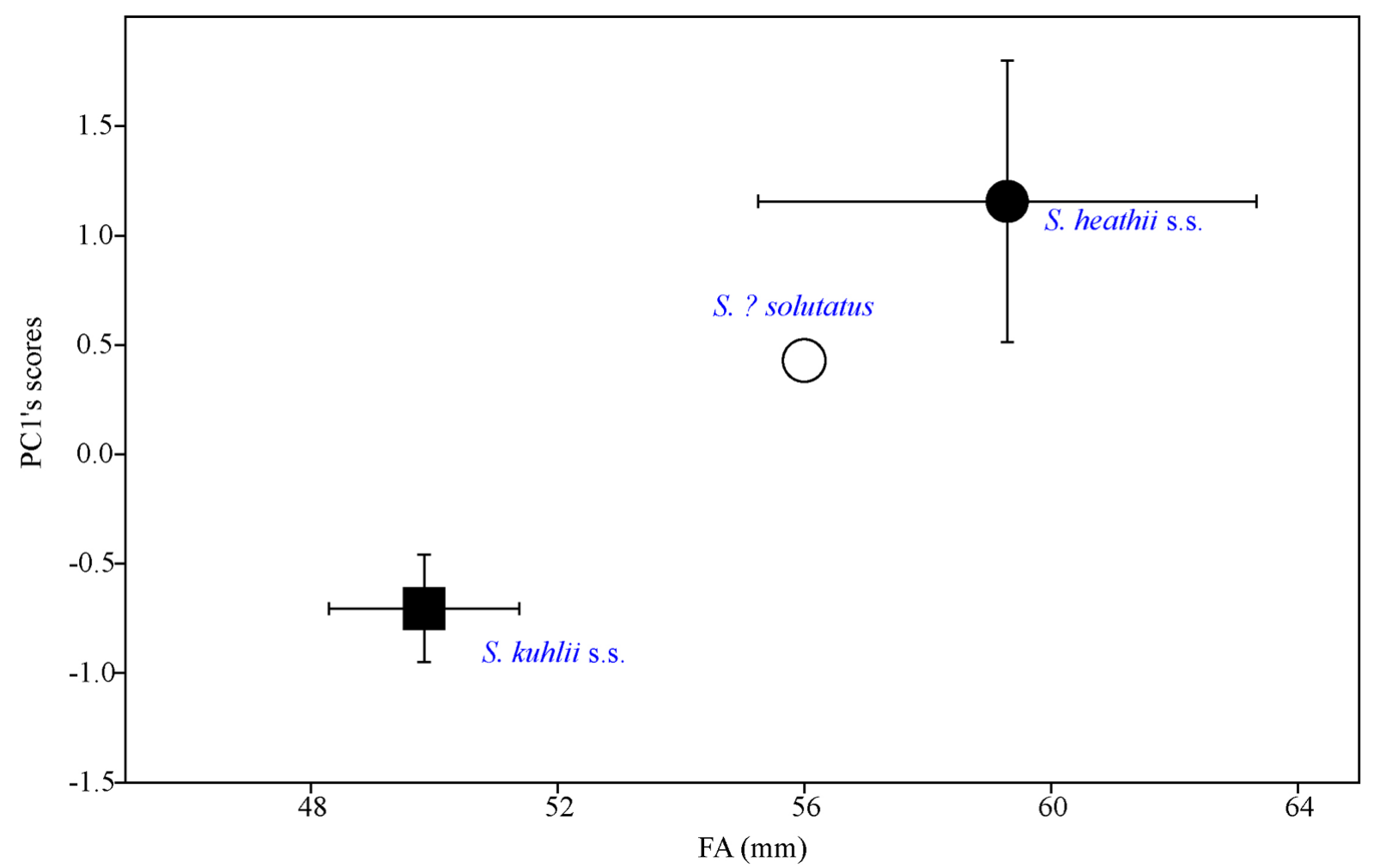

14 Figure S5. Correlation between mean values of PC1's scores obtained from PCA of skull 15 characters and FA values of Asian Scotophilus spp. 


\section{* References cited in the Supporting Information}

Allen, J. A. (1906). Mammals from the Island of Hainan, China. Bulletin of the American Museum of Natural History 22, 463-490.

Arai, S., Aoki, K., Sơn, N. T., Tú, V. T., Kikuchi, F., Kinoshita, G., ... Oishi, K. (2019). Đakrông virus, a novel mobatvirus (Hantaviridae) harbored by the Stoliczka's Asian trident bat (Aselliscus stoliczkanus) in Vietnam. Scientific Reports, 9(1), 10239. https://doi.org/10.1038/s41598-019-46697-5

Arai, S., Kang, H. J., Gu, S. H., Ohdachi, S. D., Cook, J. A., Yashina, L. N., ... Yanagihara, R. (2016). Genetic diversity of Artybash virus in the Laxmann's shrew (Sorex caecutiens). Vector Borne and Zoonotic Diseases (Larchmont, N.Y.), 16(7), 468-475. https://doi.org/10.1089/vbz.2015.1903

Blyth, E. (1851). Report on the Mammalia and more remarkable species of birds inhabiting Ceylon. Journal of Asiatic Society of Bengal 20, 153-185.

Blyth, E. (1860). Report of Curator. Journal of Asiatic Society of Bengal 29, 88.

Geoffroy I., I. (1834). Mammifères. In Voyage aux Indes-Orientales par le Nord de l'Europe, C. Bélanger, ed. (Paris: Arthur Bertrand), pp. 3-160.

Gray, J. E. (1843). List of the specimens of Mammalia in the collection of the British Museum (London: Trustees of the British Museum).

Hassanin, A., An, J., Ropiquet, A., Nguyen, T. T., \& Couloux, A. (2013). Combining multiple autosomal introns for studying shallow phylogeny and taxonomy of Laurasiatherian mammals: Application to the tribe Bovini (Cetartiodactyla, Bovidae). Molecular Phylogenetics and Evolution, 66(3), 766-775.

Horsfield, T. (1824). Zoological researches in Java, and the neighbouring islands (London: Printed for Kingsbury, Parbury, \& Allen).

Horsfield, T. (1831). Observations on two species of bats, from Madras, one of them new, presented by Mr. Heath. Proc. Comm. Zool. Soc. London Part I, 113-125.

Horsfield, T. (1851). A catalogue of the Mammalia in the Museum of the Hon. East-India Company (London: J. \& H. Cox).

Ikram,A., Javed,A., Mansoor,S., Nazir, S., \& Hayat, M. Q. (Unpublished). Barcoding of bats of Pakistan.

Irwin, D. M., Kocher, T. D., \& Wilson, A. C. (1991). Evolution of the cytochrome b gene of mammals. Journal of Molecular Evolution, 32(2), 128-144. Arai, S., Aoki, K., Son, 
N. T., Tú, V. T., Kikuchi, F., Kinoshita, G., ... Oishi, K. (2019). Đakrông virus, a novel mobatvirus (Hantaviridae) harbored by the Stoliczka's Asian trident bat (Aselliscus stoliczkanus) in Vietnam. Scientific Reports, 9(1), 10239. https://doi.org/10.1038/s41598-019-46697-5

Kloss, C. B. (1917). On five new mammals from Siam. Journal of the Natural History Society of Siam 2, 282-287.

Kruskop, S. V., Eger, J. L., Lim, B. K., Engstrom, M. D., Francis, C. M., Guillen Servent, A., Ivanova, N. V., \& Borisenko, A. V (Unpublished). Bats of Southeast Asia, Part 2.

Leach, W. E. (1821). The characters of three new genera of bats without foliaceous appendages to the nose. Transactions of the Linnean Society of London 13, 73-82.

Rahman, A. \& Choudhury, P. (Unpublished). Sequencing and analysis of $12 \mathrm{~S}$ ribosomal RNA gene, 16S ribosomal RNA gene and cytochrome oxidase gene of different species of bats of Cachar district, Assam

Sody, H. J. V. (1928). Twee nieuwe subspecies van Pachyotis temmincki Horsf. Natuurkundig Tijdschrift Voor Nederlandsch Indië 88, 86-91.

Sody, H. J. V. (1936). Seventeen new generic specific, and subspecific names for Dutch East Indian mammals. Natuurkundig Tijdschrift Voor Nederlandsch-Indie 96, 42-55.

Srinivasulu, C., Bhargavi, S., Aditya, S., Tariq, A. S., \& Devender, G.* (Unpublished). Barcoding bats of peninsular India including Andaman and Nicobar Islands.

Tan, Z., Gonzalez, G., Sheng, J., Wu, J., Zhang, F., Xu, L., Zhang, P., Zhu, A., Qu, Y., Tu, C., Carr, M. J., \& He, B. (2020). Extensive genetic diversity of Polyomaviruses in sympatric bat communities: Host switching versus coevolution. Journal of Virology, 94(9), e02101-19, /jvi/94/9/JVI.02101-19.atom. https://doi.org/10.1128/JVI.02101-19

Thomas, O. (1897). On some bats obtained in the Surat and Thana districts by Mr R. C. Wroughton. Journal of the Bombay Natural History Society 11, 274-276.

Tu, V. T., Cornette, R., Utge, J., \& Hassanin, A. (2015). First records of Murina lorelieae (Chiroptera: Vespertilionidae) from Vietnam. Mammalia, 79(2), 201-213. https://doi.org/10.1515/mammalia-2013-0101 